\title{
Cyclicity and hierarchy in sequence stratigraphy: an integrated approach
}

\author{
Daniel Galvão Carnier Fragoso ${ }^{1,2 *}$ (D), Guilherme Pederneiras Raja Gabaglia' (D, \\ Antonio Jorge Campos Magalhães $3,4,5$ (D), Claiton Marlon dos Santos Scherer ${ }^{2}$ (D)
}

\begin{abstract}
With standardized methodology and nomenclature, the sequence stratigraphy aims to characterize multi-scale cyclical units of genetically related rocks into a hierarchical chronostratigraphic framework. From facies to basin scale, the stacking patterns and stratigraphic surfaces are recognized as sequence elements. In parallel, Earth sciences have developed a sophisticated understanding of geological processes (tectonic, climatic, and eustatic) that produce the main cyclicity observed in the sedimentary rock record. This review paper discusses how the elaboration of hierarchical stratigraphic frameworks that incorporate the knowledge of these periodic geological processes - from high- to low-frequencies - as the control of generation and preservation of sequences - from high- to low-resolutions - guarantees objective results in predicting vertical recurrence and the lateral correlation of genetic stratigraphic units. This interpretive approach of cyclic stratigraphic analysis supports the development of effective observable criteria to identify and rank sequences in multiple scales, based on cycle anatomy, recurrence, vertical trends, and mappability. This methodological improvement reduces the inaccuracies and contradictions of traditional conceptual models based on fully preserved three-dimensional depositional systems.
\end{abstract}

KEYWORDS: sequence stratigraphy; cyclicity; hierarchy.

\section{INTRODUCTION}

Since the definition of "sequence" was provided by Sloss et al. (1949), a significant theoretical and technological evolution allowed the formulation of sequence stratigraphy in the current terms (e.g.) Sloss 1963, Mitchum 1977, Johnson and Murphy 1984, Posamentier et al. 1988, Van Wagoner et al. 1988, Galloway 1989, Embry and Johannessen 1992, Hunt and Tucker 1992, Catuneanu et al.2011). Due to its academic scope and industrial applicability, sequence stratigraphy is recognized as the primary research program for stratigraphic analysis. The contributions in recent years have promoted the standardization of methodology and nomenclature (Catuneanu et al. 2010, 2011). Its modern application offers powerful tools for describing the observable record from facies cycle to basin scale, through the definition of sequences within a

\footnotetext{
${ }^{1}$ Petrobras - Rio de Janeiro (RJ), Brazil. E-mails: galgeo@gmail.com, guilhermeraja@petrobras.com.br

${ }^{2}$ Instituto de Geociências, Universidade Federal do Rio Grande do Sul Porto Alegre (RS), Brazil. E-mail: claiton.scherer@ufrgs.br

${ }^{3}$ Faculdade de Ciências, Instituto Dom Luiz, Universidade de Lisboa Lisboa, Portugal.E-mail: jmagalbr@gmail.com

${ }^{4}$ Programa de Pós-Graduação em Geodinâmica e Geofísica, Universidade Federal do Rio Grande do Norte - Natal (RN), Brazil.

${ }^{5}$ China-Brazil Joint Geoscience Research Center IGGCAS - China.

${ }^{*}$ Corresponding author.
}

C) 2021 The authors. This is an open access article distributed under the terms of the Creative Commons license. hierarchical chronostratigraphic framework (e.g., Catuneanu 2019a). Notably, the sequential analysis on the outcrop scale has received special attention from the scientific community, increasingly improving what is known as high-resolution stratigraphy (e.g., Magalhães et al. 2020).

During the last centuries, precursor and complementary research lines to sequence stratigraphy, that investigate the external and internal dynamics of the planet, provided a sophisticated comprehension of periodic eustatic, tectonic, and climatic processes, and their respective cyclical records observed in sedimentary sections. Thus, while sequence stratigraphy aims to identify and correlate cycles of genetically related rocks in the stratigraphic record, the study of geological processes contributes to elaborating robust conceptual models, which control the spatial and temporal distribution of sedimentary units. Such integrated solutions are critical, for example, for the evolution of modern three-dimensional stratigraphic-sedimentological forward modeling (e.g., Faria et al. 2017).

However, aiming to universalize its application, recent publications have assigned to sequence stratigraphy a descriptive emphasis, based on the observation of stratal stacking patterns in the rock record, disassociating the methodology from the underlying sedimentary controls (e.g., Catuneanu and Zecchin 2013, Catuneanu 2019a, 2019b). Although the segregation between description and subsequent interpretation seems prudent for practical functionality, it is crucial to keep in mind that, in a geological investigation, geologists do not always find completely objective data or information "purely given", but the way they analyze the record is always shaped by previous conceptions, 
expectations, and values (Frodeman 1995). In this sense, does the revised and updated knowledge about the geological processes that control sedimentation and, especially, the preservation of the sedimentary record have no role in developing the sequence stratigraphy workflow and methodology?

This paper is a review based on more than two decades of successful experience of the Petrobras School of High-Resolution Stratigraphy developed in cooperation with researchers from Brazilian and international universities, bringing together some relevant works produced on the subject. Following the concepts of sequence stratigraphy, the objective is to present: A brief conceptual discussion on the fundamental importance of preserving the cyclical sedimentary record in paleoenvironmental reconstructions; The main cyclic controls of sedimentary deposits that derive from periodic eustatic, tectonic, and climatic processes; The methodological advantages of integrating the most up-to-date knowledge of cyclic controls on sedimentation in defining a predictive logic that supports the identification of low- and high-resolution sequences organized in a hierarchical framework.

\section{PHILOSOPHICAL FOUNDATION}

\section{The interdependence between description and interpretation in sequence stratigraphy}

Sequences were originally designed to define stratigraphic units bounded by unconformities, mapped on continental scales "greater than the hierarchy of group or supergroup" (Sloss et al. 1949, Sloss 1963). Later, this definition was incorporated in seismic interpretation to outline smaller scale units (Vail 1992, Dott 2014). In this adaptation, the seismic recognition of sequences considered both subaerial unconformities and their marine extensions of correlative conformities (Mitchum 1977).

From 1970 to 1990, different proposals for definitions and models of sequences produced a profusion of propositions and jargon in the literature (Catuneanu 2006). Among some reasons for the origin of such a diversity of models are the use of different databases, the different sedimentary and geotectonic contexts, and the premises on primary sedimentation controls (Catuneanu 2006). Despite these differences, all models have been linked to base-level changes, and presented stratigraphic surfaces as the essential descriptive criterion in defining sequences (Fig. 1).

After the 2000s, methods and terms in sequence stratigraphy analysis were standardized (Miall 2016). In this context, Catuneanu et al. (2009, p. 19) defined a sequence as "a succession of strata deposited during a full cycle of changes in accommodation or sedimentary supply". This generic, yet advanced definition is independent of temporal and spatial scales and suitable for all previously proposed sequence models. However, despite its full acceptance by the community (e.g., Catuneanu et al. 2011), this definition presented a possible weakness, once it did not offer objective criteria to describe sequences from a real dataset. Thus, Catuneanu and Zecchin (2013, p. 27) presented a revised definition of a sequence as "a cycle of change in stratal stacking patterns, dividable into systems tracts and bounded by sequence stratigraphic surfaces".

Catuneanu and Zecchin (2013), Catuneanu (2019a, 2019b) advocate that the concepts and methodology of sequence stratigraphy must be focused on observational field criteria of stratal stacking patterns in the rock record, regardless of the interpretation of the primary controls on sequence development. The main argument of these authors is that most elements of the sequences can be developed similarly as a product of different sedimentary processes. Thus, although the interpretation of the underlying controls may be at the base of the elaboration of a stratigraphic sequence framework, it "plays no role in the sequence stratigraphic workflow and methodology" (Catuneanu 2019a, p. 314).

Dissociation of accurate description from the subsequent interpretation seems prudent when so many variables are involved in building the stratigraphic record. For this reason, the definition of a sequence proposed by Catuneanu and Zecchin (2013) is valid and opportune. Keeping the methodology focused on observational field criteria is an advantage for stratigraphic sequence nomenclature and methodology. However, observation in geology differs substantially from other sciences that have an experimental and analytical basis (Fantinel 2005). Due to the complexity of the spatial and temporal scales involved in the stratigraphic investigation, one of the most significant methodological challenges is to give meaning to both the sedimentary record and the gaps (e.g., Miall 2017). In this way, geologists are forced to fill in the gaps with reasonable interpretations (Frodeman 1995).

According to Catuneanu (2019a), the shoreline trajectory is a key element for describing progradation and retrogradation stacking patterns and associated systems tracts in downstream-controlled areas. However, the paleoenvironmental reconstruction, which determines transgressions and regressions at each stage of shoreline trajectory changes, is systematically and vertically interrupted by every non-gradual contact of the sedimentary succession. In this sense, the definition of stacking patterns, which is a basic descriptive task in the sequence stratigraphy practice, depends on the ability of geologists to properly bind the various interpreted paleoenvironmental fragments by assigning meaning to the gaps in the record (see item "General Problem on Conceptual Depositional System"). This is an elementary example of how the geological methodology, although based on well-defined descriptive criteria, will always have some subjectivity and dependence on interpretation.

The crucial point here is, instead of enhancing the antagonism, to propose a complementary view to rescue the simultaneous descriptive and interpretive approaches in sequence stratigraphy. In other words, the best definition of descriptive criteria for any stratigraphic framework results from the interpretation of how their respective organization could be developed (and vice versa). It is a dynamic dependency that does not end in the visualization of the geological record itself, but continues in a spiral between the descriptive experience and the interpretation, through the contact with new knowledge, new investigative contexts, and further investigation tools (Fantinel 2005). This approach does not weaken the 


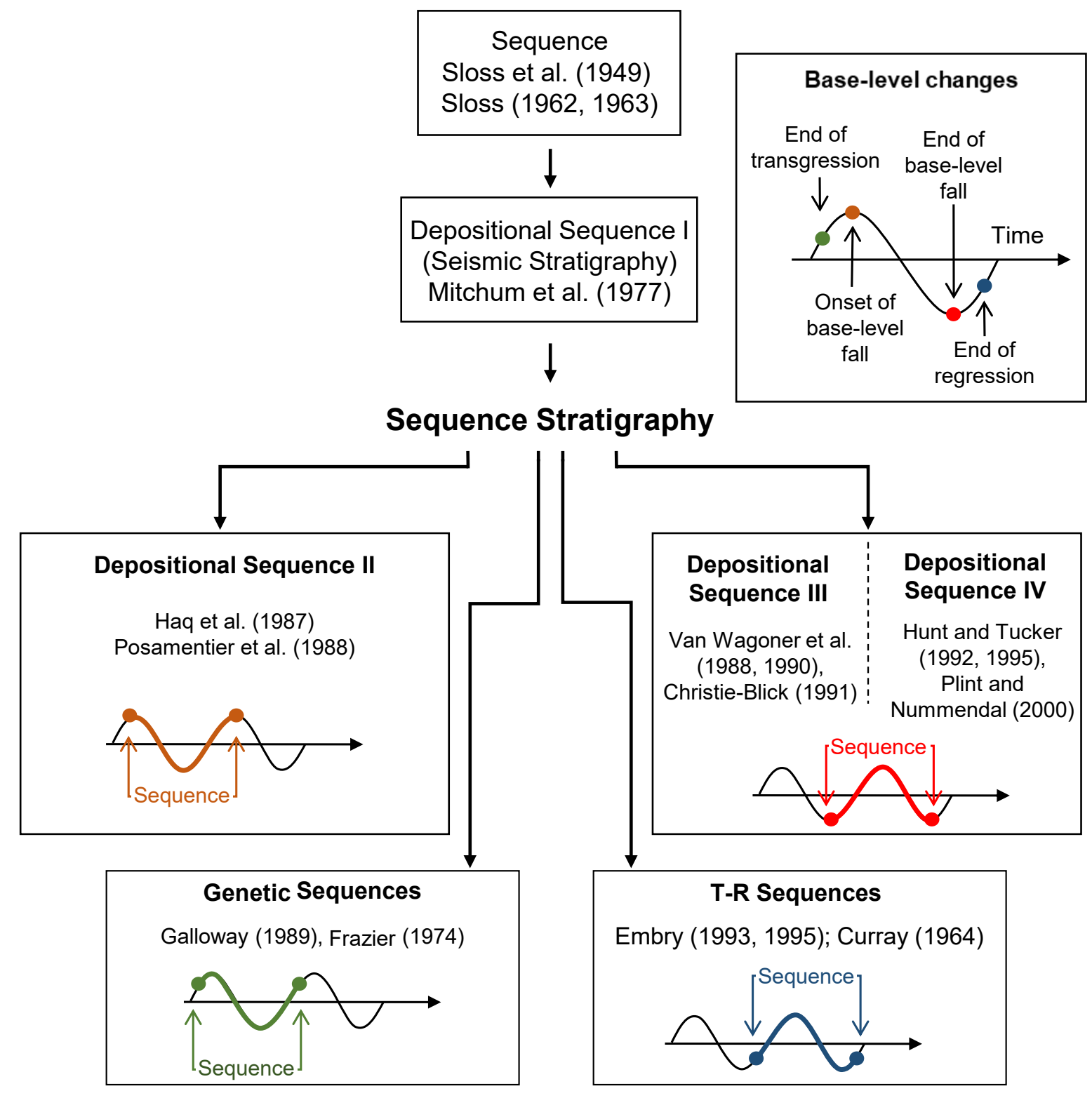

Depositional Sequence: Limited by subaerial unconformities and their marine correlative concordances Genetic Sequences: Limited by maximum flood surfaces.

T-R Sequences: Limited by composite surfaces that includes by subaerial unconformities and the marine portion of the maximum regression surface.

Source: modified from Catuneanu (2006).

Figure 1. Historical evolution of sequence stratigraphy models (modified from Catuneanu 2006). The nature of the separation of depositional sequence models III and IV is only semantic, relative to the systems tracts' distinct nomenclature with identical sequence limits.

observational field criteria on sequence stratigraphy analyses. On the contrary, the interpretative proposal advocated here associates the fundamental concepts of sequence stratigraphy (see item "Conceptual Foundation") with updated knowledge of periodic geological processes that control sedimentation, and especially, the preservation of the cyclical sedimentary record (see item "Allogenic Sequence-Generating Mechanisms"). This approach helps to define a predictive logic that supports improvements in the workflow and in the methodology of sequence stratigraphy at all scales permitted by the available data (see item "Sequence Hierarchy").
General problem on conceptual depositional system: the "Frankenstein models" vs. the preservation of cyclical sedimentary record

It is common sense that the hiatuses encompass much more time than the sedimentary rock record (e.g., Dott 1983, Ager 1993, Miall 2017). According to Barrell (1917), the recurrent pattern of stratigraphic organization, which includes the rock record and the gaps, is a product of the rise and fall, in multiple amplitudes and frequencies, of the base level (Fig. 2). In this sense, the preserved sedimentary record corresponds to a tiny 
Time intervals recorded by sedimentation

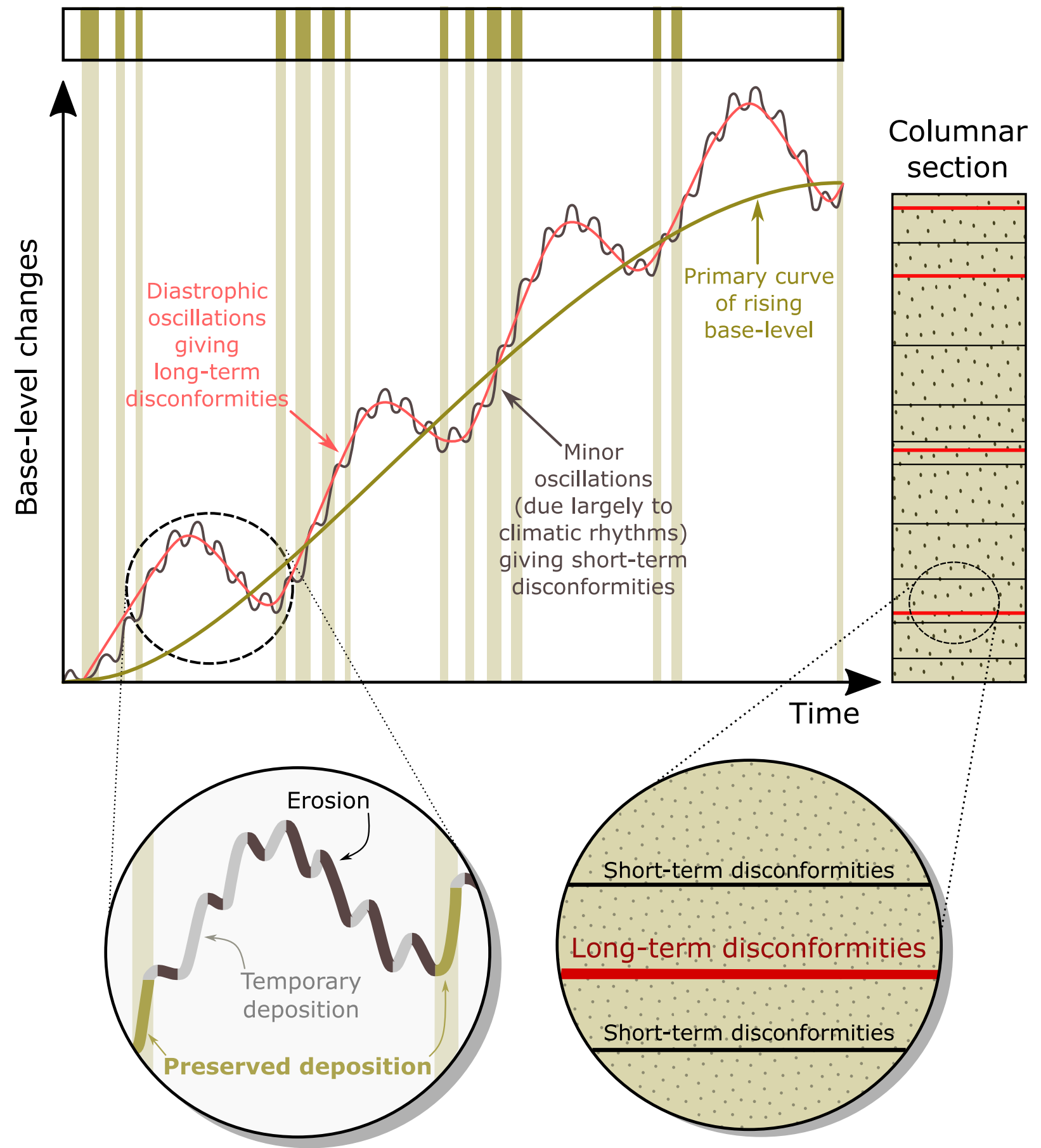

Source: modified from Barrell (1917).

Figure 2. Graph represents the sedimentary stacking as a product of harmonic fluctuations of multiple frequencies of base-level changes. In this view, the low preservation of deposits (only one-sixth of the time) results in large gaps (unrecorded time is shown in the upper portion of the figure) and materialized as surfaces in the record.

fraction of the geological time, and its completeness is a function of the observation scale, whose control deteriorates as short as timescales (increased resolution) are considered (Sadler 1999).

Given the lack of tools or parameters for measuring so many time gaps, which are defined by high-resolution analysis, conceptual sedimentary models are traditionally elaborated from a controversial uniformitarian point of view. Thus, models are built based on the assumption that observations made on short time scales, accessible to human observation, can be reliably compared with sedimentary records that represent very long-time intervals (Miall 2015). Consequently, it is assumed that the geographic arrangement of architectural elements can represent fully preserved three-dimensional depositional systems. However, analyzing the shoreline shifts during the last glacial period ( $\sim 20,000$ years ago, Fig. 3$)$ it is clear to deduce how sedimentary environments are ephemeral and susceptible to significant transformations.

Both the generation and preservation of sedimentary deposits in the stratigraphic record are dependent on processes operating during base-level fluctuations, promoting 

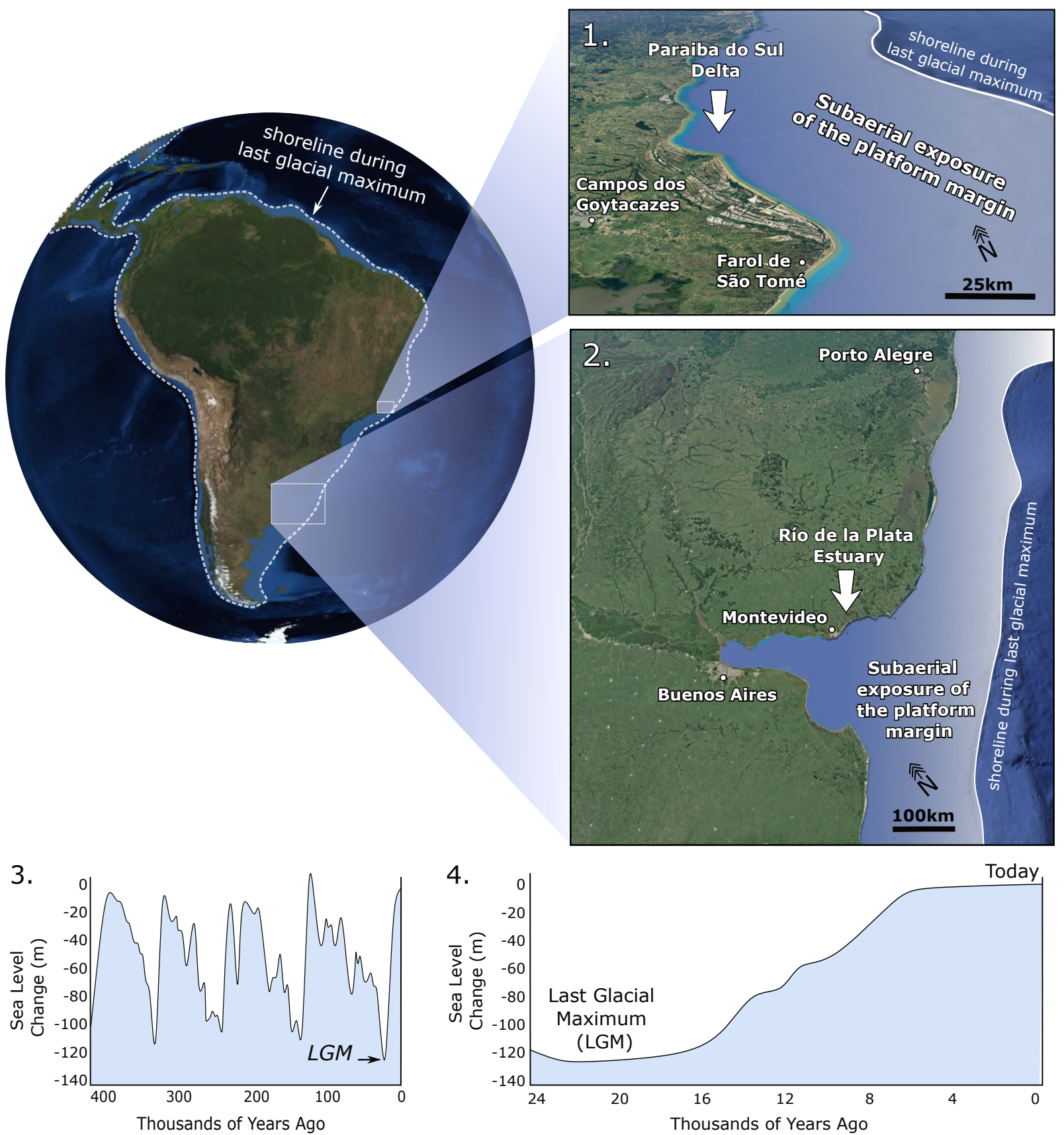

Figure 3. Simplified representation of the shoreline's mean position and the continental platform exposed in South America during the last glacial maximum (LGM) (based on Gautney 2018). Examples of modern environments, and indications of the approximate location of the shoreline during the LGM: (1) Delta of Parnaíba do Sul (State of Rio de Janeiro, Brazil); (2) Estuary of the Rio de la Plata (between Argentina and Uruguay). Below are models for the global variation in sea level over the past 400,000 (3 from Waelbroeck et al. 2002) and 24,000 years (4 from Wright et al. 2020).

the high-frequency overlap of different paleogeographies (e.g., Magalhães et al. 2016, Silveira 2020). Such an alternation prevents the complete and idealized distribution of sedimentary environments in the geological record, limiting the application of Wather's law. Consequently, due to the inconsistencies in making the principle of actualism compatible with long-term processes, "Frankenstein Models" are proposed. "Frankenstein Models" is considered here as the unrealistic simplification of the geological record based on fragmentary information belonging to different geographic and temporal realities, usually alternating, and mistakenly assembled in supposedly complete depositional systems, developed, and preserved by a continuous process of sedimentation (Fig. 4).

To guarantee more realistic representations, conceptual models must incorporate the principles of high-frequency paleogeographic evolution, in which both the gaps and the preserved record occur in predictable and orderly stratigraphic patterns (Fig. 4) at all time scales (Miall 2017). Thus, the classical sedimentary approaches inherited from the lithostratigraphy, used in regional geological mapping, and the interpretation of sequences restricted to the seismic scale (low-resolution) need to be systematically revised. These large (low-resolution) mappable units usually brought together into "Frankenstein Models" 


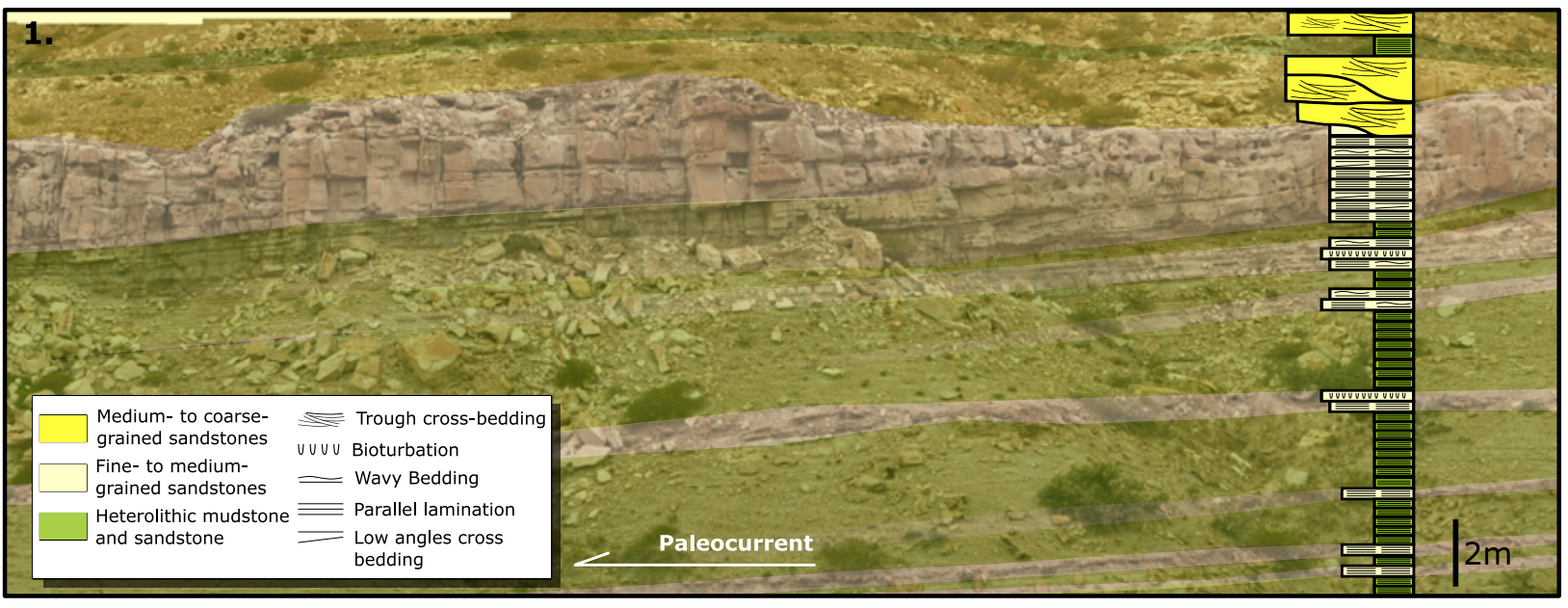

2. "Frankenstein model" of depositional systems
Conceptual model based on a wholly preserved

three-dimensional delta system.

This model connects all sedimentary facies observed along a vertical section in a single paleogeography.

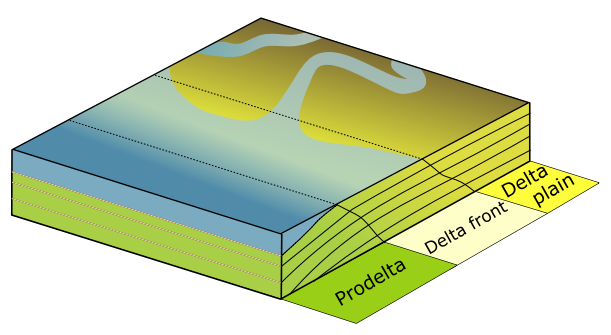

\section{Stratigraphic surfaces:}

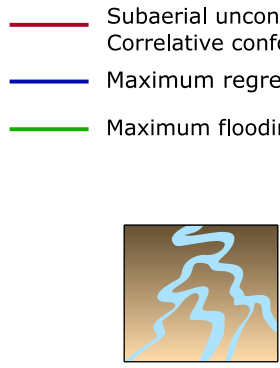

Delta plain

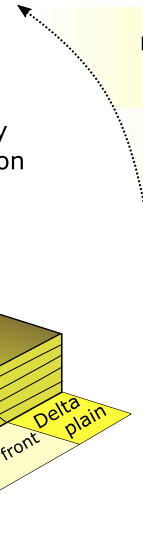

Shoreline trajectory:

$\checkmark$ Regression

Transgression
VS. 3. High-resolution sequence stratigraphic model

Conceptual model based on changes in paleogeography, limited by stratigraphic surfaces, due to high-frequency fluctuations of the relative sea-level (based on Silveira, 2020).

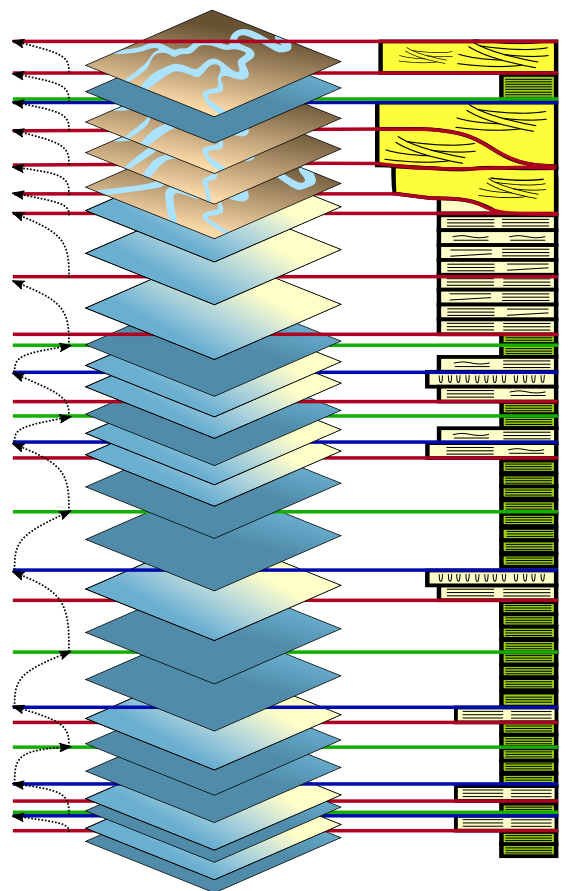

In addition to facies, stacking patterns and sedimentary surfaces are incorporated into the interpretation of high-frequency depositional cyclicality and the gaps.

Figure 4. Difference between paleoenvironmental reconstructions of the same stratigraphic data: (1) Interpreted section of the Lajas Formation (Jurassic of Neuquen Basin, Argentina), showing prograding deltaic clinoform, including sedimentary log; (2) "Frankenstein model", based on fragmentary information mistakenly assembled in a wholly preserved three-dimensional depositional system; (3) the interpretation elaborated by the concepts of sequence stratigraphy, which considers both cyclic deposition and the gaps (example based on Silveira 2020).

are nothing more than the materialization of high-frequency trends during the evolution of long-term cyclic processes.

\section{CONCEPTUAL FOUNDATION}

\section{Autogenic and allogenic processes}

Autogenic and allogenic processes describe the controls of sedimentary dynamics. Autogenic processes are produced by the natural distribution of energy and sediments promoted by the intrinsic dynamics of the depositional environments. The occurrence of these processes is either quasi-periodic or episodic. Channel migration, lateral avulsion of delta lobes, and catastrophic sedimentary events are examples of autogenic dynamics. Such processes are commonly studied by conventional sedimentology of facies analysis and physical and numerical modeling (e.g., Fick et al. 2017).

Allogenic processes correspond to forces external to the sedimentary environments, traditionally related to climatic, eustatic, and tectonic dynamics (see item "Allogenic 
Sequence-Generating Mechanisms"). The effect of such processes represents the main control on accommodation (see item "Accommodation and Preservation") over large portions of a sedimentary basin, which supports stratigraphic correlations by depositional trends (Catuneanu 2006, Miall 2010, Catuneanu et al. 2011).

Distinguishing the record of these processes has been a matter of great discussion (e.g., Trampush et al. 2017, Hajek and Straub 2017). Part of this discussion should consider how a given factor, alone or interactively, interferes with sedimentation and may influence the energy distribution of a given depositional system. Some authors argue that independent autogenic or allogenic effects may produce similar elements of sequences that characterize the anatomy of the sequence, such as stacking patterns and respective stratigraphic surfaces (e.g., Catuneanu and Zecchin 2013). However, Schwarzacher (2000, p. 61) emphasized that "the practice of classifying the repetitive sediment sequences as 'autocyclic', without identifying a proper mechanism which causes the observed cyclicity, is highly unsatisfactory".

The repetition of allogenic processes is key for the comprehension of the stratigraphic framework based on regular and hierarchical patterns (Holbrook and Miall 2020). Thus, although the autogenic processes are inherent to the formation of any sedimentary succession (Hajek and Straub 2017), the knowledge about the frequency of allogenic processes provides essential prediction to sequence stratigraphy paradigms (e.g., Shanley and McCabe 1994, Miall 2015).

\section{Sedimentary supply and sedimentation rate}

Any stratigraphic record can be described by its facies and sedimentary surfaces. In the final analysis, every sedimentary surface represents non-recorded time (Ager 1993). In turn, sedimentary facies correspond to the preserved product of erosion, transport, and depositional processes (e.g., Schumm 1977, Reading and Levell 1996, Allen 2008). Sedimentary supply corresponds to the influx of sedimentary particles and solutes into the basin. The sedimentation rate varies by many orders of magnitude and may concern extrabasinal (allochthonous) or intrabasinal (autochthonous) sediment origin.

The extrabasinal sedimentary supply is linked to the production and distribution of terrestrial material. Sediment supply variation over time is closely related to continuous or catastrophic autogenic processes (e.g., Einsele and Seilacher 1982, Dott 1983, Reading and Levell 1996). Nevertheless, allogenic influence can also affect sediment supply, such as tectonic processes in the source area and climatic variations (e.g., Castelltort and Van Den Driessche 2003, Miall 2016, Romans et al. 2016).

The intrabasinal sedimentary supply can be produced by chemical, biochemical, and biological processes. The production of marine and lake carbonate and evaporite, for example, is mainly controlled by water geochemistry and temperature, influencing the nature and the productivity of the biota (e.g., Reading and Levell 1996). Recycling is also in charge of the intrabasinal sedimentary supply, responsible for transporting particles between different domains of the basin (e.g., Auchter et al. 2020).

Unlike sedimentary supply, which refers to the deposition process, the sedimentation rate is determined from the preserved accumulation. Therefore, estimates of sedimentation rates depend on the magnitude of the analyzed stratigraphic intervals (e.g., Sadler 1999, Schlager, 2004, 2005, 2010, Miall 2015). Regardless of the depositional context, sedimentation rates systematically decrease with the increased analyzed time intervals (Sadler 1999; Fig. 5.1). In other words, the longer the measured time interval, the lower the sedimentation rate, since in very long stratigraphic intervals, several gaps are added to the time of deposition (Schlager 2005; Fig. 5.2). In this
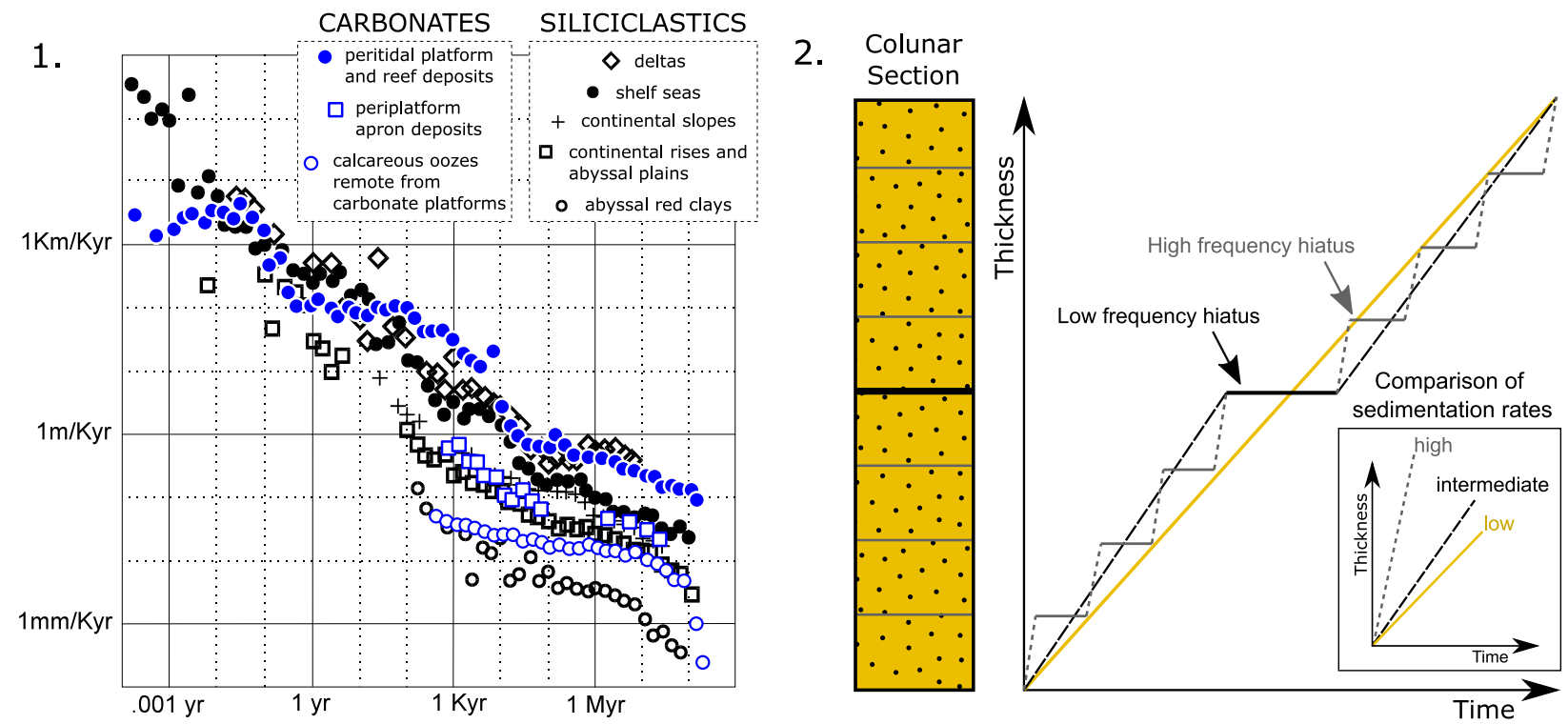

Figure 5. Sedimentation rates as a function of time intervals: (1) Mean accumulation rates for siliciclastic and carbonate sediments empirically determined as a function of time intervals (modified from Sadler 1999); (2) Schematic graph of time $\mathrm{x}$ stratigraphic thickness indicating how the calculated sedimentation rates are dependent on the length of the analyzed intervals between gaps (based on Schlager 2005). 
sense, although it is possible to differentiate sedimentation from sediment supply and sedimentation rates, to analyze the stratigraphic record, it is essential to understand the controls of preservation at different scales using the variations in accommodation over geological time.

\section{Accommodation and preservation}

Jervey (1988) originally defined accommodation as the space below the base level (above which erosion will occur) available for sediments to fill. According to Jervey (1988), the base level is controlled by the sea, and, ultimately, is equivalent to the sea level. Although this accommodation concept is most used in sequence stratigraphy, some authors emphasize the need for improvements.

Muto and Steel (2000) proposed accommodation as "thickness, measured at a specified site and time, of a space which becomes filled with sediments during a specified time interval" (Fig. 6). In this sense, accommodation is treated objectively as a result rather than a potential. Exclusively in subaqueous environments, the "potential accommodation" can be analyzed in relation to the lateral paleogeographic variations over the same time interval, considering the bathymetry (Muto and Streel 2000; Fig. 7). In this sense, at a given time (correlatable stratigraphic interval), it is possible to assess, for example, that the "potential accommodation" is more significant in the center of any subaqueous environment than in its margins.

Accommodation variations can be described as relative (positive and negative) rates, which serve to analyze a time interval preserved in the record between each pair of chosen stratigraphic surfaces. This idea is fully compatible with the depositional base-level concept, as defined by Jervey (1988) and presented in the Barrell diagram (Fig. 2). Furthermore, as time is incorporated into the concept, it avoids the common mistake of considering accommodation as a discrete variable, comparable to absolute measurements of bathymetry.

The distribution and the dynamics of relative accommodation rates in a sedimentary basin, during its evolution in geological time, are influenced mainly by allogenic processes (e.g., Shanley and McCabe 1994, Reading and Levell 1996, Coe et al.2003, Fig. 7). The allogenic influence on accommodation establishes limits to the autogenic process of generating and preserving sequences (Fig. 8). This understanding is particularly crucial for stratigraphic correlations since, in most cases, the effect of allogenic processes can be identified over large areas within a basin or even in different ones (e.g., Pittet and Strasser 1998).

In general, the environments distributed over different sectors of a sedimentary basin can be subdivided into marine (MAZ) and continental (CAZ) accommodation zones (Fig. 7). In MAZ, which extends from the open ocean to transitional environments close to the shoreline, variations in accommodation are primarily controlled by basin tectonics and, mainly, by eustasy, whose integration results in the relative sea level (e.g., Hunt and Tucker 1992). It is essential to consider that eustasy is not an independent factor, and a large part of its dynamics corresponds to a climatic effect (see items "Conceptual Foundation" and "Allogenic SequenceGenerating Mechanisms"). For this reason, in Figure 7, the "pure" climate process loses influence as the eustatic process becomes prevailing. In CAZ, the same reasoning for sea level can be adapted in lakes settings. The dynamics of accommodation in lake systems are due to tectonic and climatic variations (e.g., Bohacs et al. 2000). The region between the uplifted areas and the sea or lake level is connected mainly by fluvial systems. Variations in accommodation in this region are associated with the dynamics of the equilibrium profile (e.g., Miall 1996, Posamentier and Allen 1999), and all allogenic processes (tectonics of source area, basin subsidence, climate, and eustasy), intrinsically combined with autogenic processes, can promote changes in sedimentation patterns (Catuneanu 2006).

There is no way to define the end of the MAZ and the beginning of the CAZ since it is a gradual and variable limit in geological time. Throughout this transition, eustasy exerts

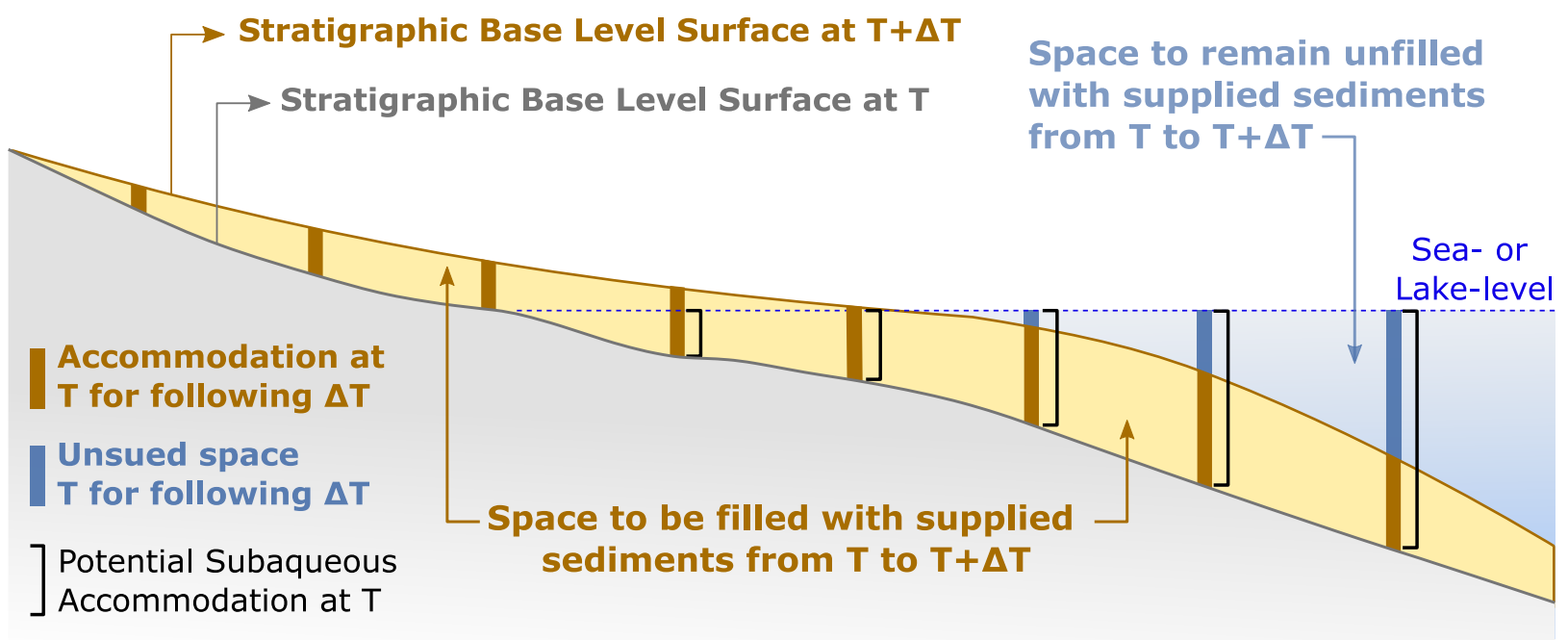

Source: modified from Muto and Steel (2000).

Figure 6. Accommodation can be considered as the resulting amount of space filled by sediments in each $\Delta \mathrm{T}$. The potential accommodation, that is, the maximum possible magnitude of accommodation that considers bathymetry, should be evaluated only within a specific time ( $\mathrm{T}$ ) and does not apply to subaerial environments. 


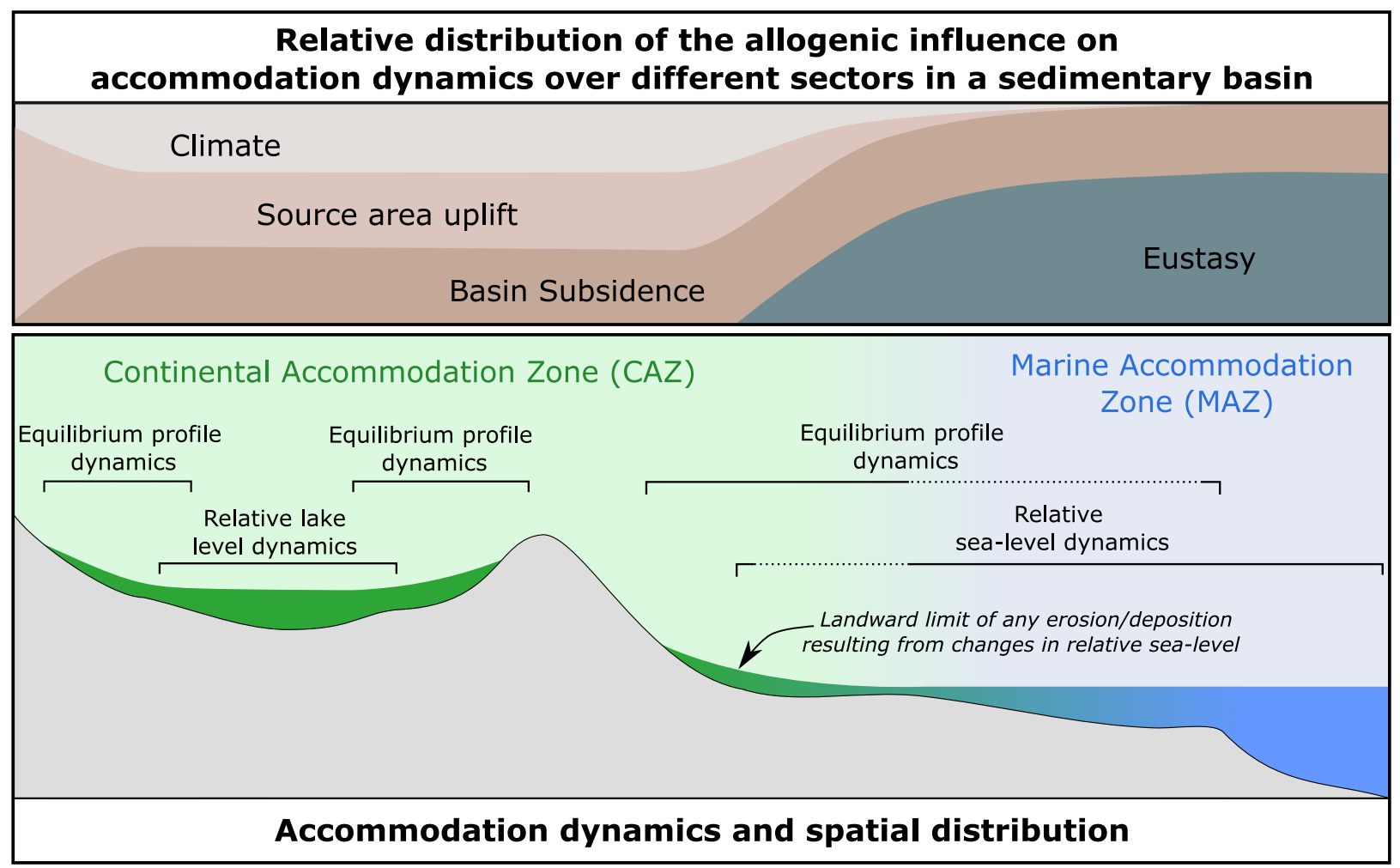

Source: based on Shanley and McCabe (1994) and Coe et al. (2003).

Figure 7. Dynamics and spatial distribution of accommodation over the different sedimentary environments - marine (Marine Accommodation Zone - MAZ) and continental (Continental Accommodation Zone - CAZ). The dynamic of accommodation is strongly controlled by allogenic factors (climate, eustasy, subsidence of the basin, and elevation of the source area), but their relative influence varies along the basin. The main difference is in eustasy, which gradually loses its influence towards the Continental Accommodation Zone, where other controlling factors prevail.

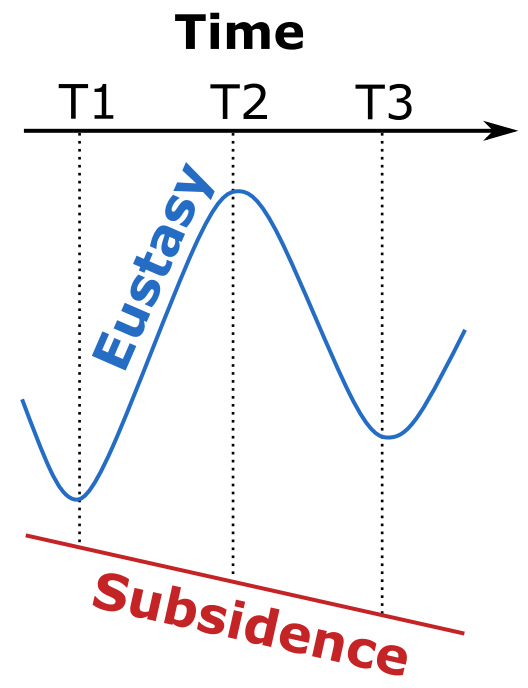

T2 - Intermediate equilibrium profile (Allogenic limit for generation)

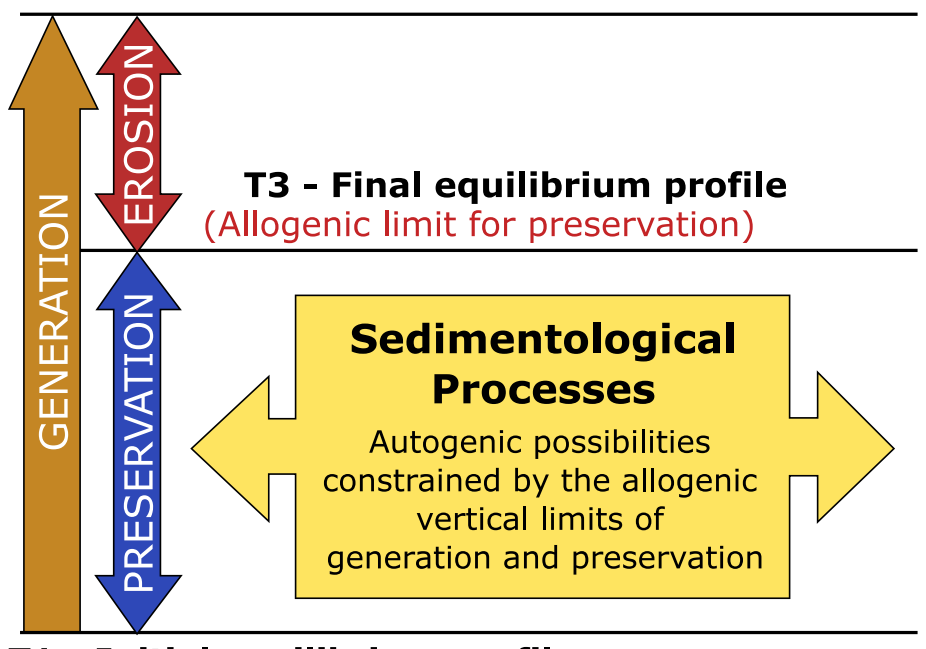

T1 - Initial equilibrium profile

Figure 8. Interaction and contribution of allogenic and autogenic factors in the development of sequences of any scale. The generation (in $\mathrm{T} 2$ ) and preservation (in T3) resulting from eustasy and tectonic phenomena will always stratigraphically limit the preserved product of the continuous deposition governed by autogenic factors.

control - primary or secondary — in the deposition and preservation of marine and continental strata. The sequence stratigraphy literature has dedicated itself so much to analyze the sedimentary record over this transition that its nomenclature is primarily associated with shoreline trajectories (e.g.,
Embry 1993). However, it is crucial to consider that what is observed in the sedimentary record are the preserved progradational and retrogradational stacking patterns and stratigraphic surfaces used to interpret regression and transgression trends of the shoreline. For the characterization of stacking patterns, 
variations in accommodation rates and sedimentary supply are considered together (e.g., Catuneanu 2006).

\section{Stacking patterns: the accommodation/ sediment supply (A/S) ratio concept}

The stacking patterns correspond to the record of organized sedimentary successions, where sedimentation trends are identified. Its concept underlies basic principles when defining stratigraphic units and sequence stratigraphy surfaces, regardless of scale (Catuneanu et al. 2011).

The criteria for defining stacking patterns range from facies relationships and layer geometry to reflector termination patterns seen in seismic data. They can be descriptive, regarding observations of the relationships between texture (coarsening and fining upward) and thickness (thickening and thinning upward) of sedimentary facies. However, they can also be interpretative, based on proximality and distality relationship (shallowing-upward and deepening-upward).

Stacking patterns can be understood as the record of paleogeographic evolution during fluctuations in accommodation (A) and sediment supply (S) rates (e.g., Shanley and McCabe 1994; Fig. 9). When accommodation rates are positive $(\mathrm{A}>0)$, stacking patterns can be aggradation $(\mathrm{A} / \mathrm{S}$ ratio $=1)$, progradation $(0<\mathrm{A} / \mathrm{S}<1)$ or retrogradation $(\mathrm{A} / \mathrm{S}>1)$. From these stacking patterns, the displacement of depositional systems and the shoreline trajectory are interpreted. Thus, retrogradation records shoreline transgression (i.e., the landward migration of depositional systems), and progradation records shoreline regression (i.e., the basinward migration of depositional systems). Aggradational stacking patterns correspond to a hypothetical situation in which the shoreline remains stationary. However, this term is most often used generically, describing vertical layer recurrence in any situation where $\mathrm{A}>0$ (e.g., fluvial topset; Catuneanu 2006).

The A/S ratio concept can also be satisfactorily used to define stacking patterns in fluvial systems, regardless of sea or lake level influence (e.g., Martinius et al. 2014). In general, the degree of amalgamation of channels in proportion to the overbank facies and the development of paleosols are used to characterize patterns of low-accommodation (or high-amalgamation; $0<\mathrm{A} / \mathrm{S}<1$ ) and high-accommodation (or low-amalgamation; A/S > 1) (e.g., Wright and Marriott 1993, Shanley and McCabe 1994, Currie 1997, Martinius et al. 2014).

Regressions also occur when accommodation rates are negative $(\mathrm{A}<0)$ during the base-level fall (i.e., forced regression). At these times, large areas are eroded at the margin of the basin with concomitant deposition in relatively deep waters. The shoreline trajectory during $\mathrm{A}<0$ is called forced regression, in contrast to the normal regression interpreted when $\mathrm{A}>0$.

Correlations based on stacking patterns imply that depositional controls acted synchronously in many portions of the basin. However, it is necessary to consider that, in many cases, different stacking patterns can develop simultaneously due to different $\mathrm{A} / \mathrm{S}$ rates along the depositional area. This condition is more critical at high-frequency analysis in tectonically active contexts, such as in foreland (reciprocal stratigraphy sense Cantueanu et al. 1999) and rift basins (e.g., Howell and Flint 1996, Kuchle and Scherer 2010, Holz et al. 2017; Fig. 10). For this reason, understanding the geological processes that control variations in accommodation, sedimentary supply, and the preservation of stacking patterns is essential to describe and interpret the stratigraphic record. This comprehension provides robustness in the development of chronostratigraphic conceptual models in the most diverse depositional contexts, including, for example, glacial (e.g., Powell and Cooper 2002), eolian (e.g., Bállico et al. 2017), and deep water (e.g., De Gasperi and Catuneanu 2014) environments.

\section{ALLOGENIC SEQUENCE-GENERATING MECHANISMS}

\section{Eustasy}

Eustasy is understood as a process of variation of the global sea level, measured to a fixed datum, commonly the Earth center (e.g., Conrad 2013). During the 1970s and 1980s, seismic stratigraphy emphasized the importance of eustasy as the dominant control in stratigraphic architecture (Miall 2010). Climatic controls on eustasy (glacio-eustasy) were mainly associated with the generation of sequences (e.g., Frazier 1974). However, the diastrophic (tectonic) impact is related to eustatic fluctuation since its conception (Miall 2010). The most accepted understanding is that eustasy is the combination of tectonic and climatic processes that cause changes in the ocean water volume and the average container volume (capacity) of ocean basins (e.g., Sames et al. 2016, Sames et al. 2020, Fig. 11).

The variations in the available volume of ocean basins correspond to "long-term" processes (greater than $1 \mathrm{Ma}$ ), related mainly to the internal dynamics of the Earth that promote changes in the geometries and dimensions of the basins, as well as in their respective magmatic or sedimentary filling (e.g., Sames et al. 2016, Ray et al. 2019). The controls of change in the ocean water volume include the processes of thermal expansion (thermo-eustasy) and the storage of water on the continents, either in the form of ice (glacio-eustasy) or underground and surface reservoirs (aquifer-eustasy) (e.g., Sames et al.2020). Such processes are "short-term" (up to $1-3$ $\mathrm{Ma}$ ), driven mainly by astronomical/climatic cyclicity (e.g., Pittet and Strasser 1998). In addition, there is also the possibility of exchanging water between the ocean and the Earth's mantle, which involves higher time scales (e.g., Ni et al. 2017, Nakagawa et al. 2018).

\section{Tectonics}

Although eustatic phenomena have been particularly vital to broadening the discussion on global chronostratigraphic correlations, their role, as proposed in the early days of seismic stratigraphy (e.g., Payton 1977), proved to be insufficient to describe all sea-level variations observed in different contexts or scales (Miall 2016). This conclusion was crucial for developing the "relative sea level" concept (e.g., Wilgus et al. 1988). Local tectonics, coupled with eustatic changes, cause significant sea-level variations, operating changes in accommodation 


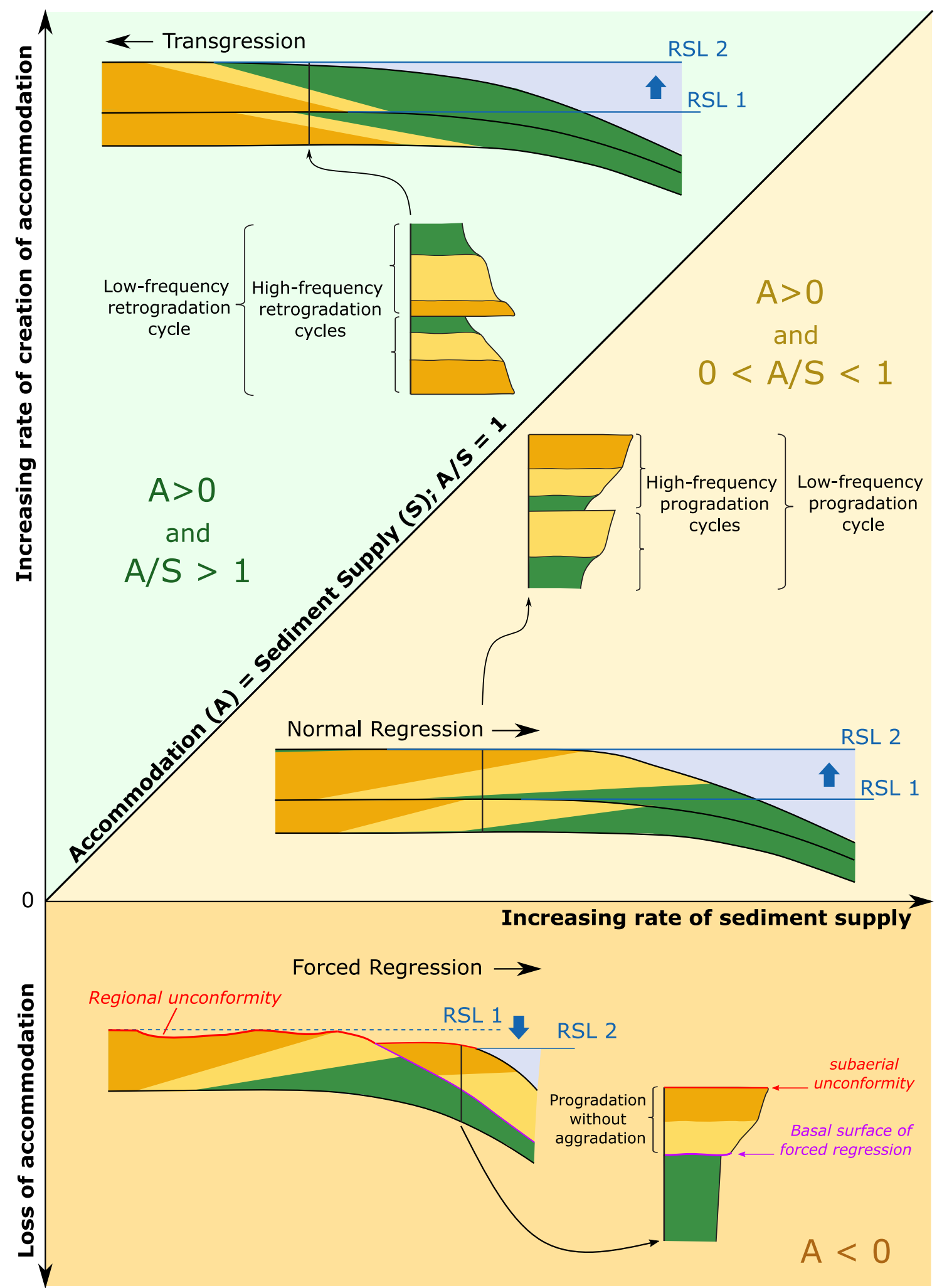

Source: modified from Shanley and McCabe (1994).

Figure 9. Schematic graph illustrating stacking patterns resulting from the balance between variations in accommodation (A, in this case, controlled by relative sea level — RSL) and sedimentary supply (S) rates (modified from Shanley and McCabe 1994). When accommodation rates are positive $(\mathrm{A}>0)$, stacking patterns (progradation and retrogradation) and shoreline trajectories (normal regression and transgression, respectively) depend on the relationship with sedimentary supply rates $(\mathrm{A} / \mathrm{S})$. When the accommodation rate is negative $(\mathrm{A}<0)$, erosion occurs landwards, and sedimentation advances to the depocenter, developing forced regression.

rates with various amplitudes and frequencies (e.g., Matenco and Haq 2020).

As mentioned, tectonics contributes globally to changes in the container volume (capacity) of the ocean basins. The tectono-eustasy (Fairbridge 1961) occurs over very long-time scales, producing deformation of ocean basins during the opening and closing of the oceans during the Supercontinent Cycles (or Wilson Cycles). However, beyond the changes in the volume of the ocean basin, the tectonic dynamics responsible for the "Supercontinent Cycles" during the Phanerozoic 


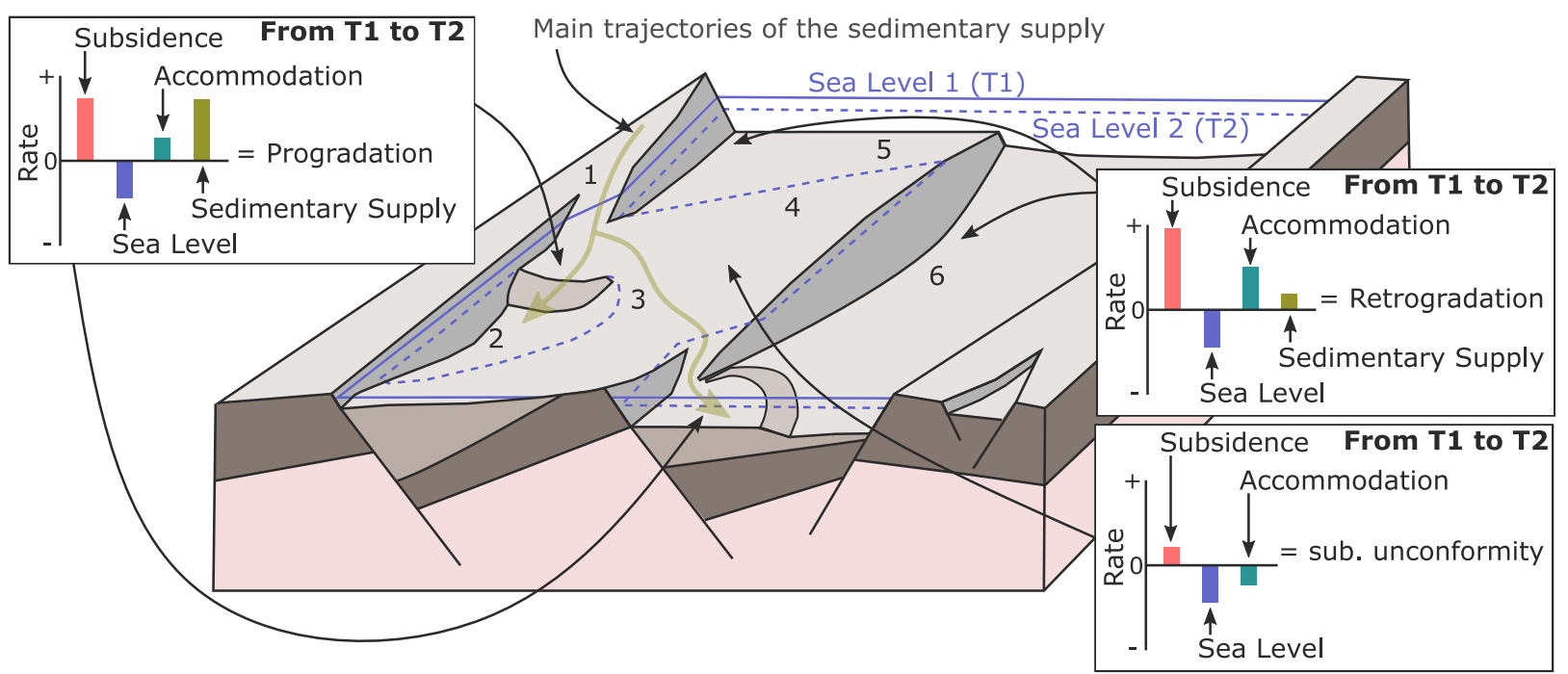

1. Transfer zone at fault offset. Sediment input point. / 2. Hangingwall trough. / 3. Significant change in shoreline orientation following sea level fall. / 4. Localized ramp geometry oblique to general depositional dip direction./

5. Localized shelf/slope break at fault scarp. / 6. Maximum subsidence in center of fault ellipse.

Source: modified from Howell and Flint (1996).

Figure 10. Schematic diagram showing different stacking patterns and surfaces developed simultaneously along a rift basin.

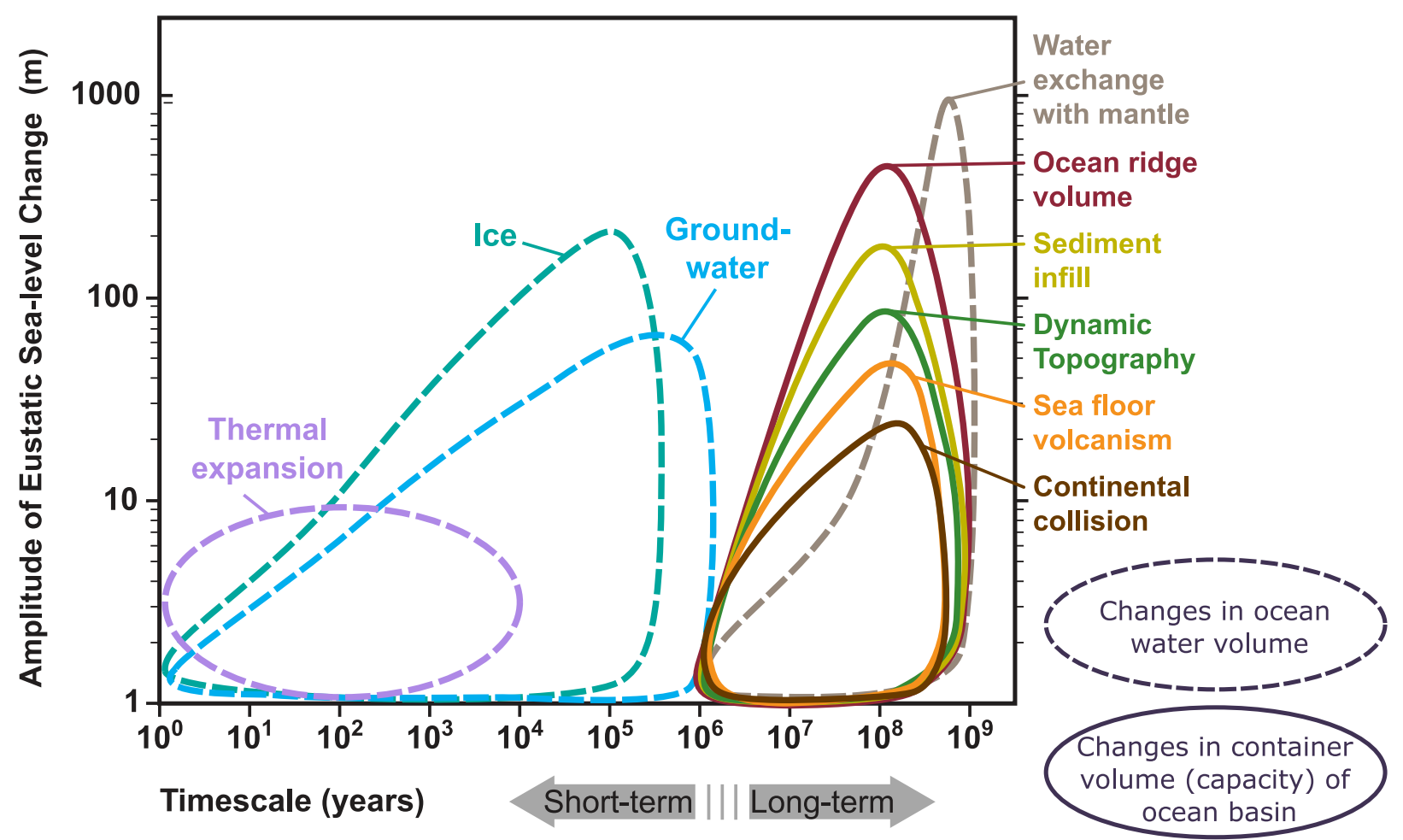

Source: modified from Sames et al. (2016) and Sames et al. (2020).

Figure 11. Log-scale diagram of the timing and amplitudes of the main mechanisms that control eustasy (modified from Sames et al. 2016 and Sames et al. 2020). The values represented must be considered as average dimensions.

also influenced the Earth's climate, causing alternation between the Icehouse and Greenhouse stages (Fischer 1981, Kidder and Worsley 2010; Fig. 12).

During Icehouse, ice retains part of the ocean water. Conversely, during Greenhouse, high temperature inhibits ice formation on the continents. The association of these long-term climatic stages with tectonic dynamics and eustatic variations results in long-term oscillations in the eustatic level (i.e., high during Greenhouse and low during Icehouse). It is necessary to consider that, despite wide variations in eustasy, changes in sedimentary environments throughout this cycle will only be preserved if local subsidence rates allow the balance of accommodation to be positive (e.g., Strasser et al. 1999). Besides that, changes in accommodation rates due to tectonic activity can be more significant than any other forcing factor at any spatial and temporal scale (Matenco and Haq 2020; Fig. 13). 


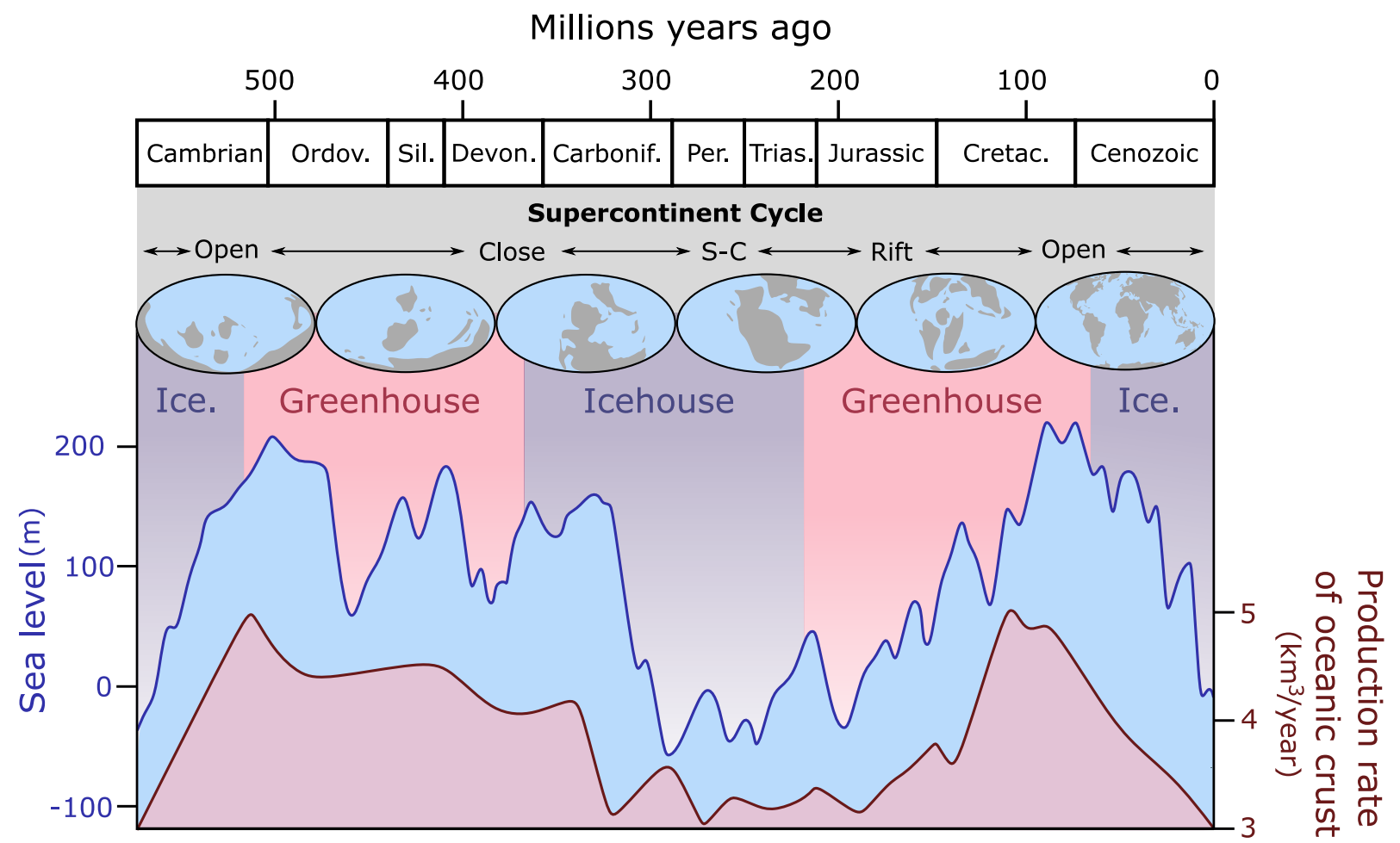

Source: based on Worsley et al. (1984), Takashima et al. (2006) and Nance et al. (2014).

Figure 12. Supercontinent $(\mathrm{S}-\mathrm{C})$ cycles during the Phanerozoic, including the alternation between Greenhouse and Icehouse stages, sealevel changes, and oceanic crust production rates.

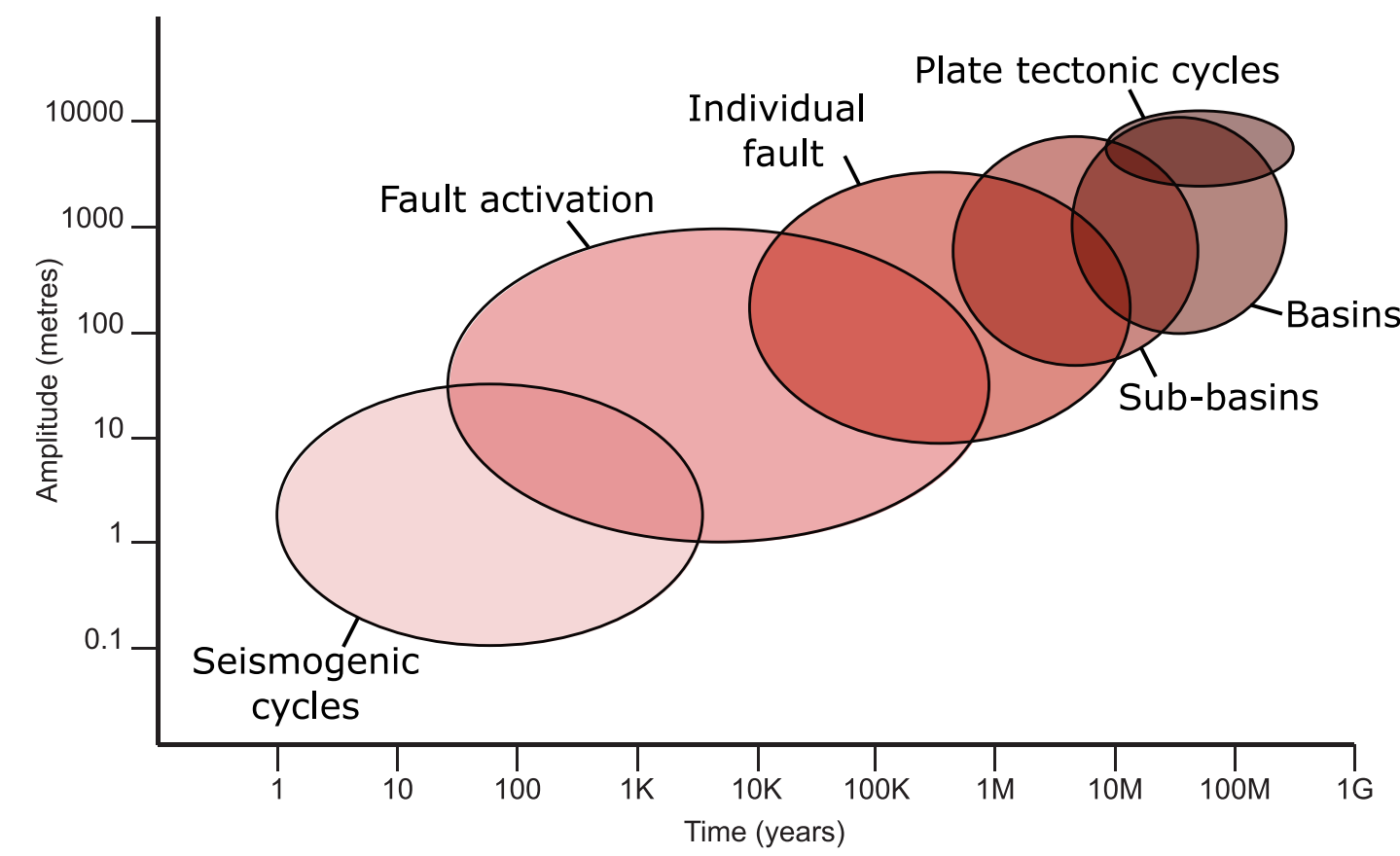

Source: modified from Matenco and Haq (2020).

Figure 13. Log-scale diagram of the timing and amplitudes of the main tectonic mechanisms that promote accommodation changes, ranging from plate tectonic cycles to basins, sub-basins, individual faults, fault activation moments, and seismogenic cycles.

It is noteworthy that many processes that promote the development of deformations and shifts in topography, engendering changes in accommodation rates that are not directly related to geotectonics, such as halokinesis (e.g., Rojo et al. 2020), sedimentary compaction (e.g., Khani and Back 2015), and glacio-isostatic adjustment (e.g., Dietrich et al. 2018).

\section{Climate}

As previously mentioned, planetary climate changes present a natural cyclic and regular dynamics, and many processes have the potential to leave their stratigraphic record preserved. Such processes have a wide range of known time frequencies, from daily scales to recurrences over millions of years. 
In addition to the global changes related to tectonic dynamics (e.g., Greenhouse and Icehouse; Fig. 12), astronomical cycles have been referred to in the literature as the main responsible for the planetary climate changes observed in the geological record (e.g., Strasser et al. 2007).

Even if not perfectly conservative, astronomical cycles are the most regular oscillation known in nature. For this reason, they are used as a geochronological reference in cyclostratigraphic research (see item "High-resolution Sequence Stratigraphy"). Astronomical cycles are multiple and periodic events (simple or compound) that range from Earth's rotation, recorded in tidal deposits (tidal bundles), to the oscillation and revolution cycles of the Solar System in the galaxy, which also impress a recognizable sign in the geological record (House 1995, Hinnov 2013, Oliveira et al. 2017; Fig. 14). Most investigations in cyclostratigraphy attribute

\begin{tabular}{|c|c|c|c|c|}
\hline \multicolumn{3}{|r|}{ Cycle } & \multirow{2}{*}{$\frac{\text { Time }}{1-1 \mathrm{~d} .}$} & \multirow{2}{*}{$\frac{\text { Mechanism / Cause }}{\text { Earth's rotation }}$} \\
\hline \multirow{23}{*}{ 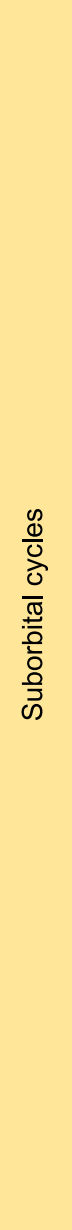 } & & Daily cycle & & \\
\hline & & Intra-season cycle & $180 \mathrm{~d}$. & Inclination of the Earth axis \\
\hline & & Annual cycle & $365 \mathrm{~d}$. & Earth's translation \\
\hline & El Niñc & o - Southern Oscillation (ENSO) & 2 to $7 \mathrm{y}$. & Lunar/planetary influence \\
\hline & & Schwabe cycle & $11 \mathrm{y}$. & Influence of planets (Jupiter and Saturn) \\
\hline & & Saros cycle & $18.1 \mathrm{y}$. & Lunar orbital parameter \\
\hline & & Lunar Nodal Cycle (LNC) & $18.6 \mathrm{y}$. & Lunar orbital parameter \\
\hline & & Hale cycle & $22 \mathrm{y}$. & Influence of planets (Jupiter and Saturn) \\
\hline & & Brückner cycle & $35 \mathrm{y}$. & Lunar/planetary influence \\
\hline & Interd & ecadal Pacific oscillation (IPO) & 15 to $30 \mathrm{y}$. & Lunar/planetary influence \\
\hline & Nor & th Atlantic Oscillation (NAO) & 25 to $35 \mathrm{y}$. & Lunar/planetary influence \\
\hline & Paci & fic Decadal Oscillation (PDO) & 50 to $70 \mathrm{y}$. & Lunar/planetary influence \\
\hline & Atlantic & Multidecadal Oscillation (AMO) & 50 to $90 \mathrm{y}$. & Lunar/planetary influence \\
\hline & & Lower Gleissberg cycle & $88 \mathrm{y}$ & Influence of planets (Jupiter and Saturn) \\
\hline & & Upper Gleissberg cycle & $120 \mathrm{y}$. & Influence of planets (Jupiter and Saturn) \\
\hline & & Jose cycle & 179 y. & Influence of planets (Jupiter and Saturn) \\
\hline & Sue & ss Cycle (or De Vries Cycle) & 208 y. & Influence of planets (Jupiter and Saturn) \\
\hline & & 500 year cycle & $500 \mathrm{y}$. & Influence of planets (Jupiter and Saturn) \\
\hline & & Eddy cycle & $1,000 \mathrm{y}$ & Influence of planets (Jupiter and Saturn) \\
\hline & & insgaard-Oeschger events & $1,500 \mathrm{y}$ & Solar influence \\
\hline & & Bond events & $1,500 \mathrm{y}$ & Solar influence \\
\hline & & Hallstatt cycle & $2,300 \mathrm{y}$. & Influence of planets (Jupiter and Saturn) \\
\hline & & Heinrich events & 10 my. & Solar influence \\
\hline \multirow{6}{*}{ 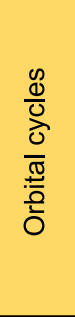 } & Milankovitch & Interglacial & 10 my. & Combination of orbital parameters \\
\hline & cycle & Glacial & 100 my. & Combination of orbital parameters \\
\hline & & Precession & 20 my. & Orbital Parameter \\
\hline & & Obliquity & 40 my. & Orbital Parameter \\
\hline & & Short eccentricity & 100 my. & Orbital Parameter \\
\hline & & Long eccentricity & 400 my. & Orbital parameter \\
\hline \multirow{2}{*}{ 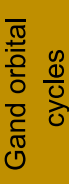 } & & Very long obliquity & $1.2 \mathrm{My}$ & $\begin{array}{c}\text { Gravitational interactions between the Earth } \\
\text { and Mars }\end{array}$ \\
\hline & & Very long eccentricity & 2.4 My. & $\begin{array}{c}\text { Gravitational interactions between the Earth } \\
\text { and Mars }\end{array}$ \\
\hline 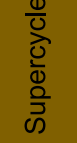 & Major impe & $\begin{array}{l}\text { act event (asteroids / meteorites) or } \\
\text { Galactic cycle }\end{array}$ & 30 My. & $\begin{array}{l}\text { Vertical oscillation of the Solar System } \\
\text { perpendicular to the mid-plane of the Galaxy }\end{array}$ \\
\hline
\end{tabular}

Legend: $d=$ day(s); $y=$ year(s); my = thousands of years; My = Millions of years.

Source: modified from Oliveira et al. (2017).

Figure 14. Synthesis of climatic cycles, their timing, and the related astronomical mechanisms. 
to the Milankovitch cycles (Fig. 15) the main recurrences observed in the stratigraphic record in outcrop and core scale (e.g., Wu et al. 2013; Fig. 16). However, higher-resolution studies have shown that orbital signals are commonly superimposed by higher frequency cycles (sub-orbital cycles) with the recurrence spectrum from centennial to annual scale (e.g., Li et al. 2019; Fig. 17).

The success of the theory presented by Milankovitch (1941) derives from his precise calculations that demonstrated how the orbitally driven variability in the solar

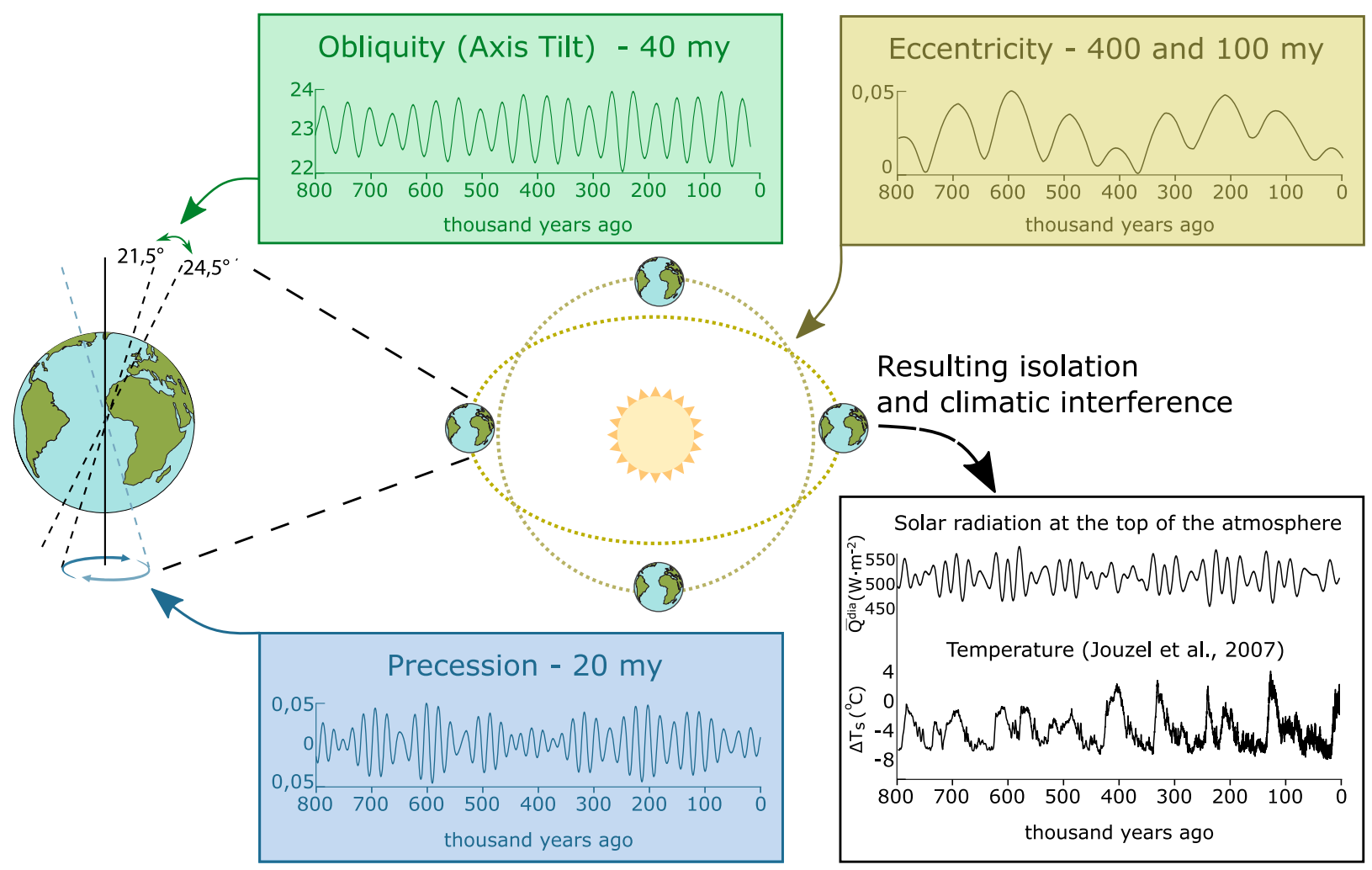

Source: modified from Oliveira et al. (2017) and Jouzel et al. (2007).

Figure 15. Orbital parameters (Milankovitch cycles) and the result of the solar radiation at the top of the atmosphere in the subsequent control of global temperature in the last 800 thousand years.

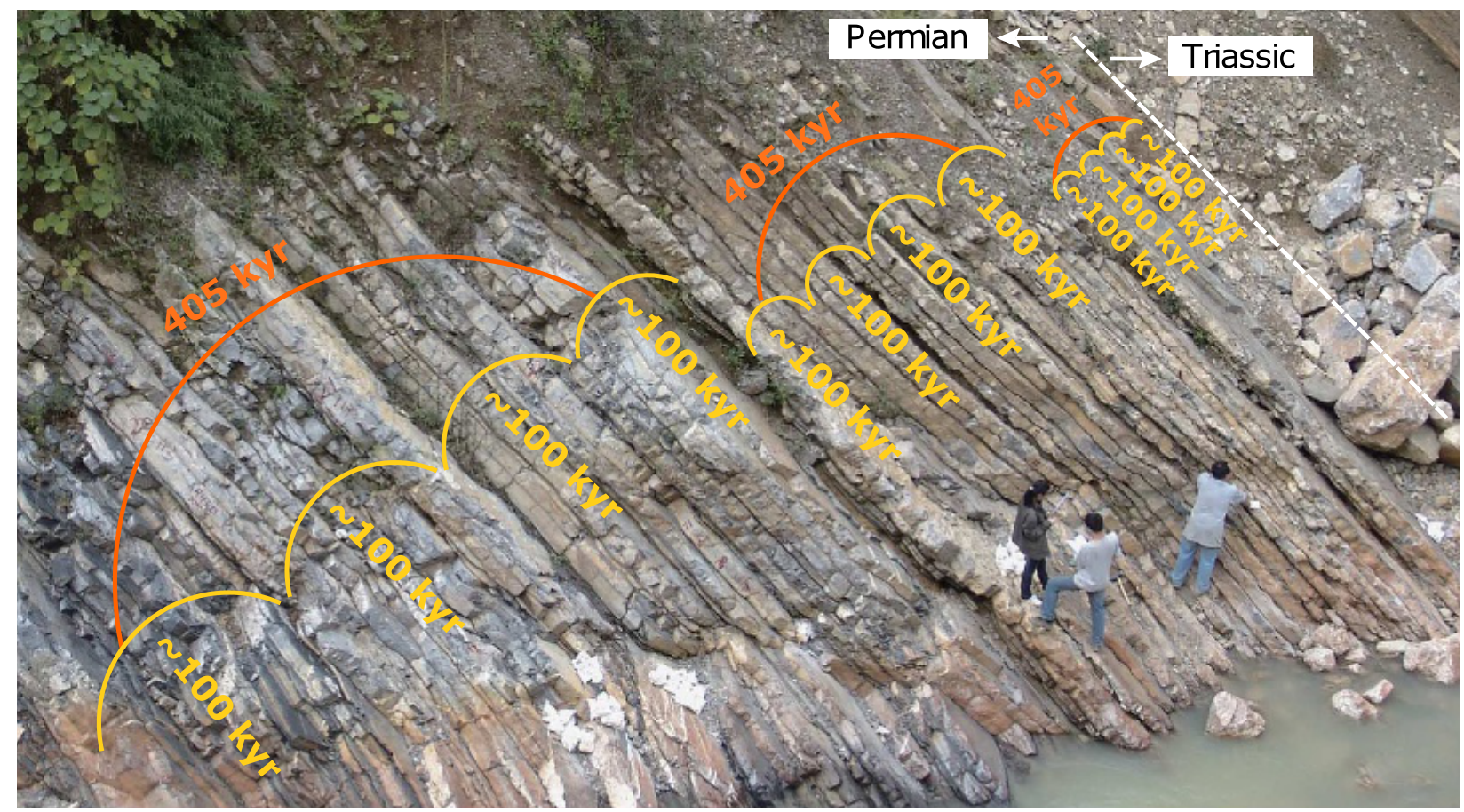

Source: modified from Wu et al. (2013).

Figure 16. Visual identification of Milankovitch cycles in an outcrop of Permian marine carbonates from the Dalong Formation, China (modified from Wu et al. 2013). Note the groups of layers identified as a product of precession forming cycles of 100 kyr (short eccentricity) regrouped in cycles of $405 \mathrm{kyr}$ (long eccentricity). 


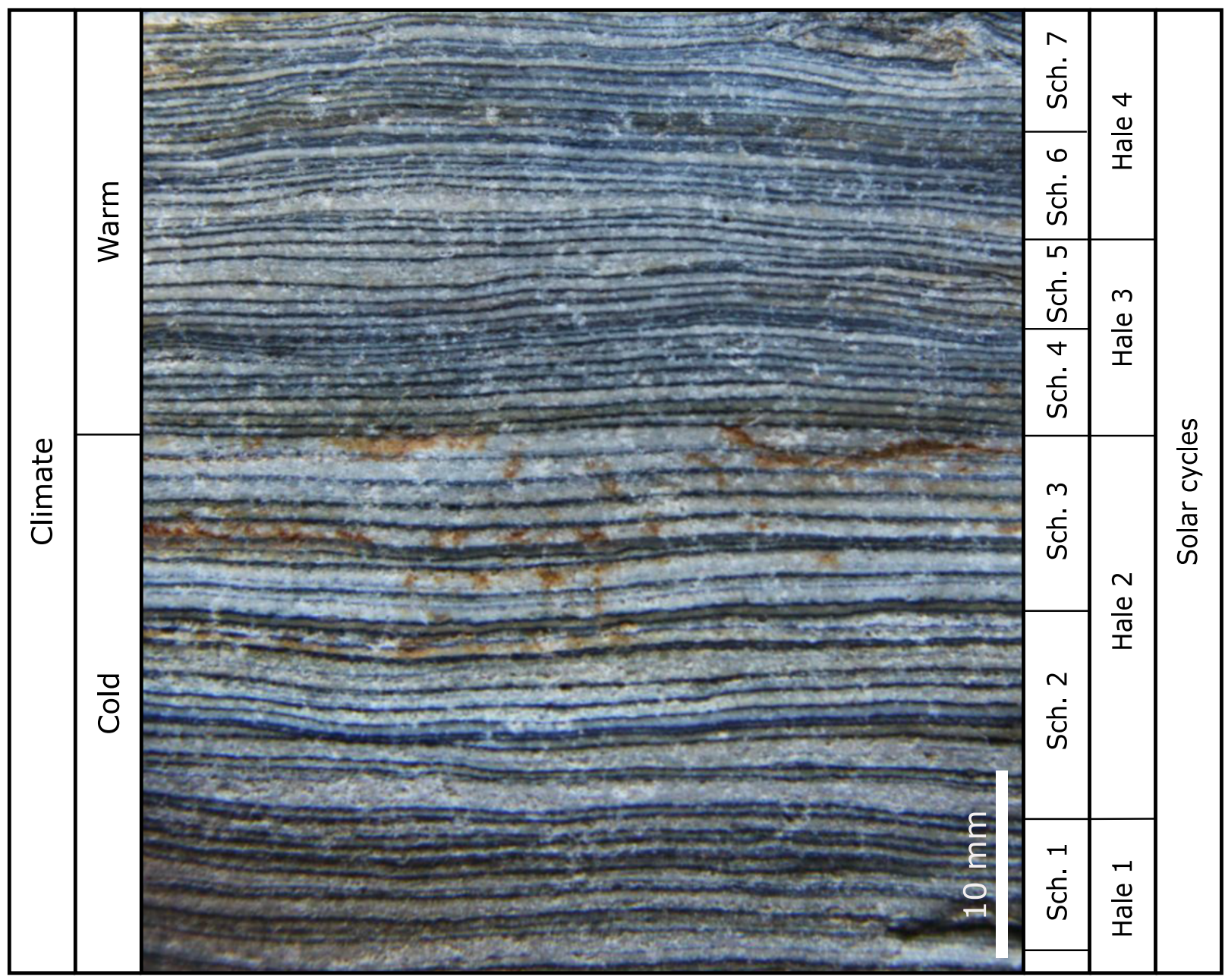

Source: from Li et al. (2018).

Figure 17. Schwabe (Sch. 1 to 7) and Hale (1 to 4) cycles (see Fig. 14 for references) identified in shallow marine deposit with microbial influence of the Wuqiangxi Formation, Neoproterozoic (810-715 Ma) in South China.

radiation received by the Earth over time determines the glacial/interglacial cycles during Icehouse stages. Currently, the orbital parameters satisfactorily explain the main climatic cycles in geological time, being a reference to determine, for example, the short-term eustatic changes in both the Icehouse and Greenhouse stages (e.g., Sames et al. 2020; Fig. 11).

Besides eustatic changes, the constant variations in insolation result in climatic impacts that, ultimately, exert an influence of different magnitudes not only on accommodation rates in continental environments but also on the sedimentary supply rates of organic and inorganic sediments (Li et al. 2019). Furthermore, as climate and tectonics are coupled systems, feedback effects can occur at different scales. For example, the intensity of erosion promoted by the climate on a tectonically deformed crust can stimulate faults motion due to reducing lithostatic load (Allen 2008). Therefore, a systematic analysis is always required to understand the boundary conditions of sedimentation and preservation in the stratigraphic record, and a multi-frequency sequence stratigraphic analysis can be a satisfactory way to achieve a solution.

\section{SEQUENCE HIERARCHY}

\section{Accordion effect of resolution on stratigraphic analysis}

Characterizing and understanding the multi-scale cyclical behavior of the sedimentary record has been one of the most critical aspects of stratigraphic analysis (Schwarzacher 1993, 2000). In the context of sequence stratigraphy, the stratigraphic cyclicity observed at different scales can be described as sequences from different hierarchical levels, in which the stacking pattern of a higher order is composed of an organized amalgamation of lower rankings sequences (Catuneanu 2006, 2019a, Magalhães et al. 2020; Fig. 18).

The most accepted hierarchical sequence classification starts with a basin-fill reference (Catuneanu 2006). Thus, a first-order sequence is defined as the complete filling of a sedimentary basin developed within a specific tectonic configuration. Therefore, a first-order sequence can be subdivided into second and subsequently lower orders. As a corollary, the magnitude of correlation should decrease, and, inversely, the recurrence of stratigraphic surfaces should increase toward the lower hierarchical level. 


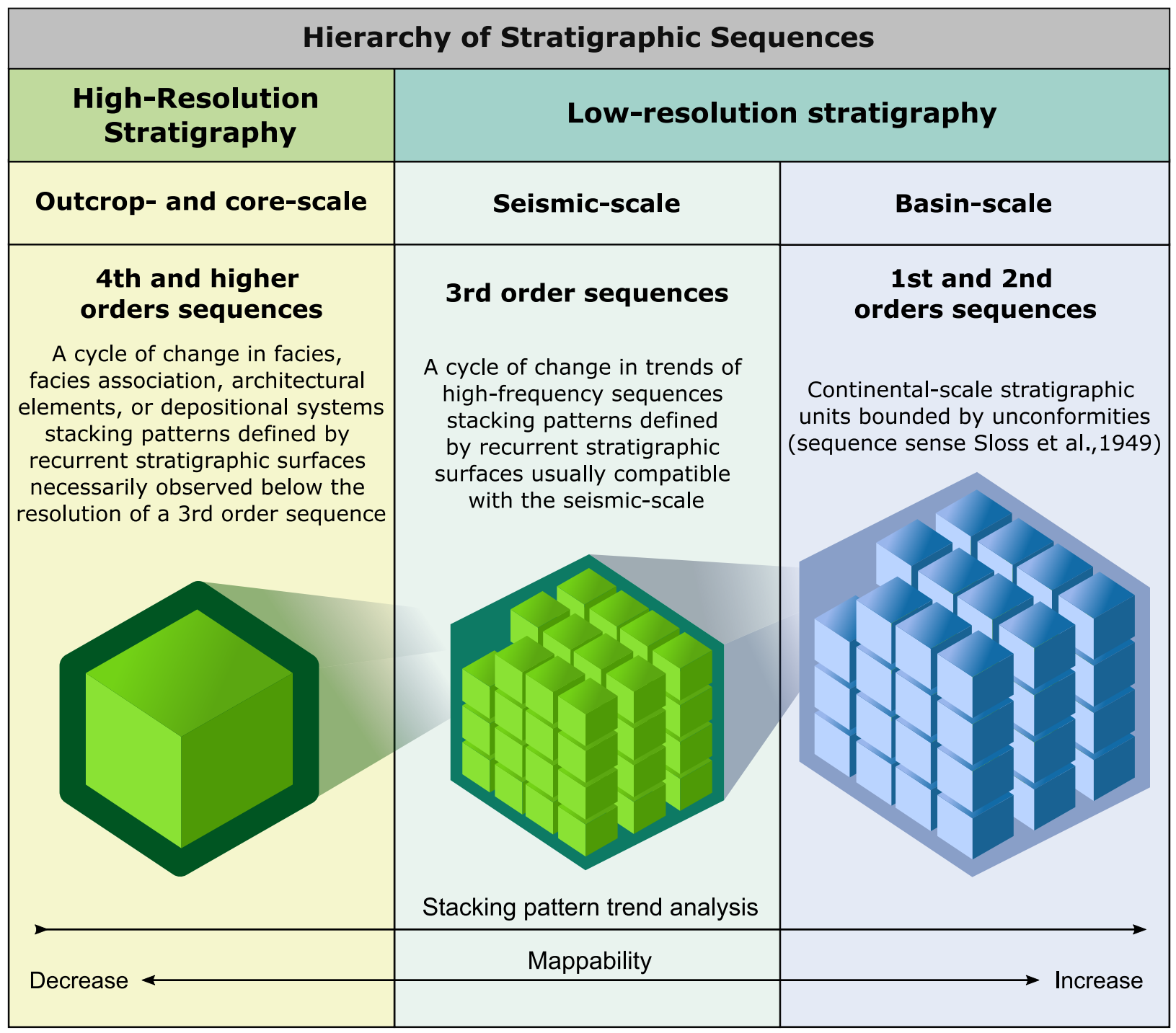

Source: modified from Magalhães et al. (2020).

Figure 18. Hierarchy of stratigraphic sequences based on cycles observed at different scales.

Each sequence hierarchy observed in a sedimentary succession can be understood as a product of accommodation variation in different magnitudes and durations (e.g., Neal and Abreu 2009). An analogy proposed here to understand the resolution in sequence analysis resulting from a variable spectrum of accommodation is named the "accordion effect". A gain of resolution in detecting the high-frequency signal of fluctuations in the $\mathrm{A} / \mathrm{S}$ ratio (short duration) occurs at times of high rates of long-term accommodation. In this sense, it is like the expansion of accordion's folds (Fig. 19.1). When the increase in long-term accommodation is not significant, there is a decrease in the high-frequency sequence resolution (Fig. 19.2). Jerolmack and Paola (2010) describe this phenomenon as "signal shredding", when there is the removal of evidence of short-term fluctuation in the $\mathrm{A} / \mathrm{S}$ ratio of the sedimentary record as a consequence of the energetic and dispersive action of the sedimentary processes, generating missing beats (e.g., Hardie et al. 1986, Steinhauff and Walker 1995, Strasser 2015). On the other hand, the lack of definition for high-frequency stratigraphic analysis can also happen when potential accommodation is high and sedimentation rates are very low, as is the case of condensed sections (Strasser 2015). Hence, as accommodation rates are continually changing, the visible "accordion effect" in the vertical scale of low-frequency analysis occurs from hiatus zones to condensation zones, and vice versa. In correlations, the resolution of the stratigraphic analysis varies according to the "potential accommodation" (sense Muto and Steel 2000; Fig. 7). At each correlatable interval, there will be a relative increase in the resolution of stratigraphic analysis (accordion effect) toward the down-dip of paleogeographic variations (Fig. 20).

In general, the long- and short-term relationship is arbitrary, and this sequence subordination analysis is valid for all observable scales. Thus, the possibilities for generating and preserving stacking patterns of any frequency are controlled by the vertical limits of accommodation and preservation of a higher hierarchical level, engendering the preservation of every high-frequency cycle.

An example of resolution for different sequence hierarchies (1st- to 4th-order) is observed in the Mesoproterozoic Tombador 


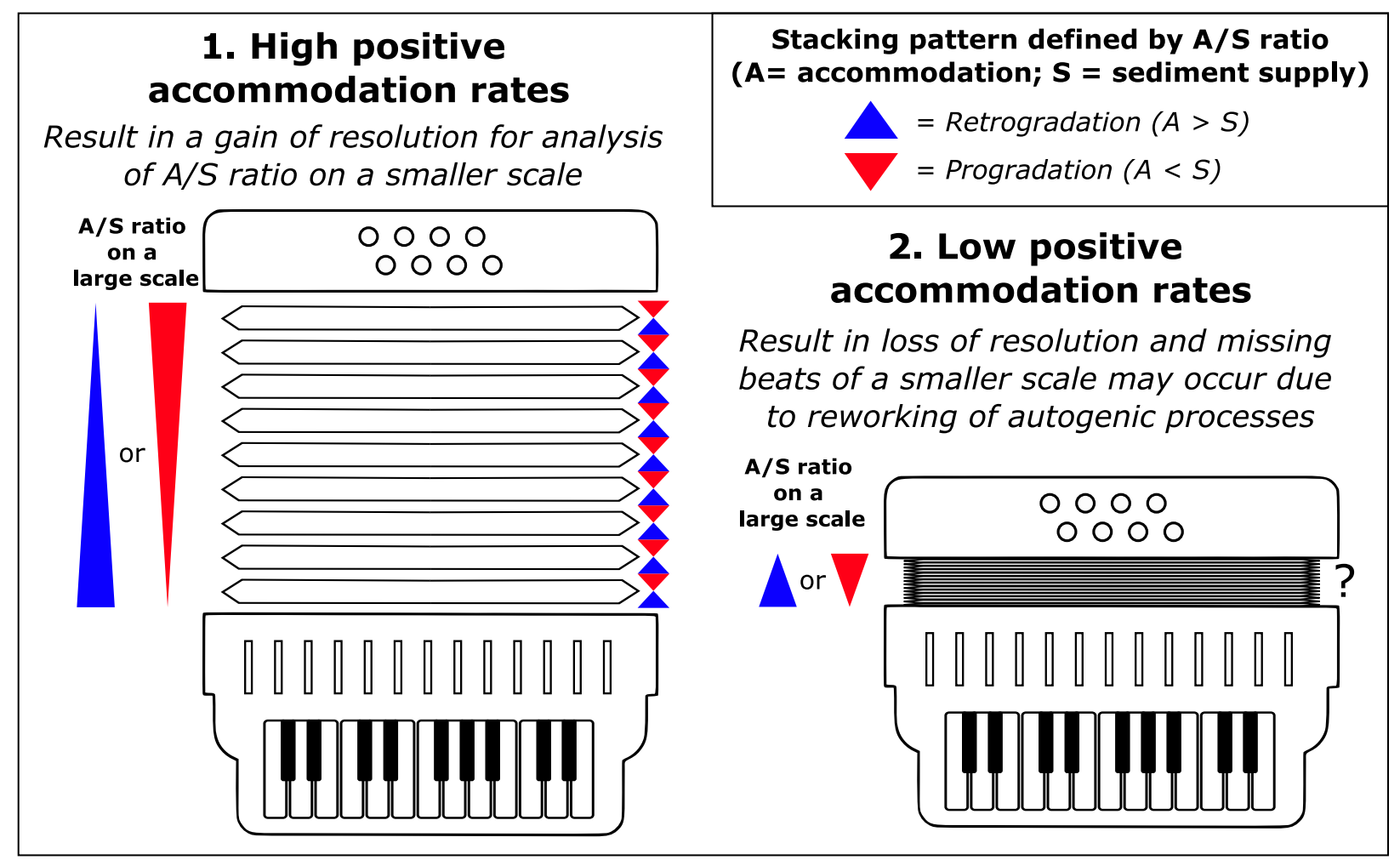

Figure 19. Accordion effect of resolution on stratigraphic analysis. Relative values of high (1) or low (2) rates in long-term (positive rate) accommodation define the possibilities of generation and preservation of the stacking pattern resulting from the high-frequency fluctuation in the $\mathrm{A} / \mathrm{S}$ ratio.

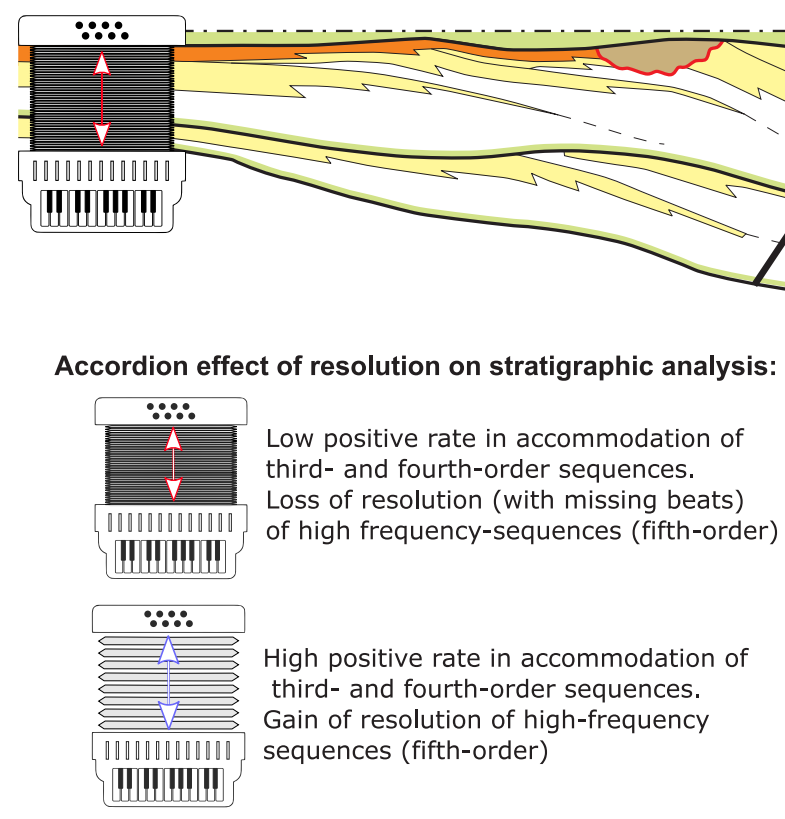

Source: modified from Bhattacharya (1993) and Catuneanu (2019b).

Figure 20. Sequences, systems tracts, and depositional systems observed at different scales (i.e., hierarchical levels), generated by the fluctuation in the $\mathrm{A} / \mathrm{S}$ ratio, in a stratigraphic architecture of a prograding system.

Formation, northeastern Brazil (Magalhães et al. 2016). At the Tombador Formation base, third-order sequences are characterized by alternating estuarine/marine and continental deposits (Fig. 21). The highest sequence resolution (4th-order) occurs in the estuarine intervals within the third-order transgressive systems tract (high accommodation rate), involving contrasting facies associations. However, the resolution for high-frequency sequences in the third-order continental intervals (lower accommodation rate) is poorer, which is pronounced by the aggradation of monotonous successions of fluvial sandstone deposits. 


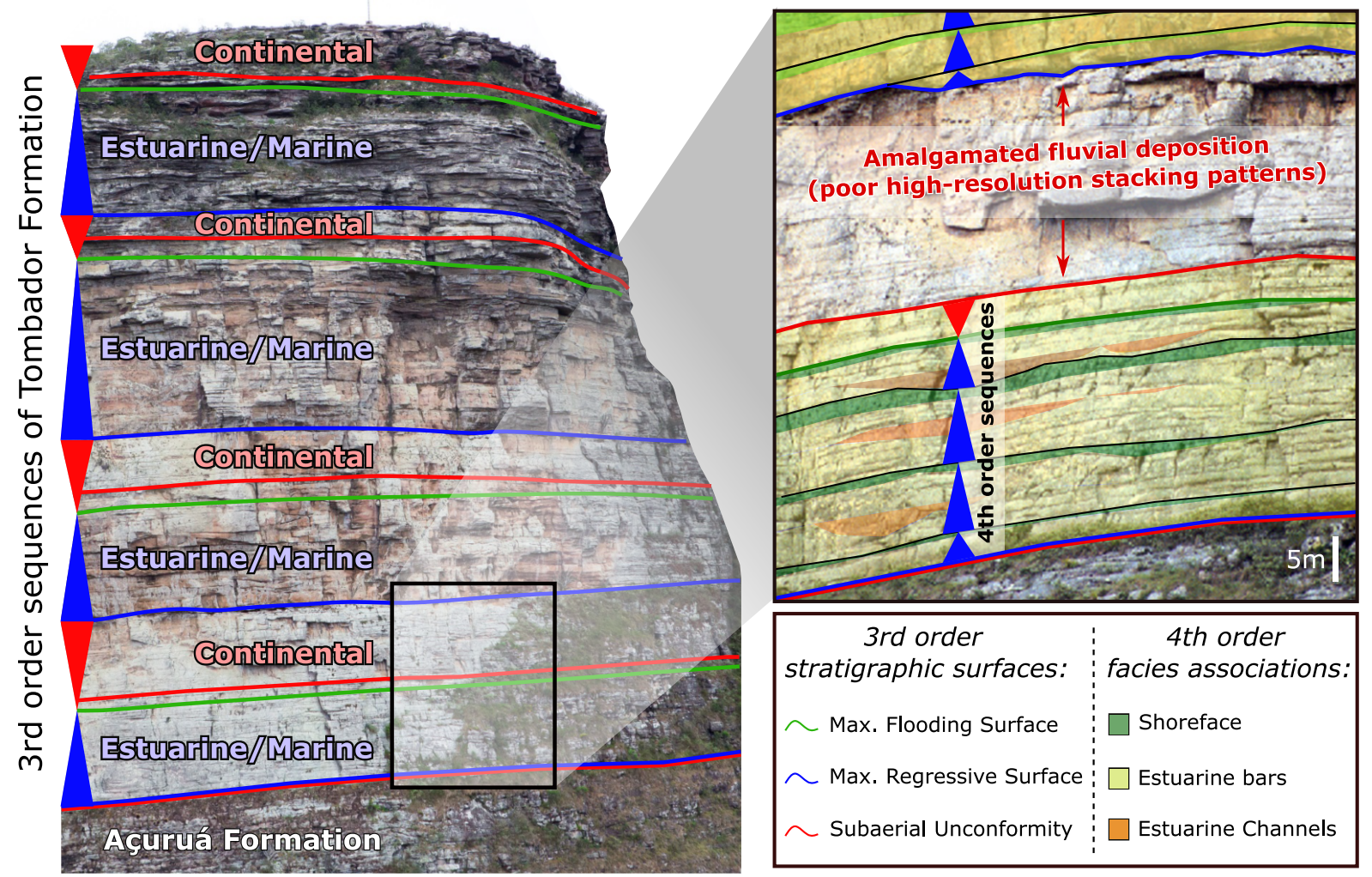

Figure 21. Stratigraphic framework of the third- and fourth-order sequences of the Tombador Formation (Mesoproterozoic, Brazil; Magalhães et al. 2016). The fourth-order sequences (highest resolution), characterized by the alternation of estuarine and shoreface facies associations, are well observed in the third-order transgressive intervals (high accommodation setting). In the low accommodation setting of the regressive continental intervals, high-resolution sequences are poorly identified.

It is interesting to note that the energetic and dispersive effect of sedimentary processes is, in general, more intense in allochthonous than in autochthonous sedimentation. For this reason, carbonate and evaporitic contexts tend to have higher resolution for the analysis of stacking patterns, as observed in the case of the lacustrine carbonate deposits of the Salta Basin (e.g., Bento Freire 2012, Bunevich 2016, Bunevich et al. 2017, Fig. 22).

\section{Criteria for identifying sequences in a hierarchical framework}

The premises here are: any displacement of facies in terms of proximity and laterality, intrinsic to their respective depositional systems, within correlatable intervals of equivalent stacking patterns, is controlled by the $\mathrm{A} / \mathrm{S}$ ratio; and different limits of accommodation constrain distinct preservation potential. In this sense, the cycles' anatomy, recurrence, vertical trends, and the mappability of stacking patterns and stratigraphic surfaces are the observable criteria for identifying sequences, at any scale and rank, within a hierarchical stratigraphic framework (Fig. 23).

The analysis of cycle anatomy is a primary and robust descriptive criterion for the proposal of a sequence. At any scale of observation, a sequence must have a typical internal Transgressive-Regressive pattern (T-R cycle) bounded by the maximum flooding surface (end of transgression) or by the maximum regressive surface (end of regression) (e.g., Embry
$1995,2009)$. The subdivision of sequences in facies or system tracts can be more complex (e.g., Van Wagoner et al. 1990) depending on the scale (seismic or outcrop) and context (e.g., basin morphology). However, as all types of sequences (Fig. 1) exhibit the T-R pattern, this is the minimum requirement for anatomy analysis in low- and high-resolution. The T-R cycles may be asymmetric, and one of the terms may even be missing (Fig. 23.1).

Recurrence is the fundamental characteristic of a cycle (Fig. 23.2). This pattern indicates that a regular mechanism controlled sedimentation. Its frequency allows the interpreter to speculate what could be that mechanism (long or shortterm - e.g., Pittet and Strasser 1998). Also, the frequency is inversely proportional to the hierarchy (e.g., Magalhães et al. 2016, Melo et al. 2020). Thus, the higher the frequency of a cycle candidate to be a sequence, the lower its hierarchy and the duration of its generating mechanisms (e.g., Pedrinha et al. 2015).

Since the recurrence of sequences does not establish a random pattern, the consequent upward trend is also an important criterion to be observed (e.g., Schlaich and Aigner 2017). Upward trends of stacking patterns occur due to short-term modulation by long-term processes in changes in the A/S ratio (accordion effect). The upward trend is fundamental for hierarchy. The vertical arrangement of stacking patterns that determine the high-frequency sequences is the basis for defining and constructing the stacking patterns of immediately 

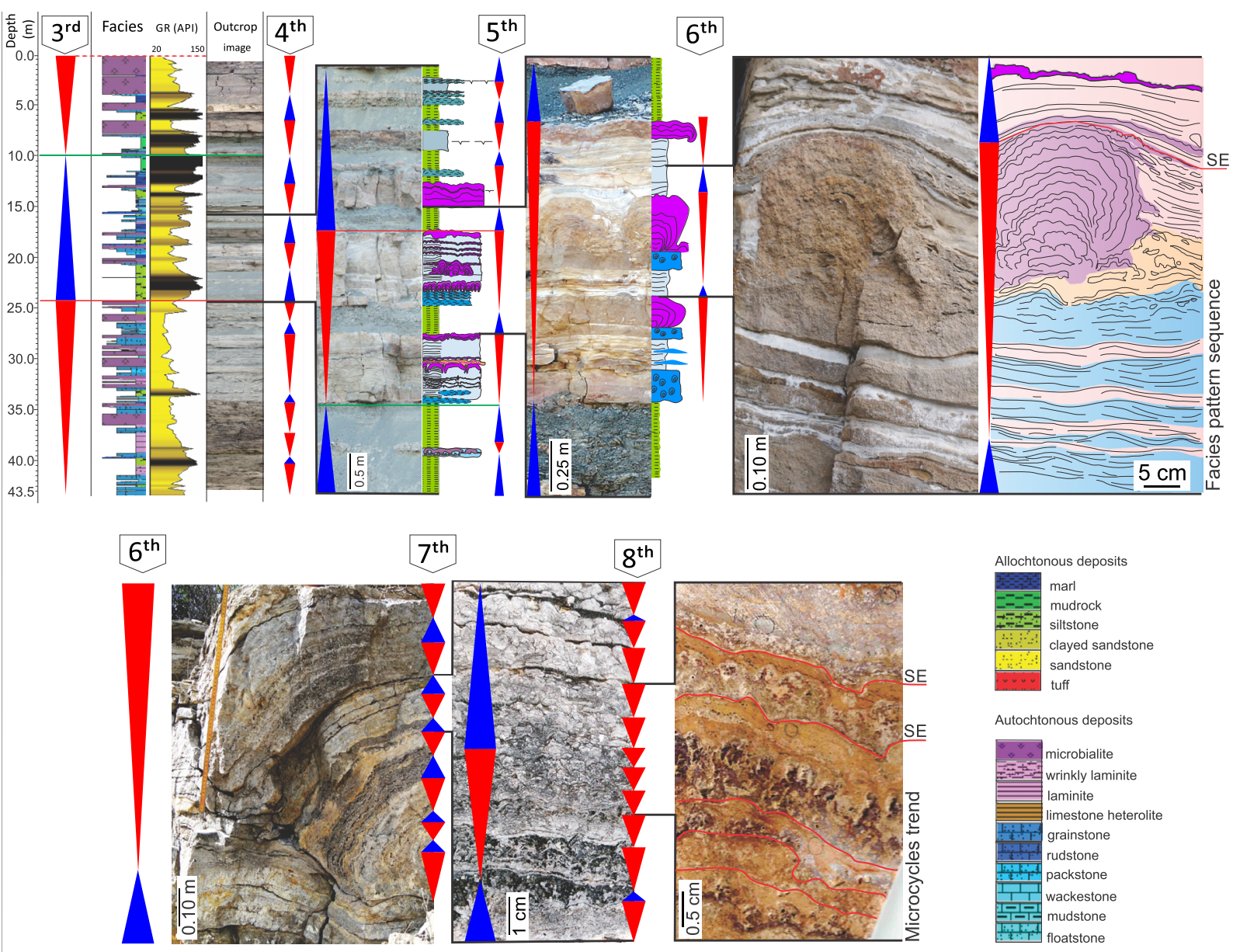

Figure 22. Cyclicity hierarchies observed in the Yacoraite Formation, Danian from the Salta Basin (Bento Freire 2012, Bunevich 2016, Bunevich et al. 2017). Stacking patterns are shown from the 3rd- to the 8th-order sequences, always composing superior hierarchies. Note the 7 th and 8 th order sequences, characterized by the rhythmic alternation of thickening and thinning trends during the stromatolite growth at a thin-section scale.

higher-order sequences (e.g., Turner et al.2012, Pedrinha et al. 2015, Gomes et al. 2020).

The change in any deposition trend is always marked by a stratigraphic surface (e.g., Catuneanu 2006). According to Magalhães et al. (2020), stratigraphic surfaces of any hierarchy are always anchored to the lowest rank. Lower rank surfaces may be a candidate to belong to a higher hierarchy. The fundamental importance of ranking stratigraphic surfaces is to determine the turning point of long-term transgressive or regressive trends and, thereby, to identify the boundaries that separate systems tracts from higher-ranking sequences.

The last criterion refers to the mappability of stacking patterns and their respective bounding stratigraphic surfaces. Within a given framework, mappability is greater the higher the sequence rank (Fig. 23.3 - e.g., Embry 2009, Magalhães et al. 2016, Melo et al. 2020). This criterion is based on the analysis related to time and the evolution of depositional topography. The higher-frequency sequences are formed in short periods, with a low potential to modify the inherited depositional topography. Thus, its preservation occurs only in local and discontinuous depocenters, resulting in poor correlations. This phenomenon is not only related to the amplitude but, above all, to the duration of base-level variation. Besides, as mentioned earlier, local variations in the $\mathrm{A} / \mathrm{S}$ ratio are common in short-term periods, decreasing the relative potential for long-distance correlations of high-resolution sequences. In relatively longer periods, the high potential for changes in the depositional topography and the general trend imposed on the $\mathrm{A} / \mathrm{S}$ ratio allow the development of lower-resolution sequences with considerable correlations over large areas.

The sequence mappability criterion reinforces that one-dimensional observations of depositional trends and sedimentation breaks in a single vertical section are not sufficient for stratigraphic analysis. However, even though the lateral correlation is mandatory for identifying a sequence of any hierarchy, sparse data can preclude it in the case of high-frequency sequences due to its limited spatial occurrence. For this reason, even if an individual high-frequency sequence is not mapped, their statistical representativeness in terms of vertical recurrence and trends analysis, for the construction of correlatable medium- and low-frequency sequences, guarantees an overall reliable sequential approach.

\section{Low-resolution sequence stratigraphy}

In general, sequence stratigraphy frameworks can be divided into low- and high-resolution (Fig. 19). 


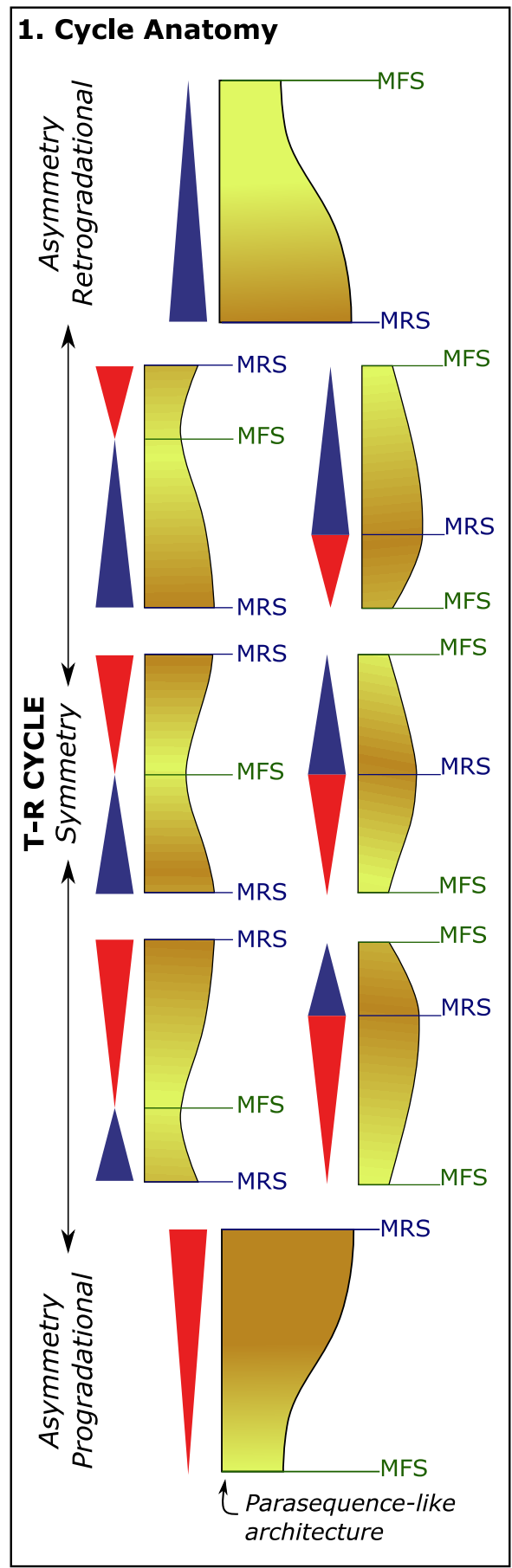

\section{Recurrence and Trends}

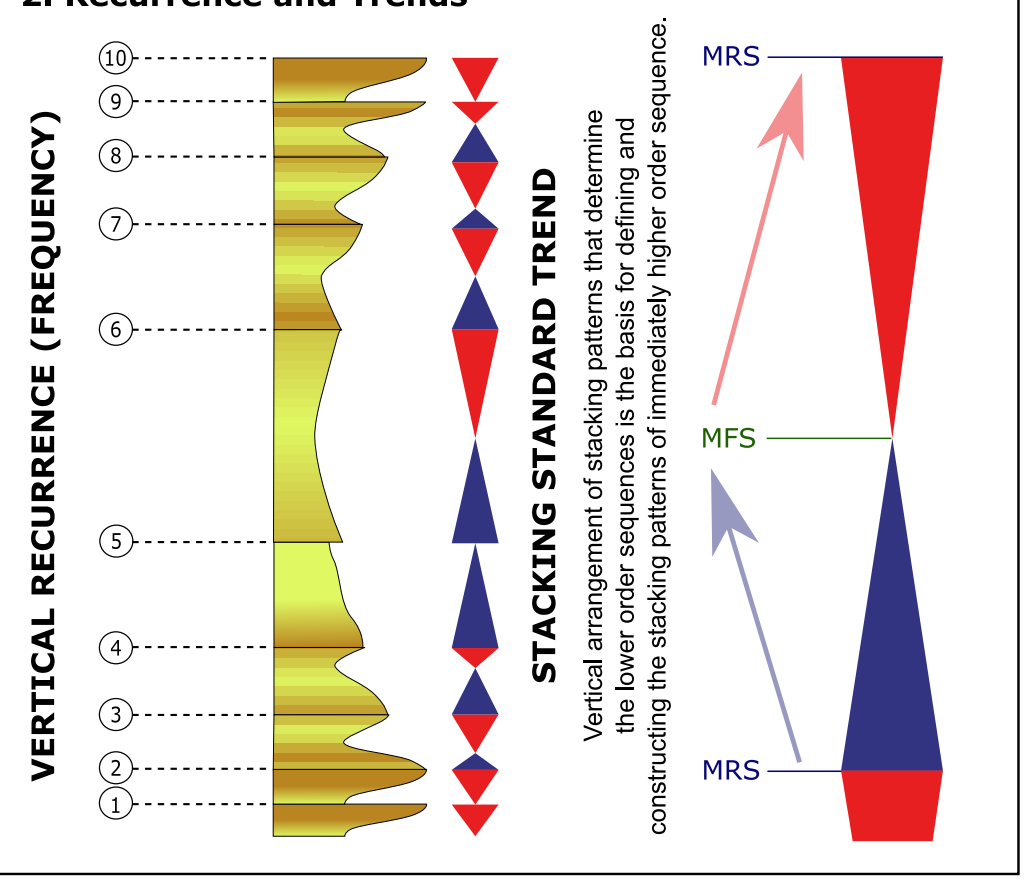

\section{Mapability}

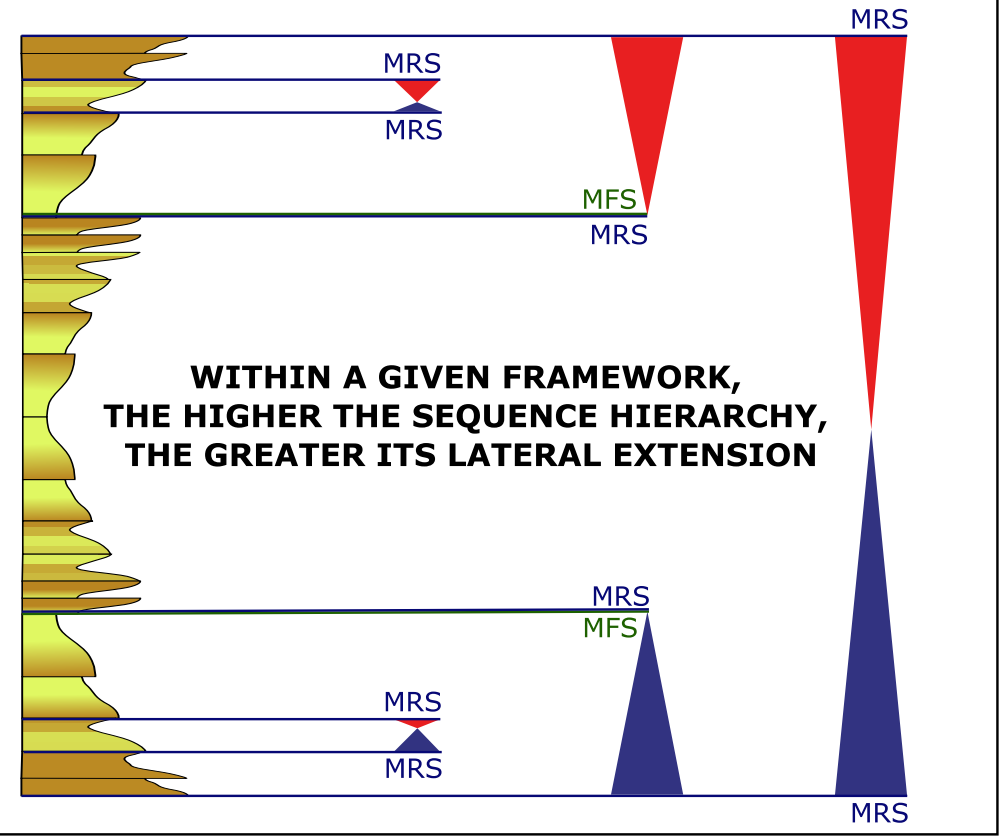

MFS: maximum flooding surface; MRS: maximum regressive surface.

Figure 23. Observable criteria for identifying sequences in the hierarchical framework: (1) Different architectures (cycle anatomy) of T-R cycles (modified from Zecchin 2007 and Catuneanu and Zecchin 2013). (2) Vertical recurrence of individual cycles and trends in the cycles stacking pattern (modulation of the smallest by the highest hierarchy). (3) The lateral extension (mappability) of the stacking patterns and stratigraphic surfaces, within a given framework, that is more significant the higher is the hierarchy.

The low-resolution is related to the definition of the regional stratigraphic framework, which involves basin- and seismic-scale analysis.

First-order sequences are consensually interpreted as corresponding to endogenous basin formation processes that compose a global supercontinent cycle (e.g., Woodcock 2004, Allen et al. 2015; Fig. 24). In a "polyphasic" basin, the record of each evolution phase, related to a specific subsidence mechanism, corresponds to a first-order sequence.
Second-order sequences correspond to the record of the main paleogeographic changes in the balance between accommodation and sediment supply related to basin scale (e.g., Catuneanu 2006). These paleogeographic changes are generally expressed in major transgressions and regressions within the stratigraphic evolution of any basin. Their origin is closely associated with regional and global tectonic processes (e.g., Catuneanu and Eriksson 1999, Eriksson et al. 2005). However, on this scale, the influence of long-term 


\section{SUPERCONTINENTAL (WILSON) CYCLE}

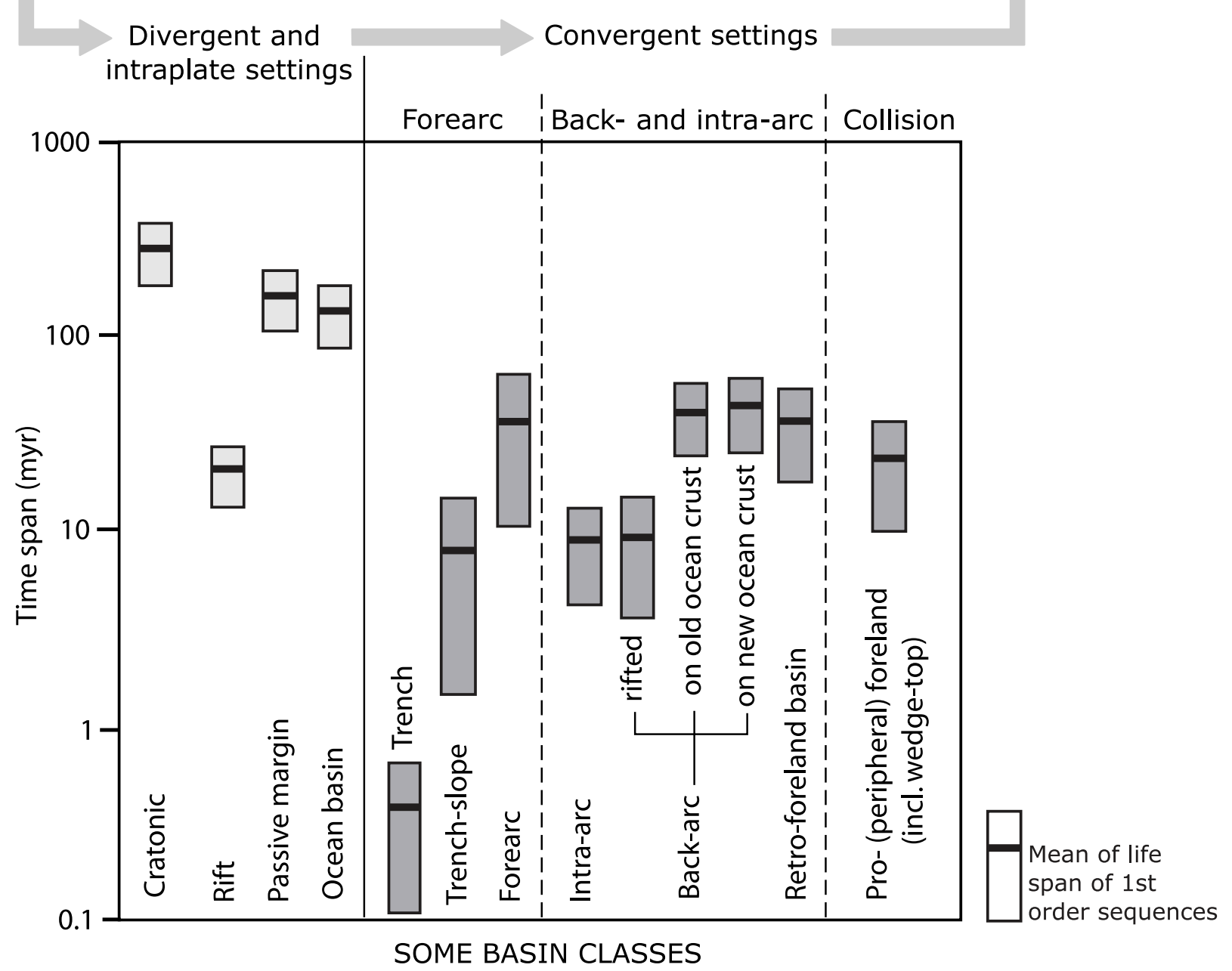

Source: modified from Woodcock (2004).

Figure 24. Origin and longevity of first-order sequences (related to the subsidence mechanisms) within the supercontinental Wilson cycle.

climate processes (e.g., greenhouse-icehouse cycles) cannot be neglected.

Melo et al. (2020) presented an example of a low-resolution stratigraphic framework for the Potiguar Basin, located on the Brazilian equatorial margin (Fig. 25). The tectonic phases (rift, post-rift, and drift) of this basin evolved during the opening of the South Atlantic Ocean and are classified as first-order sequences. Melo et al. (2020) defined two second-order sequences within the drift phase, which correspond to the most considerable paleogeographic changes in the basin scale for this interval. In the lower sequence, from Albian to late Campanian, the authors interpreted five third-order sequences mainly based on seismic data (Fig. 26).

The seismic-scale cycles (Fig. 19) correspond to the sequences interpreted from the alternation of seismic reflection termination patterns, whose relationship with depositional timelines offered the first tests for sequence stratigraphy (e.g., Vail et al. 1977, Galloway 1989). In general, seismic-scale cycles are considered third-order sequences (e.g., Melo et al. 2020). Although this definition is partially inconsistent, since it depends on data acquisition and processing techniques, the stratigraphic units imaged by seismic are always intermediate between the resolution of the sedimentary basin fill and the outcrop and core scale. These cycles are probably generated by the combination of tectonic (regional and global) and climatic controls, both influencing the eustatic pulse (e.g., Strasser et al. 2000).

The success of seismic stratigraphy in the oil industry is associated with the effective prediction of reservoirs and seals. The principles and practice of sequence stratigraphy were mainly built from the evolution of studies on seismic scale to recognize sequences, systems tracts, and stratigraphic surfaces (Fig. 27). Several general principles developed by the Exxon group in the 1970s are still in use in sequence stratigraphy. However, adjustments on the "seismic sequences" concept were improved in other scales, especially in the definition of high-frequency sequences associated with outcrop analysis, cores, and well logs data, generally attributed to high-resolution stratigraphy (e.g., Magalhães et al. 2016, Catuneanu and Zecchin 2013, Magalhães et al. 2020).

\section{High-resolution sequence stratigraphy}

High-resolution stratigraphy is traditionally related to the scale that exceeds seismic resolution, being determined in 


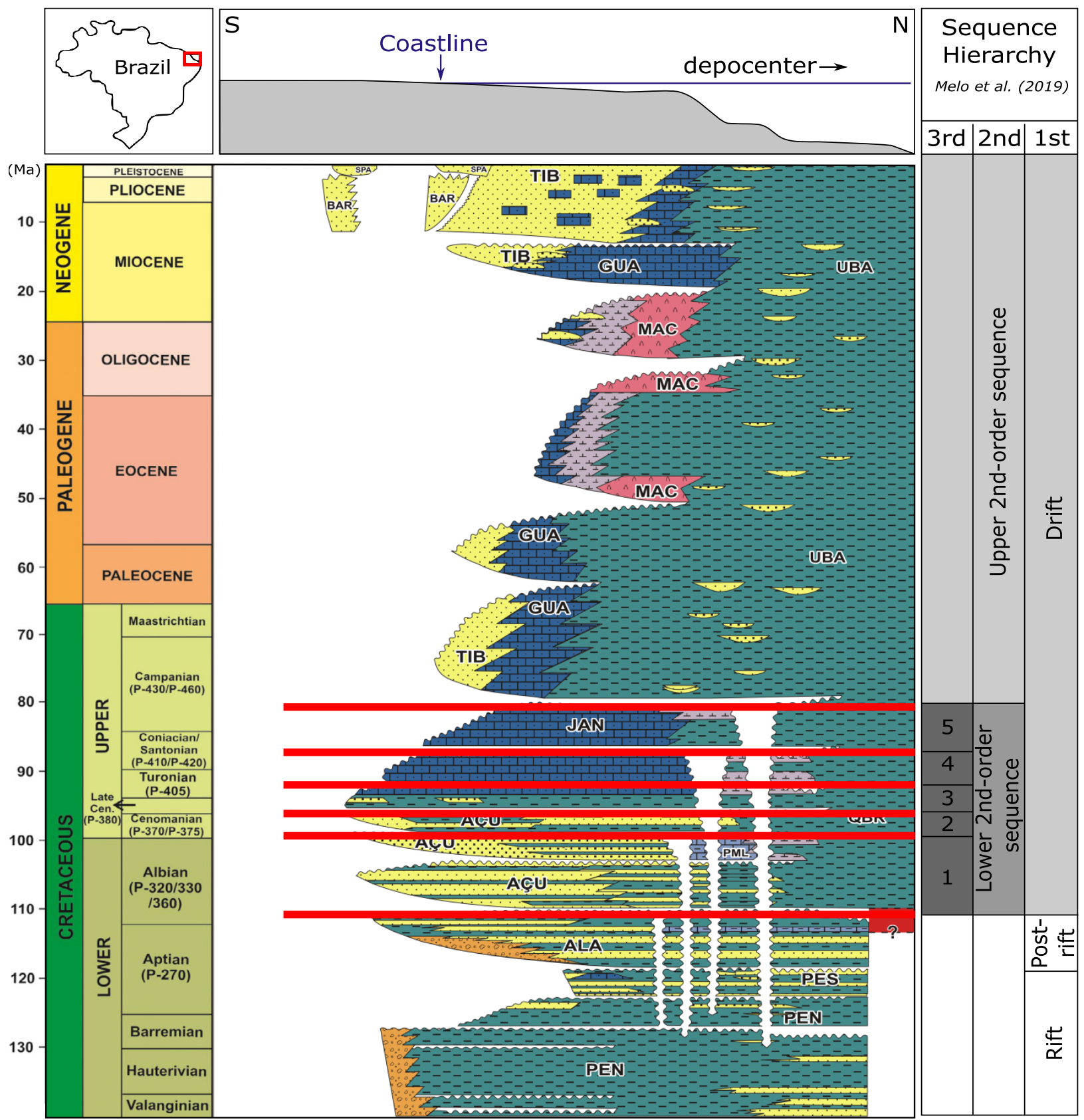

AÇU: Açu Formation; PML: Ponta do Mel Formation; JAN: Jandaíra Formation; QBR: Quebradas Formation.

Source: modified from Pessoa Neto et al. (2007).

Figure 25. Stratigraphic chart of the Potiguar Basin illustrating the proposed sequence hierarchy (Melo et al. 2020). The phases of tectonic evolution are first-order sequences. The drift phase is subdivided into two second-order sequences. The lower second-order sequence, from Albian to Campanian, is subdivided into five third-order sequences.

cores, well logs, and outcrops (e.g., Mitchum and Van Wagoner 1991). Some examples are presented by: Silveira (2020), in a deltaic deposit of Lajas Formation (Fig. 4); Magalhães et al. (2016), in estuarine strata of Tombador Formation (Fig. 21); Bento Freire (2012), Bunevich (2016), Bunevich et al. (2017), and Gomes et al. (2020), in lacustrine carbonate from Yacoraite Formation (Fig. 22); and Melo et al. (2020), in a fluvial interval of Açu Formation (Fig. 26).

For the oil industry, the applied high-resolution sequence stratigraphy is undoubtedly very relevant for reservoir geology (e.g., Zecchin and Catuneanu 2015). Magalhães et al. (2020) presented an extensive review, explaining in detail the high-resolution sequence stratigraphy methodology applied to reservoir zonation and characterization, showing how it better defines the critical heterogeneities that control the fluid flow observed during oil and gas production.

In general, the effort to standardize and define stratigraphic sequence orders (e.g., Catuneanu et al.2011, Catuneanu 2019a, 2019b, Magalhães et al. 2020) has shown that the methodology of sequence stratigraphy is independent of scale and the resolution of the data available. The stratigraphic record can be organized in sequences with an ordered pattern. At each observation scale, the building blocks are represented by sequences of different hierarchical levels (Catuneanu 2019b). 


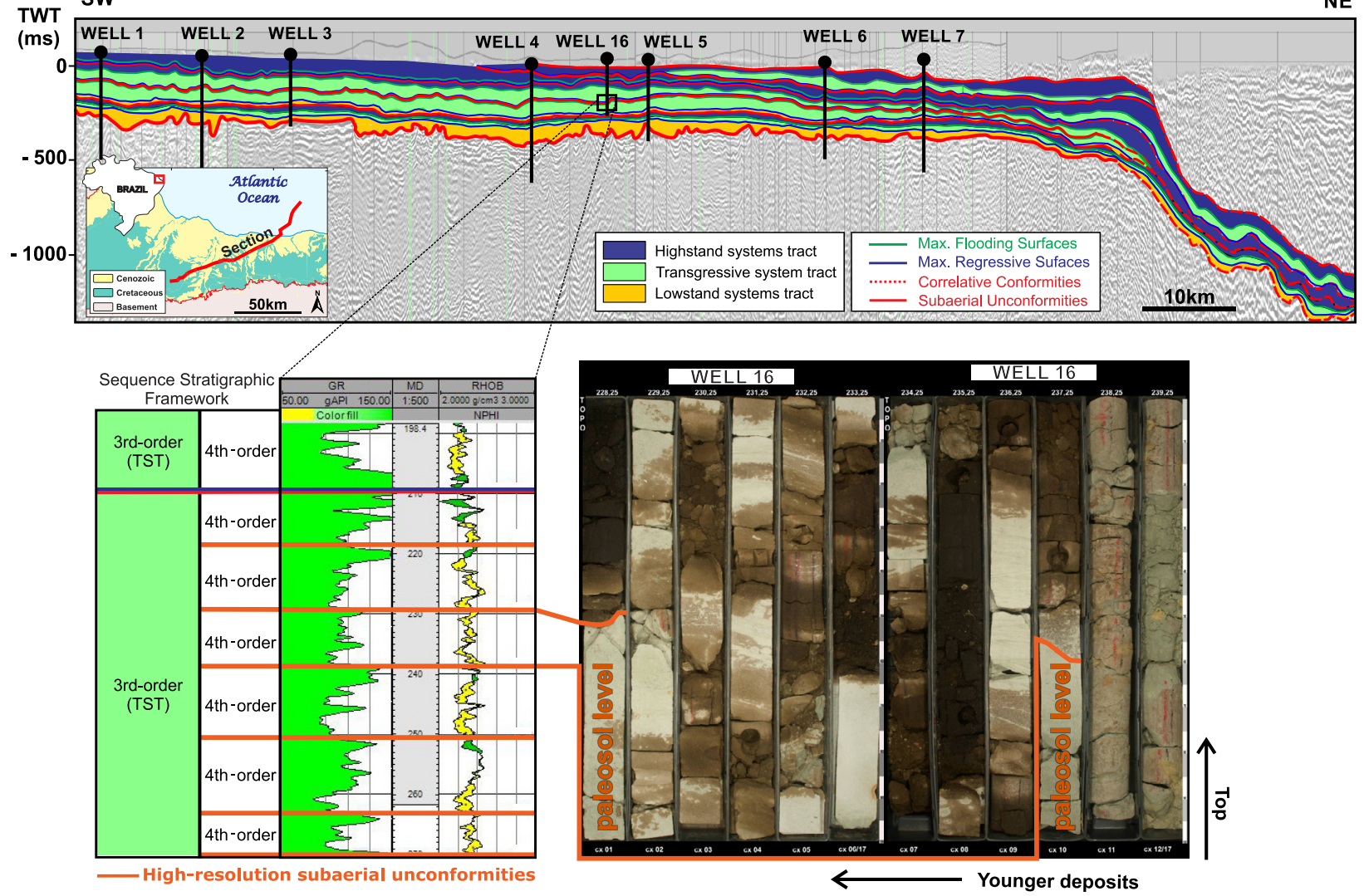

Source: modified from Melo et al. (2020).

Figure 26. Third- and fourth-order sequences from the Potiguar Basin (modified from Melo et al. 2020). A strike-oriented seismic section showing the sequences unconformity boundaries (red lines). Below, a closer view of well data showing the high-frequency fourth-order sequences identified in fluvial systems, bound by subaerial unconformities placed at the top of paleosols (detailed in core data).

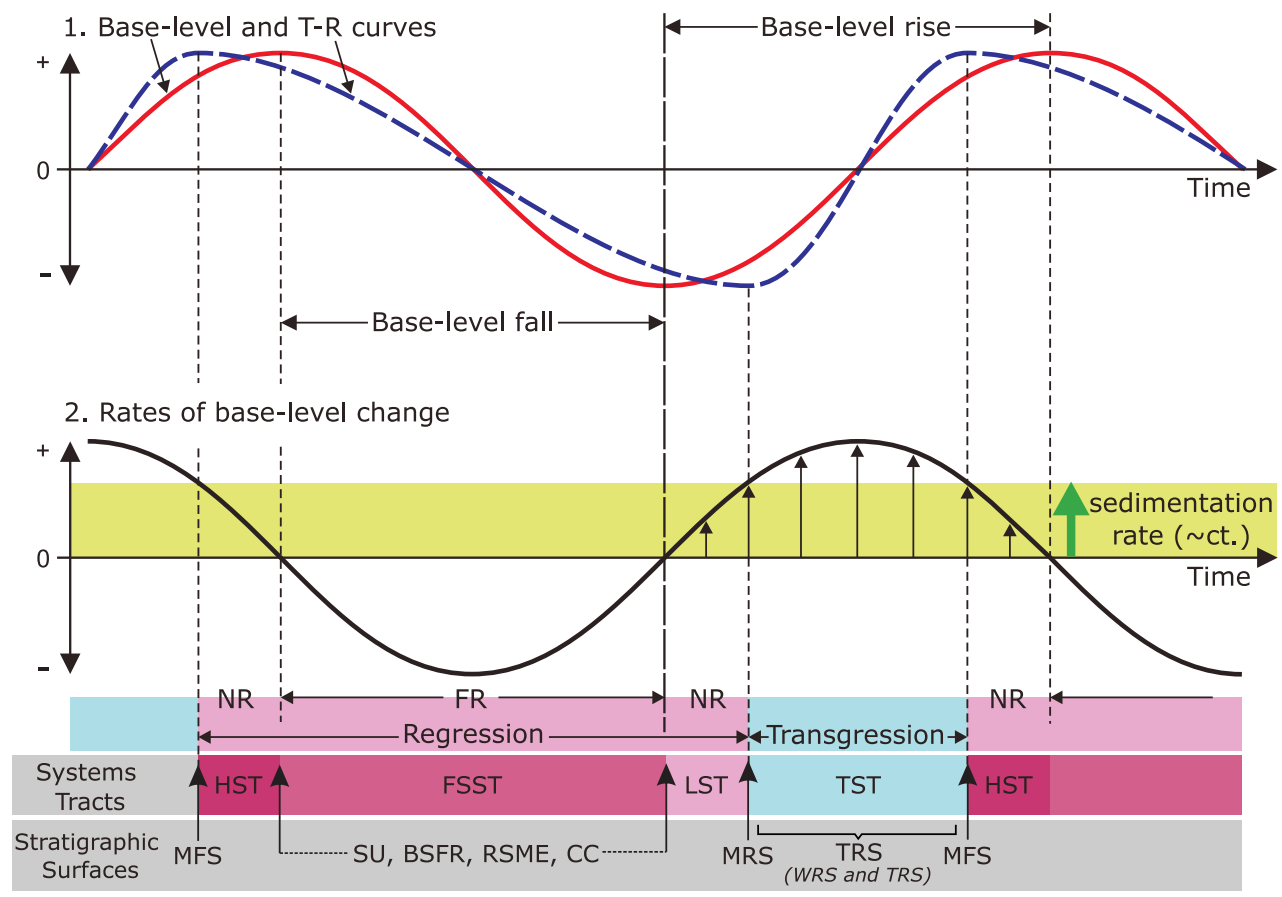

FR: forced regression; NR: normal regression; HST: highstand systems tract; FSST: falling-stage systems tract; LST: lowstand systems tract; TST: transgressive systems tract; MFS: maximum flooding surface; SU: subaerial unconformity; BSFR: basal surface of forced regression; RSME: regressive surface of marine erosion; CC: correlative conformity; MRS: maximum regressive surface; TRS: transgressive ravinement surfaces; WRS: wave-ravinement surface; TRS: tidal-ravinement surface. Source: modified from Catuneanu 2006.

Figure 27. System tracts and stratigraphic surfaces development in response to base-level changes as a function of time (modified from Catuneanu 2006). Above, base-level and transgressive-regressive (T-R) curves, and below, rates of base-level change and sedimentation rate. All sequence stratigraphic surfaces and system tracts can be defined with these curves. These definitions are perfectly adaptable for the seismic interpretation of sequences (especially in basins with the continental shelf and slope physiography). Adaptations are necessary for sequences above and below seismic resolution. 
According to Schlager (2004), since stratigraphic sequences are essentially shaped by the relationship between the rates of accommodation and the sediment supply, and both have fractal properties, it is not surprising that the resulting sequence record inherits this fractal attribute.

A relevant discussion about the fractal nature of stratigraphic sequences (Schlager, 2004) is related to the concept of depositional system. Some authors argue that the sequence architecture is largely invariable in scale and, therefore, changes in the systems tracts must be observed at all scales (e.g., Catuneanu 2019a, 2019b). Zecchin et al. (2017), for instance, differentiate sequences from sedimentological cycles using the concept of depositional systems. For these authors, sedimentological cycles occur within the same depositional system, whereas sequences encompass different systems, usually of greater thickness and duration.

It should be considered that, in a low-resolution scale involving large stratigraphic units, changes in depositional systems are easily perceived by the dominance of specific facies associations over others, either in vertical profile or in seismic data. Thus, facies changes in the depositional systems should be simply interpreted as the corresponding local record of the long-distance migration of the systems tracts toward the depocenter or toward the source area. In a high-resolution framework, even though high-frequency cycles promote paleogeographic changes involving different depositional systems, the extreme variations in facies associations may not necessarily be generated or preserved all over the basin as high-resolution stacking patterns. This issue refers to the previous discussion of Frankenstein models (see item "General Problem on Conceptual Depositional System"). The recognition of the transition from one depositional system to another would be more assured by observing the stacking trend of higher-resolution sequences enclosed within a single lower-resolution sequence. After all, the vertical trend is the main component for elaborating a hierarchical stratigraphic framework (Fig. 23).

In summary, the interpreter must always mitigate the proposal that imposes the condition of changing depositional systems to grant a stratigraphic value to the sedimentary succession, thus defining "sequences". In a high-resolution framework, the change in the depositional system is dependent on three factors:

- the location of the section containing the high-resolution sequences in relation to the shoreline - either nearby, where the system transitions occur more frequently, or faraway (extremely continental or deep sea), where vertically the systems tend to remain the same;

- how subordinated are the amplitudes in accommodation of short- and long-term geological processes;

- how detailed the high-resolution sequences are.

Thus, although changes in depositional systems are not seen in many contexts (e.g., fluvial - Melo et al.2020; Fig. 26) and scales (e.g., $5^{\text {th }}$ to $8^{\text {th }}$-order sequences - Bunevich et al. 2017; Fig. 22), some cyclical records are validly representative terms of the high-resolution framework, as they present all the observable criteria for the identification of sequences
(Fig. 23). In these cases, naming cyclical entities using geographic terms (system tracts) may not be appropriate, and the term "facies tracts" (e.g., Matenco and Haq 2020) is an alternative to compose high-frequency sequences.

Regarding genesis, it is known that short-term tectonic and deformational processes, which occur during the development of individual faults and folds (e.g., Raja Gabaglia 1991, Dickinson et al. 1994, Matenco and Haq 2020), can affect the parameters of accommodation and sediment supply for the development of high-frequency sequences. This is, undoubtedly, a field to be further explored by stratigraphic research. However, climate change is probably the chief mechanism for the origin of most of the cyclicity observed in outcrops and cores. In this sense, cyclostratigraphy has been used to investigate periodic climatic processes, potentially responsible for the genesis of the various observable cycles in the geological record (e.g., Wu et al. 2013; Fig. 16). Using this approach at different ages and depositional contexts, a growing number of cases have consistently demonstrated the relationship between high-frequency cyclical successions and climatic/astronomical processes (Hilgen et al. 2015), which fully conforms to the sequence stratigraphy approach (Schwarzacher 2000).

The detection of the preserved orbital signal in the stratigraphic record is achieved by a frequency analysis of the paleoclimatic proxies obtained in the section of interest. There are many proxies used in the cyclostratigraphic analysis, but the most frequent are:

- gamma-ray (e.g., Mendes 2005);

- magnetic properties of the rocks (e.g., Ellwood et al.2012);

- relative paleobatimetry defined by the facies succession (e.g., Olsen and Kent 1996);

- thickness of the layers (Tucker et al. 2009);

- color pattern of the sediments (e.g., Franco et al. 2011).

Li et al. (2019) presented an extensive and updated review of the concepts, methodological use, and interpretation of these main proxies in cyclostratigraphy.

Different mathematical techniques are also used for signal processing to determine and analyze a set of sequential data periodicity (Weedon 2003, Kodama and Hinnov 2014). Despite the mathematical solutions observed in many cyclostratigraphic works, the analyses of the temporal stratigraphic sign can be imprecise and subject to many misinterpretations if accurate geochronological information is not integrated. Thus, cyclostratigraphy is currently applied in conjunction with several other methods that assist the paleoenvironmental interpretation, improving the focus on paleoclimate proxies, but, above all, offering geochronological precision for temporal calibration.

Integrated stratigraphy is the combined application, for high-resolution stratigraphic analysis, of multiple stratigraphic subdisciplines, including cyclostratigraphy, biostratigraphy, magnetostratigraphy, chemostratigraphy, isotopic geochronology, especially when this practice is related to geological time (e.g., Coccioni et al. 2012, Hilgen et al. 2015). Once the astronomical signal detection is demonstrated, a temporal calibration with exceptional precision and resolution can be 
established. Hence, the climatic, oceanographic, sedimentary, biological, and diagenetic processes can be evaluated with higher accuracy than traditional geochronological approaches (Strasser et al. 2007). A refinement of the conceptual geological model for high-frequency paleogeographic and paleoecological variations applying integrated stratigraphic studies authorizes long-distance chronocorrelations between cyclical successions of different depositional systems and allows astronomical tuning by mathematical solutions (e.g., Hilgen et al. 2015; Fig. 28).

\section{FINAL REMARKS}

The advances in sequence stratigraphy have contributed mainly to the consolidation of applicable methodology to describe the observable record at different scales, defining sequences within a chronostratigraphic hierarchical structure (e.g., Catuneanu et al. 2011, Catuneanu 2019a, 2019b, Magalhães et al. 2020). However, sequence stratigraphy is still in a state of flux, and attempts to standardize the method should leave ample room for the evolution of concepts (Schlager 2010).

The experience accumulated in many years of research and application by Petrobras School of High-Resolution Stratigraphy (e.g., Raja Gabaglia 1991, Bento Freire 2012, De Gasperi and Catuneanu 2014, Pedrinha et al. 2015, RoemersOliveira et al. 2015, Magalhães et al. 2016, Bunevich et al. 2017, Melo et al. 2020, Gomes et al. 2020, Magalhães et al. 2020, Silveira 2020) reinforces the importance of the interdependence between description and interpretation for the development of sequence stratigraphy principles and practice.
Supported by the conceptual basis available in the literature, especially for the understanding of stratigraphic preservation, it is here proposed an integrated analysis of four observable criteria that identify and rank sequences at all scales permitted by the available data: cycle anatomy, recurrence, vertical trends, and mappability (Fig. 23). These characteristics imply the existence of a regular cyclical mechanism that controls their generation and preservation.

The interpretative approach advocated here considers that allogenic mechanisms are the major reference to explain cyclicity in the generation and preservation of sedimentary deposits (e.g., Miall 2017), providing the principles for understanding the regularity of stratigraphic record at multiple scales (accordion effect), their hierarchical nature and, ultimately, supporting any sequential analysis. The association of the fundamental concepts of sequence stratigraphy with updated knowledge of tectonic (e.g., Matenco and Haq 2020) and climatic processes (e.g., Strasser et al. 2007), and their interrelationships with eustasy (e.g., Sames et al.2020), supports a workflow that starts from the recognition of elementary units to their stratigraphic clusters, which occur organized in vertical succession and horizontal correlations (Fig. 29).

In summary, for theoretical and practical purposes, the concept of sequence is definitively connected to allogenic mechanisms. Even if the autogenic factor necessarily occurs for the genesis of any sedimentary deposit, the eventual and isolated internal changes in the sedimentary system are not sufficient to explain the generation of stratigraphic cyclical units that make up a hierarchical and predictive framework. In other words, it is not recommended to define a sequence based only on the cycle pattern observed in a single vertical

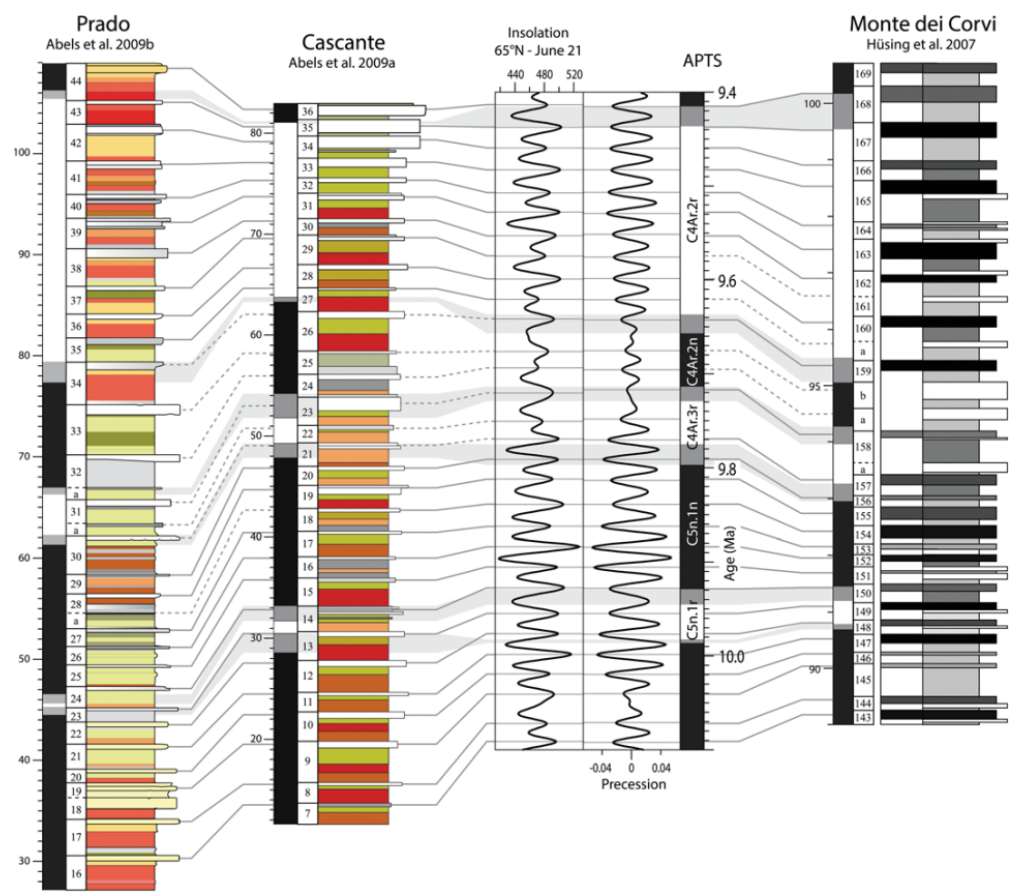

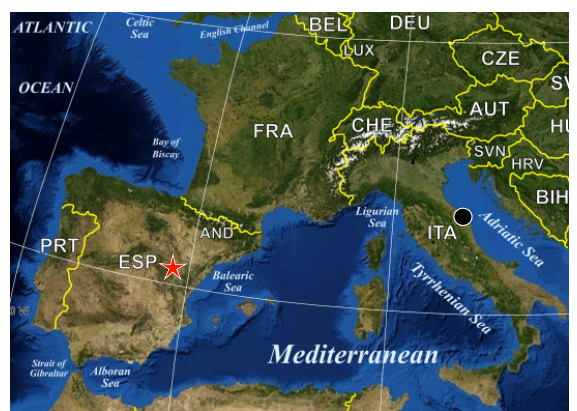

Continental Sections - $\star$ Legend Prado

Legend Cascante

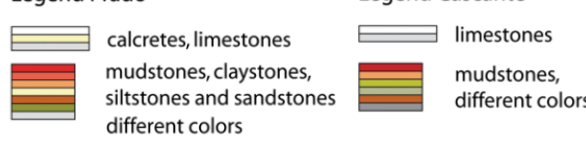

Marine Section -

Legend Monte dei Corvi

limestones

sapropels (prominent

to faint)

marls (distinctness)

Source: modified from Hilgen et al. (2015).

Figure 28. High-resolution cyclostratigraphic correlations (at precession-scale) and tuning of the continental sections of Prado and Cascante (Spain) and the marine section of Monte dei Corvi (Italy). The correlations and tuning are tightly constrained by magnetostratigraphy in all sections. 


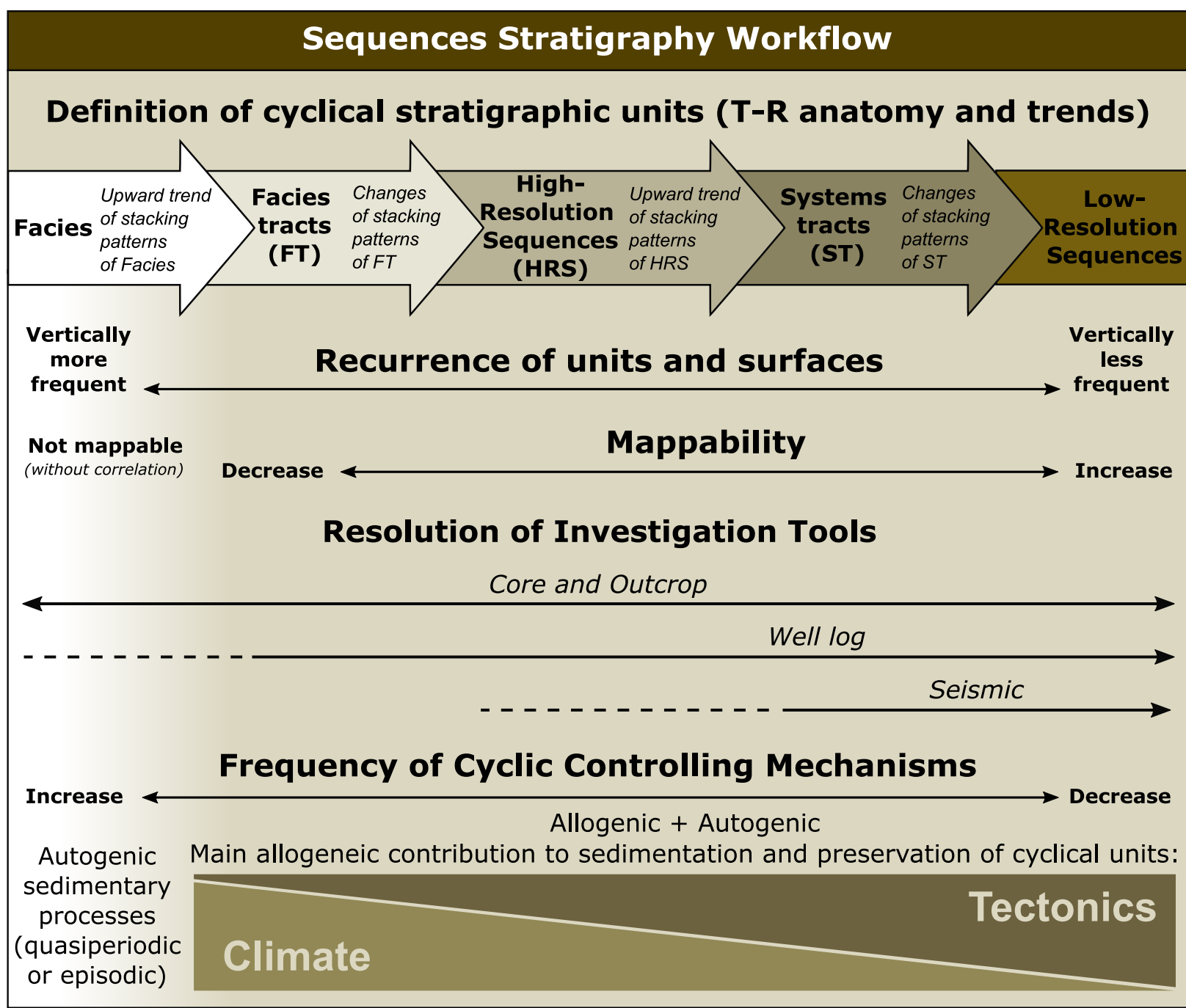

Figure 29. Sequence stratigraphy workflow that starts from recognizing elementary units to their stratigraphic clusters, that occur organized in mappable vertical successions. Stratigraphic stacking patterns that define T-R cycle anatomies can be observed at different scales, depending on the resolution of the investigation tool. Except for sedimentary facies, produced purely by autogenic processes, all recurring stacking patterns that make up the hierarchical framework, are a product of the autogenic and allogenic processes interaction. The highest stratigraphic frequencies are composed of facies tracts, whose changes in stacking patterns give rise to high-resolution sequences. These sequences tend to have less mappability and are predominantly controlled by climatic processes modulated by tectonics. System tracts can be recognized as an organization of high-resolution sequences in an upward trend of stacking patterns, with the preponderant representation of given facies associations and arrangements. Changes in system tracts make up low-resolution sequences. These units have wider mappability and are controlled predominantly by tectonics, modeled at different intensities by the climate.

section, even if that arrangement is similar to the T-R cycle. Such cycles alone do not offer a prediction, precisely because they have several possibilities of origin. Thus, recurrence, vertical trends, and mappability are fundamental features to define sequence, and compose a hierarchical framework. When mappability is not demonstrable on a very detailed scale due to lack of data, other parameters coherent with lower-resolution scale characterization guarantee the prediction of the sequential analysis.

Conceptual models elaborated with a hierarchical stratigraphic framework, which incorporate the knowledge of geological processes - from low to high frequency - in the generation and preservation of sequences - from lowto high-resolution - , reduce the inaccuracies and contradictions of their counterparts based on simple sedimentary accumulation, which traditionally considers the existence of fully preserved three-dimensional depositional systems (the "Frankenstein models"). The methodological gain is materialized in more realistic representations, ensuring objective results in predicting vertical recurrence and lateral correlation of stratigraphic units. This analysis is fundamentally useful in its application in the oil industry (e.g., Melo et al. 2020, Magalhães et al. 2020).

Relevant advances in stratigraphic research are currently identified within the sequence stratigraphy context, especially in the high-resolution analysis. High-resolution tectono-stratigraphy is an example of a study field not yet explored. Moreover, few studies have combined the progress in high-resolution sequence stratigraphy with the integrated stratigraphy/ cyclostratigraphy. The methodology of high resolution instigates the comprehension of the geological evolution of the basin filling, considering sedimentary evolution complexity 
related to the generation, preservation, and to the measurements and meaning of the innumerable temporal gaps. This perspective allows to:

- Identify and correlate multi-scale sequences through the direct description of the rock record (stacking patterns and stratigraphic surfaces);

- Characterize the high-resolution hierarchy;

- Dispose of a stratigraphic framework to define the principal deposition controlling mechanisms (and time scales involved) through the quantitative analysis of frequencies of sedimentary parameters (proxies).

The definition of the main controlling factors enables a better estimation of the rates of generation and preservation of any sedimentary succession. Consequently, a hierarchical chronostratigraphic framework can be developed, with sequences correlated to varying distances within a basin.
The methodological gain is the development of more robust conceptual models. In other words, advances in this research direction will reduce the inaccuracies of the purely qualitative sequential analysis and offer potential correlations for the vertical analysis of the cyclostratigraphy.

\section{ACKNOWLEDGMENTS}

The authors would like to thank the support of Petrobras and their permission to publish this paper, and the other members of the Petrobras School of High-Resolution Sequence Stratigraphy for helpful discussions. Special thanks to Dora Atman, Matheus Kuchenbecker, Julio Sanglard, Rodrigo Bunevich, Anderson Melo, Miguel Silveira, and Tatiana Oliveira. We are also grateful to the reviewers and editors for their valuable comments and suggestions, which helped improve the manuscript.

\section{ARTICLE INFORMATION}

Manuscript ID: 20200106. Received on: 10/05/2020. Approved on: 02/18/2021.

D.F. conceived the presented idea, wrote the first draft, prepared the figures, and made changes to the manuscript according to the reviewers' suggestions. G.G., A.M., and C.S. conceived the presented idea and improved the manuscript through corrections and suggestions.

Competing interests: The authors declare no competing interests.

\section{REFERENCES}

Ager D.V. 1993. The new catastrophism: the importance of the rare event in geological history. Cambridge, Cambridge University Press, 231 p.

Allen P.A. 2008. From landscapes into geological history. Nature, 451(7176):274-276. https://doi.org/10.1038/nature06586

Allen P.A., Eriksson P.G., Alkmim F.F., Betts P.G., Catuneanu O., Mazumder R., Meng Q. Young G.M. 2015. Classification of basins, with special reference to Proterozoic examples. Geological Society of London, Memoirs, 43:5-28. https://doi.org/10.1144/M43.2

Auchter N.C., Romans B.W., Hubbard S.M., Daniels B.G., Scher H.D., Buckley W. 2020. Intrabasinal sediment recycling from detrital strontium isotope stratigraphy. Geology, 48(10):992-996. https://doi.org/10.1130/ G47594.1

Bállico M.B., Scherer C.M.S., Mountney N.P., Souza E.G., Reis A.D., Raja Gabaglia G.P., Magalhães A.J.C. 2017. Sedimentary cycles in a Mesoproterozoic aeolian erg-margin succession: Mangabeira Formation, Espinhaço Supergroup, Brazil. Sedimentary Geology, 349:1-14. https://doi. org/10.1016/j.sedgeo.2016.12.008

Barrell J. 1917. Rhythms and the measurements of geologic time. GSA Bulletin, 28(1):745-904. https://doi.org/10.1130/GSAB-28-745

Bento Freire E. 2012. Caracterização estratigráfica em alta resolução das sequências carbonáticas de origem microbial do intervalo paleocênico da Formação Yacoraite (Sequência Balbuena IV) na região de Salta - Argentina. MSc Thesis, Universidade Federal do Rio de Janeiro, Rio de Janeiro, 224 p.

Bhattacharya J.P. 1993. The expression and interpretation of marine flooding surfaces and erosional surfaces in core; examples from the Upper Cretaceous Dunvegan Formation in the Alberta foreland basin. In: Posamentier H.W., Summerhayes C.P., Haq B.U., Allen G.P. (eds.). Sequence stratigraphy and facies associations. Special Publication, v. 18, p. 125-160. International Association of Sedimentologists. https://doi. org/10.1002/9781444304015.ch8

Bohacs K.M., Carroll A.R., Neal J.E., Mankiewicz P.J. 2000. Lake-basin type, source potential, and hydrocarbon character: an integrated-sequencestratigraphic-geochemical framework. In: Gierlowski-Kordesch E.H., Kelts
K.R. (eds.). Lake basins through space and time. AAPG Studies in Geology, 46. Tulsa, p. 3-34. https://doi.org/10.1306/St46706C1

Bunevich R.B. 2016. Caracterização e interpretação bioarquitetural de microbialitos lacustres da sequência Balbuena IV (Daniano), bacia de Salta - Argentina. MSc Thesis, Universidade Federal do Rio de Janeiro, Rio de Janeiro, $173 \mathrm{p}$

Bunevich R.B., Borghi L., Raja Gabaglia G.P., Terra G.J.S., Bento Freire E., Lykawka R., Fragoso D.G.C. 2017. Microbialitos da Sequência Balbuena IV (Daniano), Bacia de Salta, Argentina: caracterização de intrabioarquiteturas e de microciclos. Pesquisas em Geociências, 44(2):177. https://doi. org/10.22456/1807-9806.78270

Castelltort S., Van Den Driessche J. 2003. How plausible are high-frequency sediment supply-driven cycles in the stratigraphic record? Sedimentary Geology, 157(1-2):3-13. https://doi.org/10.1016/S0037-0738(03)00066-6

Catuneanu O. 2006. Principles of sequence stratigraphy. Amsterdam, Elsevier, $375 \mathrm{p}$.

Catuneanu O.2019a. Model-independent sequence stratigraphy.Earth-Science Reviews, 188:312-388. https://doi.org/10.1016/j.earscirev.2018.09.017

Catuneanu O. 2019b. Scale in sequence stratigraphy. Marine and Petroleum Geology, 106:128-159. https://doi.org/10.1016/j.marpetgeo.2019.04.026

Catuneanu O., Abreu V., Bhattacharya J.P., Blum M.D., Dalrymple R.W., Eriksson P.G., Fielding C.R., Fisher W.L., Galloway W.E., Gibling M.R., Giles K.A., Holbrook J.M., Jordan R., Kendall C.G.St.C., Macurda B., Martinsen O.J., Miall A.D., Neal J.E., Nummedal D., Pomar L., Posamentier H.W., Pratt B.R., Sarg J.F., Shanley K.W., Steel R.J., Strasser A., Tucker M.E., Winker C. 2009. Towards the standardization of sequence stratigraphy. Earth-Science Reviews, 92(1-2):1-33. https://doi.org/10.1016/j.earscirev.2008.10.003

Catuneanu O., Bhattacharya J.P., Blum M.D., Dalrymple R.W., Eriksson P.G., Fielding C.R., Fisher W.L., Galloway W.E., Gianolla P., Gibling M.R., Giles K.A., Holbrook J.M., Jordan R., Kendall C.G. St. C., Macurda B., Martinsen O.J., Miall A.D., Nummedal D., Posamentier H.W., Pratt B.R., Shanley K.W., Steel R.J., Strasser A., Tucker M.E. 2010. Sequence stratigraphy: common ground after three decades of development. First Break, 28:21-34. 
Catuneanu O., Eriksson P.G. 1999. The sequence stratigraphic concept and the Precambrian rock record: an example from the 2.7-2.1 Ga Transvaal Supergroup, Kaapvaal craton. Precambrian Research, 97(3-4):215-51. https://doi.org/10.1016/S0301-9268(99)00033-9

Catuneanu O., Galloway W.E., Kendall C.G.S.t.C., Miall A.D., Posamentier H.W., Strasser A., Tucker M.E. 2011. Sequence Stratigraphy: Methodology and Nomenclature. Newsletters on Stratigraphy, 44(3):173-245. https://doi. org/10.1127/0078-0421/2011/0011

Catuneanu O., Sweet A.R., Miall A.D. 1999. Concept and styles of reciprocal stratigraphies: Western Canada foreland basin. Terra Nova, 11(1):1-8. https://doi.org/10.1046/j.1365-3121.1999.00222.x

Catuneanu O., Zecchin M. 2013. High-resolution sequence stratigraphy of clastic shelves II: Controls on sequence development. Marine and Petroleum Geology, 39(1):26-38. https://doi.org/10.1016/j.marpetgeo.2012.08.010

Coccioni R., Sideri M., Bancalà G., Catanzariti R., Frontalini F., Jovane L., Montanari A., Savian J. 2012. Integrated stratigraphy (magneto-, bioand chronostratigraphy) and geochronology of the Palaeogene pelagic succession of the Umbria-Marche Basin (central Italy). Geological Society of London, Special Publications, 373(1):111-131. https://doi.org/10.1144/ SP373.4

Coe A.L., Bosence D.W.J., Church K.D., Flint S.S., Howell J.A., Wilson R.C.L. (Eds.). 2003. The Sedimentary Record of Sea-Level Change. Cambridge, Cambridge University Press, $288 \mathrm{p}$.

Conrad C.P. 2013. The solid Earth's influence on sea level. GSA Bulletin, 125(7-8):1027-1052. https://doi.org/10.1130/B30764.1

Currie B.S. 1997. Sequence stratigraphy of nonmarine Jurassic-Cretaceous rocks, central Cordilleran foreland-basin system. GSA Bulletin, 109(9):12061222. https://doi.org/10.1130/0016-7606(1997)109<1206:SSONJC >2. 3.CO;2

De Gasperi A., Catuneanu O. 2014. Sequence stratigraphy of the Eocene turbidite reservoirs in Albacora field, Campos Basin, offshore Brazil. AAPG Bulletin, 98(2):279-313. https://doi.org/10.1306/07031312117

Dickinson W.R., Soreghan G.S., Giles K.A. 1994. Glacio-Eustatic Origin of Permo-Carboniferous Stratigraphic Cycles: Evidence from the Southern Cordilleran Foreland Region. In: Dennison J.M., Ettensohn F.R. (Eds.). Tectonic and Eustatic Controls on Sedimentary Cycles. Tulsa, SEPM Society for Sedimentary Geology, p. 25-34.

Dietrich P., Ghienne J.-F., Lajeunesse P., Normandeau A., Deschamps R., Razin P. 2018. Deglacial sequences and glacio-isostatic adjustment: Quaternary compared with Ordovician glaciations. Geological Society of London, Special Publications, 475(1):149-179. https://doi.org/10.1144/ SP475.9

Dott R.H., Jr. 1983. Episodic sedimentation - how normal is average? How rare is rare? Does it matter? Journal of Sedimentary Petrology, 53:5-23.

Dott R.H., Jr. 2014. Laurence L. Sloss and the Sequence Stratigraphy Revolution. GSA Today, 24(3):24-26.

Einsele G., Seilacher A. (eds.). 1982. Cyclic and event stratification. Berlin, Springer International, $536 \mathrm{p}$.

Ellwood B.B., Brett C.E., Tomkin J.H., Macdonald W.D. 2012. Visual identification and quantification of Milankovitch climate cycles in outcrop: an example from the Upper Ordovician Kope Formation, Northern Kentucky. Geological Society of London, Special Publications, 373(1):341353. https://doi.org/10.1144/SP373.2

Embry A.F. 1993. Transgressive-regressive (T-R) sequence analysis of the Jurassic succession of the Sverdrup Basin, Canadian Arctic Archipelago. Canadian Journal of Earth Sciences, 30(2):301-20. https://doi.org/10.1139/ e93-024

Embry A.F. 1995. Sequence boundaries and sequence hierarchies: problems and proposals. Norwegian Petroleum Society Special Publications, 5:1-11. https://doi.org/10.1016/S0928-8937(06)80059-7

Embry A.F. 2009. Practical Sequence Stratigraphy. Canadian Society of Petroleum Geologists, $79 \mathrm{p}$.

Embry A.F., Johannessen E.P. 1992. T-R sequence stratigraphy, facies analysis and reservoir distribution in the uppermost Triassic-Lower Jurassic succession, western Sverdrup Basin, Arctic Canada. In: Vorren T.O., Bergsager E., Dahl-Stamnes O.A., Holter E., Johansen B., Lie E., Lund
T.B. (Eds.). Arctic Geology and Petroleum Potential, p. 121-146. Special Publication 2. Norwegian Petroleum Society.

Eriksson P.G., Catuneanu O., Els B.G., Bumby A.J., van Rooy J.L., Popa M. 2005. Kaapvaal craton: changing first- and second-order controls on sea level from c. 3.0 Ga to 2.0 Ga. Sedimentary Geology, 176(1-2):121-48. https://doi.org/10.1016/j.sedgeo.2004.12.010

Fairbridge R.W. 1961. Eustatic changes in sea level. Physics and Chemistry of the Earth, 4:99-185. https://doi.org/10.1016/0079-1946(61)90004-0

Fantinel L.M. 2005. O ensino de mapeamento geológico no Centro de Geologia Eschwege, Diamantina - MG: analise de três décadas de práticas de campo (1970-2000). PhD Thesis, Universidade Estadual de Campinas, Campinas, $258 \mathrm{p}$.

Faria D.L.P., Tadeu dos Reis A., Gomes de Souza O. 2017. Threedimensional stratigraphic-sedimentological forward modeling of an Aptian carbonate reservoir deposited during the sag stage in the Santos basin, Brazil. Marine and Petroleum Geology, 88:676-695. https://doi.org/10.1016/j. marpetgeo.2017.09.013

Fick C., Manica R., Toldo Junior E.E. 2017. Autogenic influence on the morphology of submarine fans: an approach from 3D physical modelling of turbidity currents. Brazilian Journal of Geology, 47(3):345-368. https://doi. org/10.1590/2317-4889201720170066

Fischer A.G. 1981. Climatic oscillations in the biosphere. Biotic Crises in Ecological and Evolutionary Time, 103-131. https://doi.org/10.1016/ B978-0-12-519640-6.50012-0

Franco D.R., Hinnov L.A., Ernesto M. 2011. Spectral analysis and modeling of microcyclostratigraphy in late Paleozoic glaciogenic rhythmites, Paraná Basin, Brazil. Geochemistry, Geophysics, Geosystems, 12(9):1-15. https://doi. org/10.1029/2011GC003602

Frazier D.E. 1974. Depositional-Episodes: Their Relationship to the Quaternary Stratigraphic Framework in the Northwestern Portion of the Gulf Basin. Bureau of Economic Geology Circular, 74(1):1-28.

Frodeman R. 1995. Geological reasoning: Geology as an interpretive and historical science. GSA Bulletin, 107(8):960-968. https://doi. org/10.1130/0016-7606(1995)107<0960:GRGAAI>2.3.CO;2

Galloway W.E. 1989. Genetic Stratigraphic Sequences in Basin Analysis I: Architecture and Genesis of Flooding-Surface Bounded Depositional Units. AAPG Bulletin, 73(2):125-142. https://doi. org/10.1306/703C9AF5-1707-11D7-8645000102C1865D

Gautney J.R. 2018. New world paleoenvironments during the Last Glacial Maximum: Implications for habitable land area and human dispersal. Journal of Archaeological Science: Reports, 19:166-176. https://doi.org/10.1016/j. jasrep.2018.02.043

Gomes J.P.B., Bunevich R.B., Tonietto S.N., Alves D.B., Santos J.F., Whitaker F.F. 2020. Climatic signals in lacustrine deposits of the Upper Yacoraite Formation, Western Argentina: Evidence from clay minerals, analcime, dolomite and fibrous calcite. Sedimentology, 67(5):2282-2309. https://doi. org/10.1111/sed.12700

Hajek E.A., Straub K.M. 2017. Autogenic Sedimentation in Clastic Stratigraphy. Annual Review of Earth and Planetary Sciences, 45(1):681-709. https://doi.org/10.1146/annurev-earth-063016-015935

Hardie L.A., Bosellini A., Goldhammer R.K. 1986. Repeated subaerial exposure of subtidal carbonate platforms, Triassic, northern Italy: Evidence for high frequency sea level oscillations on a $10^{4}$ year scale. Paleoceanography, 1(4):447-457. https://doi.org/10.1029/PA001i004p00447

Hilgen F.J., Hinnov L.A., Abdul Aziz H., Abels H.A., Batenburg S., Bosmans J.H.C., de Boer B., Hüsing S.K., Kuiper K.F., Lourens L.J., Rivera T., Tuenter E., Van de Wal R.S.W., Wotzlaw J.-F., Zeeden C. 2015. Stratigraphic continuity and fragmentary sedimentation: the success of cyclostratigraphy as part of integrated stratigraphy. Geological Society, London, Special Publications, 404(1):157-197. https://doi.org/10.1144/SP404.12

Hinnov L.A. 2013. Cyclostratigraphy and its revolutionizing applications in the earth and planetary sciences. GSA Bulletin, 125(11-12):1703-1734. https://doi.org/10.1130/B30934.1

Holbrook J., Miall A.D. 2020. Time in the Rock: A field guide to interpreting past events and processes from siliciclastic stratigraphy. Earth Science Reviews, 203:103121 https://doi.org/10.1016/j.earscirev.2020.103121 
Holz M., Vilas-Boas D.B., Troccoli E.B., Santana V.C., Vidigal-Souza P.A. 2017. Conceptual Models for Sequence Stratigraphy of Continental Rift Successions. In: Montenari M. (ed.). Advances in Sequence Stratigraphy, 2, p. 119-186. Amsterdam, Elsevier. https://doi.org/10.1016/ bs.sats.2017.07.002

House M.R. 1995. Orbital forcing timescales: an introduction. Geological Society of London, Special Publications, 85(1):1-18. https://doi. org/10.1144/GSL.SP.1995.085.01.01

Howell J.A., Flint S.S. 1996. A model for high resolution sequence stratigraphy within extensional basins. In: Howell J.A., Aitken J.F. (eds.). High Resolution Sequence Stratigraphy: Innovations and Applications, Geological Society of London Special Publications, 104(1):129-137. https:// doi.org/10.1144/GSL.SP.1996.104.01.09

Hunt D., Tucker M.E. 1992. Stranded parasequences and the forced regressive wedge systems tract: deposition during base-level fall. Sedimentary Geology, 81(1-2):1-9. https://doi.org/10.1016/0037-0738(92)90052-S

Jerolmack D.J., Paola C. 2010. Shredding of environmental signals by sediment transport. Geophysical Research Letters, 37(19):L19401. https:// doi.org/10.1029/2010GL044638

Jervey M.T. 1988. Quantitative geological modeling of siliciclastic rock sequences and their seismic expression. In: Wilgus C.K., Hastings B.S., Kendall C.G.S.t.C., Posamentier H.W., Ross C.A., Van Wagoner J.C. (eds.). Sea level Changes - an integrated approach, 42, p. 47-69. Society of Economic Paleontologists and Mineralogists Special Publication, Tulsa. https://doi. org/10.2110/pec.88.01.0047

Johnson J.G., Murphy M.A. 1984. Time-rock model for Siluro-Devonian continental shelf, western United States. Geological Society of America Bulletin, 95(11):1349-1359. https://doi.org/10.1130/0016-7606(1984)95\%3C13 49:TMFSCS\%3E2.0.CO;2

Jouzel J., Masson-Delmotte V., Cattani O., Dreyfus G., Falourd S., Hoffmann G., Minster B., Nouet J., Barnola J.M., Chappellaz J., Fischer H., Gallet J.C., Johnsen S., Leuenberger M., Loulergue L., Luethi D., Oerter H., Parrenin F., Raisbeck G., Raynaud D., Schilt A., Schwander J., Selmo E., Souchez R., Spahni R., Stauffer B., Steffensen J.P., Stenni B., Stocker T.F., Tison J.L., Werner M., Wolff E.W. 2007. Orbital and Millennial Antarctic Climate Variability over the Past 800,000 Years. Science, 317(5839):793-796. https://doi.org/10.1126/science.1141038

Khani H.F., Back S. 2015. The influence of differential sedimentary loading and compaction on the development of a deltaic rollover. Marine and Petroleum Geology, 59:136-149. https://doi.org/10.1016/j. marpetgeo.2014.08.005

Kidder D.L., Worsley T.R. 2010. Phanerozoic Large Igneous Provinces (LIPs), HEATT (Haline Euxinic Acidic Thermal Transgression) episodes, and mass extinctions. Palaeogeography, Palaeoclimatology, Palaeoecology, 295(1-2):162-191. https://doi.org/10.1016/j.palaeo.2010.05.036

Kodama K.P.,HinnovL.A.2014.RockMagnetic Cyclostratigraphy. Chichester: John Wiley \& Sons, 165 p. https://doi.org/10.1002/9781118561294

Kuchle J., Scherer C.M.S. 2010. Sismoestratigrafia de bacias rifte: técnicas, métodos e sua aplicação na Bacia de Recôncavo. Boletim de Geociências da Petrobras, 18(2):33-60.

Li M., Huang C., Ogg J., Zhang Y., Hinnov L., Wu H., Chen Z.-Q., Zou Z. 2019. Paleoclimate proxies for cyclostratigraphy: Comparative analysis using a Lower Triassic marine section in South China. Earth-Science Reviews, 189:125-146. https://doi.org/10.1016/j.earscirev.2019.01.011

Li P., Tang D., Shi X., Jiang G., Zhao X., Zhou X., Wang X., Chen X. 2018. Sunspot cycles recorded in siliciclastic biolaminites at the dawn of the Neoproterozoic Sturtian glaciation in South China. Precambrian Research, 315:75-91. https://doi.org/10.1016/j.precamres.2018.07.018

Magalhães A.J.C., Raja Gabaglia G.P., Fragoso D.G.C., Bento Freire E., Lykawka R., Arregui C.D., Silveira M.M.L., Carpio K.M.T., De Gasperi A., Pedrinha S., Artagão V.M., Terra G.J.S., Bunevich R.B., RoemersOliveira E., Gomes J.P., Hernández J.I., Hernández R.M., Bruhn C.H.L. 2020. High-resolution sequence stratigraphy applied to reservoir zonation and characterisation, and its impact on production performance - Shallow marine, downstream, and lacustrine carbonate settings. Earth-Science Reviews, 201:103325. https://doi.org/10.1016/j.earscirev.2020.103325

Magalhães A.J.C., Raja Gabaglia G.P., Scherer C.M.S., Bállico M.B., Guadagnin F., Bento Freire E., Silva Born L.R., Catuneanu O. 2016.
Sequence hierarchy in a Mesoproterozoic interior sag basin: from basin fill to reservoir scale, the Tombador Formation, Chapada Diamantina Basin, Brazil. Basin Research, 28(3):393-432. https://doi.org/10.1111/bre.12117

Martinius A.W., Elfenbein C., Keogh K.J. 2014. Applying accommodation versus sediment supply ratio concepts to stratigraphic analysis and zonation of a fluvial reservoir. In: Martinius A.W., Ravnas R., Howell J.A., Steel R.J., Wonham J.P. (eds.). From Depositional Systems to Sedimentary Successions on the Norwegian Continental Margin, 46, p. 101-125. London,International Association of Sedimentologists Special Publication. https://doi. org/10.1002/9781118920435.ch4

Matenco L.C., Haq B.U. 2020. Multi-scale depositional successions in tectonic settings. Earth-Science Reviews, 200:102991. https://doi. org/10.1016/j.earscirev.2019.102991

Melo A.H., Andrade P.R.O., Magalhães A.J.C., Fragoso D.G.C., Lima-Filho F.P. 2020. Stratigraphic evolution from the early Albian to late Campanian of the Potiguar Basin, Northeast Brazil: An approach in seismic scale. Basin Research, 32(5):1054-1080. https://doi.org/10.1111/bre.12414

Mendes J.M.C. 2005. Análise da ciclicidade impressa no registro sedimentar da seção neo-aptiana / eocenomaniana (fm. Riachuelo) na bacia de sergipe-alagoas. Revista Brasileira de Geociências, 35:107-114. https://doi. org/10.25249/0375-7536.200535ETE107114

Miall A.D. 1996. The geology of fluvial deposits: sedimentary facies, basin analysis and petroleum geology. Berlin, Springer International, $582 \mathrm{p}$. https://doi.org/10.1007/978-3-662-03237-4

Miall A.D. 2010. The Geology of Stratigraphic Sequences. Berlin, Springer International, 522 p. https://doi.org/10.1007/978-3-642-05027-5

Miall A.D. 2015. Updating uniformitarianism: stratigraphy as just a set of 'frozen accidents.' Geological Society of London, Special Publications, 404(1):11-36. https://doi.org/10.1144/SP404.4

Miall A.D. 2016. Stratigraphy: A Modern Synthesis. Switzerland, Springer International, $454 \mathrm{p}$.

Miall A.D. 2017. Sequence stratigraphy and geologic time. In: Montenari M. (Ed.). Advances in Sequence Stratigraphy, 2, p. 59-83. Amsterdam, Elsevier. https://doi.org/10.1016/bs.sats.2017.06.001

Milankovitch M. 1941. Kanon der Erdbestrahlungen und seine Anwendung auf das Eiszeiten Problem. Special Publications of the Royal Serbian Academy, 633 p.

Mitchum R. M., Jr. 1977. Seismic stratigraphy and global changes of sea level, part 11: glossary of terms used in seismic stratigraphy. In: Payton C.E. (Ed.). Seismic Stratigraphy: Applications to Hydrocarbon Exploration, AAPG Memoir, 26, 205-212.

Mitchum R.M, Jr., Van Wagoner J.C. 1991. High-frequency sequences and their stacking patterns: sequence-stratigraphic evidence of high-frequency eustatic cycles. Sedimentary Geology, 70(2-4):131-160. https://doi. org/10.1016/0037-0738(91)90139-5

Muto T.,SteelR.J.2000. The accommodation concept in sequence stratigraphy: some dimensional problems and possible redefinition. Sedimentary Geology, 130(1-2):1-10. https://doi.org/10.1016/S0037-0738(99)00107-4

Nakagawa T., Iwamori H., Yanagi R., Nakao A. 2018. On the evolution of the water ocean in the plate-mantle system. Progress in Earth and Planetary Science, 5:51. https://doi.org/10.1186/s40645-018-0209-2

Nance R.D., Murphy J.B., Santosh M. 2014. The supercontinent cycle: A retrospective essay. Gondwana Research, 25(1):4-29. https://doi. org/10.1016/j.gr.2012.12.026

Neal J., Abreu V. 2009. Sequence stratigraphy hierarchy and the accommodation succession method. Geology, 37(9):779-782. https://doi. org/10.1130/G25722A.1

Ni H., Zheng Y., Mao Z., Wang Q. Chen R., Zhang L. 2017. Distribution, cycling and impact of water in the Earth's interior, National Science Review, 4(6):879-891. https://doi.org/10.1093/nsr/nwx130

Oliveira M.J., Carneiro C.D.R., Vecchia F.A.S., Baptista G.M.M. 2017. Ciclos climáticos e causas naturais das mudanças do clima. Terrae Didatica, 13(3):149-184. https://doi.org/10.20396/td.v13i3.8650958

OlsenP.E.,KentD.V.1996.MilankovitchclimateforcinginthetropicsofPangaea during the Late Triassic. Palaeogeography, Palaeoclimatology, Palaeoecology, 122(1-4):1-26. https://doi.org/10.1016/0031-0182(95)00171-9 
Payton C.E. 1977. Seismic Stratigraphy - Applications to Hydrocarbon Exploration. American Association of Petroleum Geologists. American Association of Petroleum Geologists Memoir, 26, 516 p.

Pedrinha S., Gabaglia G.P.R., Lykawka R., Brito D. 2015. Rastreabilidade de sequências de alta resolução ao longo da Sub-bacia de Métan-Alemania (Maastrichtiano da Bacia de Salta - Argentina): anatomia estratigráfica detalhada de um sistema lacustre sob influência de processos microbiais. Boletim de Geociências da Petrobras, 23(1-2).

Pessoa Neto O.C., Soares U.M., Silva J.G.F., Roesner E.H., Florencio C.P., Souza C.A.V. 2007. Bacia Potiguar. Boletim de Geociências da Petrobras, 15(2):357-369.

Pittet B., Strasser A. 1998. Long-distance correlations by sequence stratigraphy and cyclostratigraphy: examples and implications (Oxfordian from the Swiss Jura, Spain, and Normandy). Geologische Rundschau, 86(4):852-874. https://doi.org/10.1007/s005310050181

Posamentier H.W., Allen G.P. 1999. Siliciclastic sequence stratigraphyconcepts and applications. Concepts in sedimentology and paleontology, SEPM Society for Sedimentary Geology, Tulsa, 7, 210 p. https://doi. org/10.2110/csp.99.07

Posamentier H.W., Jervey M.T., Vail P.R. 1988. Eustatic controls on clastic deposition I - conceptual framework. In: Wilgus C.K., Hastings B.S., Kendall C.G.St.C., Posamentier H.W., Ross C.A., Van Wagoner J.C. (eds.). Sea level Changes: an integrated approach, v. 42, p. 110-124. Tulsa: Society of Economic Paleontologists and Mineralogists Special Publication.

Powell R.D., Cooper J.M. 2002. A glacial sequence stratigraphic model for temperate, glaciated continental shelves. In: Dowdeswell J.A., Cofaigh C.O. (Eds.). Glacier-Influenced Sedimentation on High-Latitude Continental Margins. Geological Society of London, Special Publications, 203(1):215-244. https://doi.org/10.1144/GSL.SP.2002.203.01.12

Raja Gabaglia G.P. 1991. Paleossismicidade e sedimentação: evidências no compartimento sul da Bacia do Recôncavo. Boletim de Geociências da Petrobras, 5(1):39-68.

Ray D.C., van Buchem F.S.P., Baines G., Davies A., Gréselle B., Simmons M.D., Robson C. 2019. The magnitude and cause of short-term eustatic Cretaceous sea-level change: A synthesis. Earth-Science Reviews, 197:102901. https://doi.org/10.1016/j.earscirev.2019.102901

Reading H.G., Levell B.K. 1996. Controls on the sedimentary rock record. In: Reading H.G. (Ed.). Sedimentary Environments: Processes, Facies and Stratigraphy, 3, p. 5-36. Oxford: Wiley-Blackwell.

Roemers-Oliveira E., Fernandes L.A., Bento Freire E., Simões L.S.A. 2015. Microbial filaments in stromatolites and laminites of Balbuena III Sequence (Maastrichtian/Danian) of Yacoraite Formation in MetánAlemania Sub-basin, Salta region, Argentina, and its alaeoenvironmental significance. Brazilian Journal of Geology, 45(3):399-413. https://doi. org/10.1590/2317-488920150030255

Rojo L.A., Marín D., Cardozo N., Escalona A., Koyi H. 2020. The influence of halokinesis on prograding clinoforms: Insights from the Tiddlybanken Basin, Norwegian Barents Sea. Basin Research, 32(5):979-1004. https:// doi.org/10.1111/bre.12411

Romans B.W., Castelltort S., Covault J.A., Fildani A., Walsh J.P. 2016. Environmental signal propagation in sedimentary systems across timescales. Earth-Science Reviews, 153:7-29. https://doi.org/10.1016/j. earscirev.2015.07.012

Sadler P. 1999. The influence of hiatuses on sediment accumulation rates,in On the Determination of Sediment Accumulation Rates. GeoResearch Forum, 5:15-40.

Sames B., Wagreich M., Conrad C.P., Iqbal S. 2020. Aquifer-eustasy as the main driver of short-term sea-level fluctuations during Cretaceous hothouse climate phases. Geological Society of London, Special Publications, 498:9-38. https://doi.org/10.1144/SP498-2019-105

Sames B., Wagreich M., Wendler J.E., Haq B.U., Conrad C.P., MelinteDobrinescu M.C., Hu X., Wendler I., Wolfgring E., Yilmaz I.Ö., Zorina S.O. 2016. Review: Short-term sea-level changes in a greenhouse world - A view from the Cretaceous. Palaeogeography, Palaeoclimatology, Palaeoecology, 441(3):393-411. https://doi.org/10.1016/j.palaeo.2015.10.045

Schlager W. 2004. Fractal nature of stratigraphic sequences. Geology, 32(3):185-188. https://doi.org/10.1130/G20253.1
Schlager W. 2010. Ordered hierarchy versus scale invariance in sequence stratigraphy. International Journal of Earth Sciences, 99(S1):139-151. https://doi.org/10.1007/s00531-009-0491-8

Schlager W. (ed.). 2005. Carbonate sedimentology and sequence stratigraphy. Tulsa, SEPM Concepts in Sedimentology and Paleontology, 8, 200 p. https://doi.org/10.2110/csp.05.08

Schlaich M., Aigner T. 2017. Facies and integrated sequence stratigraphy of an Epeiric Carbonate Ramp Succession: Dhruma Formation, Sultanate of Oman. The Depositional Record, 3(1):92-132. https://doi.org/10.1002/dep2.28

Schumm S.A. 1977. The fluvial system. New York, John Wiley \& Sons, 338 p.

Schwarzacher W. 1993. Cyclostratigraphy and the Milankovitch theory. Amsterdam, Developments in Sedimentology, Elsevier, 52, 225 p.

Schwarzacher W. 2000. Repetitions and cycles in stratigraphy. Earth-Science Reviews, 50(1-2):51-75. https://doi.org/10.1016/S0012-8252(99)00070-7

Shanley K.W., McCabe P.J. 1994. Perspectives on the sequence stratigraphy of continental strata. AAPG Bulletin, 78(4):544-568.

Silveira M.M.L. 2020. Análisis estratigráfico secuencial de alta resolución y modelado geológico $3 d$ en secciones sedimentarias transicionales y continentales del Jurásico Inferior a Medio del sector sur de la Cuenca Neuquina como análogo en la caracterización de reservorios de hidrocarburos. $\mathrm{PhD}$ Thesis, Universidad Nacional de La Plata, La Plata, 294 p.

Sloss L.L. 1963. Sequences in the cratonic interior of North America. GSA Bulletin, 74(2):93-114. https://doi.org/10.1130/0016-7606(1963)74[93:SI TCIO]2.0.CO;2

Sloss L.L., Krumbein W.C., Dapples E.C. 1949. Integrated facies analysis. In: Longwell C. (Ed.) Sedimentary facies in geologic history. GSA Memoirs, 39, p. 91-124. New York. https://doi.org/10.1130/MEM39-p91

Steinhauff D., Walker K.R. 1995. Recognizing exposure, drowning, and "missed beats"; platform-interior to platform-margin sequence stratigraphy of Middle Ordovicianlimestones,EastTennessee.JournalofSedimentaryResearch,65(2b):183207.https://doi.org/10.1306/D4268211-2B26-11D7-8648000102C1865D

Strasser A. 2015. Hiatuses and condensation: an estimation of time lost on a shallow carbonate platform. The Depositional Record, 1(2):91-117. https:// doi.org/10.1002/dep2.9

Strasser A., Hilgen F.J., Heckel P.H. 2007. Cyclostratigraphy concepts, definitions, and applications. Newsletters on Stratigraphy, 42(2):75-114. https://doi.org/10.1127/0078-0421/2006/0042-0075

Strasser A., Hillgärtner H., Hug W., Pittet B. 2000. Third-order depositional sequences reflecting Milankovitch cyclicity. Terra Nova, 12(6):303-311. https://doi.org/10.1046/j.1365-3121.2000.00315.x

Strasser A., Pittet B., Hillgärtner H., Pasquier J.B. 1999. Depositional sequences in shallow carbonate-dominated sedimentary systems: concepts for a high-resolution analysis. Sedimentary Geology, 128(3-4):201-221. https://doi.org/10.1016/S0037-0738(99)00070-6

Takashima R., Nishi H., Huber B., Leckie R.M. 2006. Greenhouse World and the Mesozoic Ocean. Oceanography, 19(4):82-92. https://doi. org/10.5670/oceanog.2006.07

Trampush S.M., Hajek E.A., Straub K.M., Chamberlin E.P. 2017. Identifying autogenic sedimentation in fluvial-deltaic stratigraphy: Evaluating the effect of outcrop-quality data on the compensation statistic. Journal of Geophysical Research: Earth Surface, 122(1):91-113. https://doi. org/10.1002/2016JF004067

Tucker M.E., Gallagher J., Leng M.J. 2009. Are beds in shelf carbonates millennial-scale cycles? An example from the mid-Carboniferous of northern England... Sedimentary Geology, 214(1-4):19-34. https://doi. org/10.1016/j.sedgeo.2008.03.011

Turner B.R., Armstrong H.A., Wilson C.R., Makhlouf I.M. 2012. High frequency eustatic sea-level changes during the Middle to early Late Ordovician of southern Jordan: Indirect evidence for a Darriwilian Ice Age in Gondwana. Sedimentary Geology, 251-252:34-48. https://doi. org/10.1016/j.sedgeo.2012.01.002

Vail P.R. 1992. The evolution of seismic stratigraphy and the global sea-level curve. In: Dott R.H., Jr (Ed.). Eustasy: The Historical Ups and Downs of a Major Geological Concept. Boulder, GSA Memoir, 180, p. 83-92. https:// doi.org/10.1130/MEM180-p83 
Vail P.R., Mitchum Jr., R.M., Thompson III S. 1977. Seismic Stratigraphy and Global Changes of Sea Level, Part 4: Global Cycles of Relative Changes of Sea Level. In: Payton C.E. (Ed.). Seismic Stratigraphy - Applications to Hydrocarbon Exploration. AAPG Memoir, 26, 83-97.

Van Wagoner J.C., Mitchum R.M., Campion K.M., Rahmanian V.D. 1990. Siliciclastic Sequence Stratigraphy in Well Logs, Cores, and Outcrops: Concepts for High-Resolution Correlation of Time and Facies. American Association of Petroleum Geologists, 55 p. https://doi.org/10.1306/Mth7510

Van Wagoner J.C., Posamentier H.W., Mitchum R.M., Jr., Vail P.R., Sarg J.F., Loutit T.S., Hardenbol J. 1988. An overview of the fundamentals of sequence stratigraphy and key definitions. In: Wilgus C.K., Hastings B.S., Kendall C.G.S.t.C., Posamentier H.W., Ross C.A., Van Wagoner J.C. (Eds.). Sea level Changes - an integrated approach, 42, p. 39-45. Tulsa, Society of Economic Paleontologists and Mineralogists Special Publication. https:// doi.org/10.2110/pec.88.01.0039

Waelbroeck C., Labeyrie L., Michel E., Duplessy J.C., McManus J.F., Lambeck K., Balbon E., Labracherie M. 2002. Sea-level and deep water temperature changes derived from benthic foraminifera isotopic records. Quaternary Science Reviews, 21(1-3):295-305. https://doi.org/10.1016/ S0277-3791(01)00101-9

Weedon G.P. 2003. Time-Series Analysis and Cyclostratigraphy: Examining Stratigraphic Records of Environmental Cycles. Cambridge, Cambridge University Press, 259 p. https://doi.org/10.1017/CBO9780511535482

Wilgus C.K., Hastings B.S., Kendall C.G.S.t.C., Posamentier H.W., Ross C.A., Van Wagoner J.C. (Eds.). 1988. Sea level changes: an integrated approach. Tulsa, Society of Economic Paleontologists and Mineralogists Special Publication, 42, $407 \mathrm{p}$.
Woodcock N.H. 2004. Life span and fate of basins. Geology, 32(8):685-688. https://doi.org/10.1130/G20598.1

Worsley T.R., Nance D., Moody J.B. 1984. Global tectonics and eustasy for the past 2 billion years. Marine Geology, 58(3-4):373-400. https://doi. org/10.1016/0025-3227(84)90209-3

Wright N.M., Seton M., Williams S.E., Whittaker J.M., Müller R.D. 2020. Sea-level fluctuations driven by changes in global ocean basin volume following supercontinent break-up. Earth-Science Reviews, 208:103293. https://doi.org/10.1016/j.earscirev.2020.103293

Wright V.P., Marriott S.B. 1993. The sequence stratigraphy of fluvial depositional systems: the role of floodplain sediment storage. Sedimentary Geology, $\mathbf{8 6}(3-4): 203-210 . \quad$ https://doi. org/10.1016/0037-0738(93)90022-W

Wu H., Zhang S., Hinnov L.A., Jiang G., Feng Q. Li H., Yang T. 2013. Timecalibrated Milankovitch cycles for the late Permian. Nature Communications, 4(1):2452. https://doi.org/10.1038/ncomms3452

Zecchin M. 2007. The architectural variability of small-scale cycles in shelf and ramp clastic systems: The controlling factors. Earth-Science Reviews, 84(1-2):21-55. https://doi.org/10.1016/j.earscirev.2007.05.003

Zecchin M., Catuneanu O. 2015. High-resolution sequence stratigraphy of clastic shelves III: Applications to reservoir geology. Marine and Petroleum Geology, 62:161-175. https://doi.org/10.1016/j.marpetgeo.2014.08.025

Zecchin M., Catuneanu O., Caffau M. 2017. High-resolution sequence stratigraphy of clastic shelves V: Criteria to discriminate between stratigraphic sequences and sedimentological cycles. Marine and Petroleum Geology, 85:259-271. https://doi.org/10.1016/j.marpetgeo.2017.05.019 